
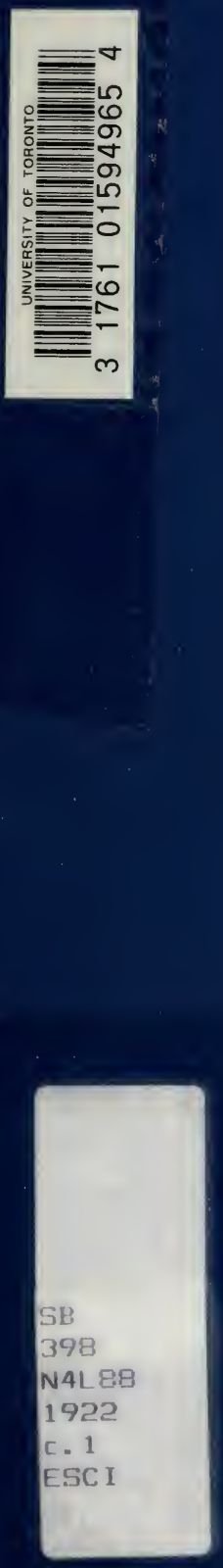
Digitized by the Internet Archive in 2007 with funding from Microsoft Corporation 




\section{vııuULTURE AND BREWING}

IN

\section{THE ANCIENT ORIENT}

BY

H. F. LUTZ
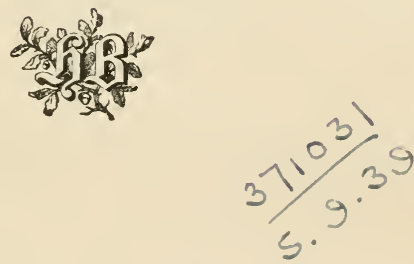

LEIPZIG

J. C. HINRICHS'SCHE BUCHHANDLUNG

1922

Auslieferung für die Vereinigten Staaten von Nord-Amerika:

G. E. STECHERT \& Co.

I5I-I 55 WEST 25TH. ST.

NEW YORK CITY 
Druck von August Pries in Leipzig. 


\section{PROF. DR. ARTHUR UNGNAD \\ UNIVERSITY OF BRESLAU}

THIS VOLUME IS INSCRIBED

IN AFFECTION 



\section{Introduction}

A century ago little was known about the ancient Near East, and that little had been transmitted by unreliable hands; moreover, most of it came from a time which itself was much later than the period in which the ancient Oriental nations played an all-important ròle. Only a few decades ago the whole of Western Asia and Egypt were like an immense field of ruins lying in impenetrable silence, and the little we knew about it came from the pen of a few Greek and Roman writers, who on account of their foreign way of thinking, lack of familiarity with the psychology of the Oriental and their inability to master the Oriental languages were little fitted to become absolutely safe guides. They understood only that which was similar to their own culture. The treasures of Babylonia, Assyria, Asia Ninor, Syria and Arabia had been hidden away by fate; and Egypt had already undergone a process of decay when the Greeks entered that country and wrote down their cursory notices about the land and its people. There were only fragments - miserable fragments - by which posterity could behold the ancient world.

The darkness has been lifted, thanks to untiring work of Oriental scholars in Europe and America, who have worked feverishly during the last few decades. The day has dawned over the Orient, but though the morning-sun has appeared, it very often hides itself behind dark clouds. Some of these clouds will undoubtedly be dispelled by later researches and it will depend on the results of future excavations whether the sun will reach its zenith at least in so far as the cultureland of the Euphriates and Tigris rivers is concerned. Egypt, it seens, has now yielded up most of its treasures. 
The following pages purport to place together the most important, but by no means the entire, material which has come to light regarding the viticulture and brewing in the ancient Orient, material which to a large degree can at best be found only isolated in the respective literatures. To some whom the Orient interests only as a country of religious systems or for purely linguistic or historical questions, the gathering of such materials as contained in this volume will seem banal, but

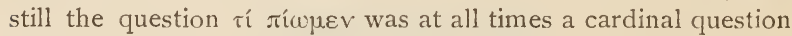
to humanity, and the saying of Pliny "if any one will take the trouble duly to consider the matter, he will find that upon no one subject is the industry of man kept more constantly on the alert than upon the making of wine" is fully verified in our present time. In spite of all modern legislation it is still a question often uppermost in the minds of many peoples whose governments have made tabula rasa with it. And thus it will probably always remain.

The present treatment, which considers the matter from the beginning of historic time down to the wine-prohibition of Muhammed, still contains many gaps, which can be filled only by later discoveries. In many cases our information consists merely of names, for instance, the many beer-and wine-names; and wherever technical details might have been considered more fully, I have avoided such details, as, for instance, in regard to the Old-Babylonian beer recipes; of these we already possess a very elaborate treatment by Hrozný, who has also announced that he will offer another work on the intricate question of the materials used in the Babylonian brewery.

It will, finally, be necessary to say a few words regarding the use of alcoholic beverages by the ancient Orientals. Far be it from me to represent the Orientals to my readers in the light of drunkards. From the testimony of the Classical writers and according to the ideas of some modern scholars it might appear as if they had been such. But this is not the case. In certain circles, it is true, there have existed at all times some debauchers, but history has never seen a whole people absolutely given to drunkenness. Wherever suggestions are to be found which might lead to such a conclusion, they are nothing but strong exaggerations. A sane human intelligence 
has preached at all times and in all climes moderation - and so also in the ancient Orient. The morality of the ancient Near East was, after all, not much inferior to our modern morality, only customs have become more refined. Examples of very lofty ideals are found quite early both in Babylonia and in Egypt.

If the history of mankind should really teach us absolutely nothing, it teaches us at least this one thing, that mankind has by no means kept equal pace in its intellectual and moral development. Even though we may have become wiser, we certainly have not improved very much morally. Therefore we should not sit in judgement over the ancient Orientals, but should rejoice with them in our journey through their world, in which we see them engaged in preparing the precious juice of the grape and in the brewing of beer, in order to gladden their hearts at festivals and to drive away the dull cares of every-day life. Perhaps after the perusal of this book there may arise in the minds of some of its readers the painful thought:

Sic transit gloria mundi! 



\section{Chapter One}

\section{The Wines of the Ancient Orient}

The vine is a prehistoric plant. As such it is very diffcult to determine the country of its origin. It is generally maintained that the wooded regions which extend from Turkestan and the Caucasus to the mountains of Trace are to be considered the homeland of the vitis vinifera ${ }^{1}$. When the dark mist that envelops the prehistoric age passes away, and we find ourselves at the beginning of historic times, the vitis ainifera occupies such an extended area, that it is impossible to ascribe to the plant any special country as its place of origin. The Classical writers mention quite a number of places as having originated the vine, but this merely indicates the very ancient extension of the plant in Mediterranean countries, where the conditions of the soil and the climate were and still are most favorable for its culture. Athen. XV, $675^{\mathrm{a}}$ names the countries about the Red Sea as its place of origin; Ach. Tat. II, 2 mentions Tyre; Hellanic. Fragm. hist. gr. I, p. 67 Egypt; Pausan. IX, 25, 1 Boeotia; Theopomp. Fragm. hist. gr. Car. Mueller I, 328 Chios; and Hecat. I, 26 Etolia. It is quite possible to think of a spontaneous growth in many regions ${ }^{2}$ in view of its wide spread in the earliest historic times.

1) Grisebach, Die I'egetation der Erde, 1, p. 323: Köppen, Geogr. Verbreitung der Holzgeäächse des europäischen Russlands und des Kaukasw;, I, p. 97; De Candolle, Orig. des plantes cultivies; p. 153; Schrader, Tier- und Pflanzengeogr, p. 27.

2) Regarding the soil favorable to the culture of vine see Theophr. Cals. plo, II, 4, 4. For references in Classical writers to wild-growing vine see Pliny, $N$. h. XXIII, 13-14, Strabo XV, I, 58 and Diod. III, 62, 4. On wildgrowing vine (four to five kinds) in Middle- and Northern Syria see ZDPI, $\mathrm{XI}$, p. 161 .

Lutz, Viticulture and Brewing. 
The culture of the grapevine started very early in Egypt ${ }^{1}$. We learn that during the time of the Thinitic rulers, and even in pre-dynastic Egypt, vineyards had been planted for the purpose of providing funerary wines for the early rulers of Egypt ${ }^{2}$. Viticulture seems to have been particularly engaged in during the time of the IV., V., XII., XVII. and XVIII. to XIX. dynasty, judging from the pictorial representations of those periods, which refer to viticulture, vintage and the making of wine.

The best vineyards of Egypt were situated in the Delta and the country not far south of it. The oldest vineyards had been planted in the vicinity of Memphis. South of the Delta the wine produced particularly in the Arsinoitic nomos (i. e., modern Fayyûm) was renowned. The capital of the Arsenoite nome was Crocodilopolis-Arsinoë, Egyptian Shedet. Modern Kîmân Fâris, "the riders' hills", mark the side of the ancient city. Regarding the Arsinoite nome Strabo XVII, $\mathrm{i}, 35$ (C 808) says "It produces wine in abundance". This contradicts Herodotus' statement (II, 77), where he says of

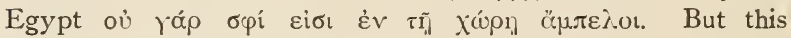
author contradicts also his own words. In II, 42 and 144 Osiris is considered to be Dionysos. In II, 60 he narrates the journeys to Bubastis, where all Egypt gets drunk with wine, and when more wine is drunk than during all the rest of the year. Again he states that every man of the body-guard receives four cups of wine (II, 168). In II, 133 he mentions the drinker Mykerinos and in II, 37 he states that even priests drink wine. Finally in II, 121 he mentions the chief-mason's son, who made the guards drunk with wine. Athenaeus found pleasure in the Mareotic wine. The grape, according to him was remarkable for its sweetness. The wine is thus described by him: "Its color is white, its quality excellent, and it is sweet and light, with a fragrant bouquet; it is by no means astringent, nor does it affect the head" (Virg. Georg. II, 91). The grape was white and grew in a rich

I) For an indication of viticulture in Nubia in predynastic times may be taken the grape-seeds that were found in the stomach of the Nubians. Cf. Bull. Nub. 2. 55 grape-seeds together with melon-seeds and barley husks.

2) See Chapter II. 
soil, principally composed of gravel. Strabo ${ }^{1}$ ascribed to the Mareotic wine the merit of keeping well to a great age. It was even exported to Rome and enjoyed by those who were used to the much heavier Italian wines ${ }^{2}$. Horace, Od. I, 37 mentions it as a favorite beverage of Cleopatra. The town from which the wine received its name, Marea (Mapé $\alpha$; Steph.

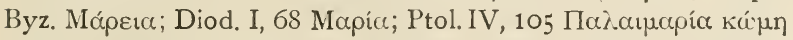
is the Egyptian Pa-mer, the capital of the autonomous district Pa-mer-ti ( Marea owes its name to that of a companion of Dionysos, who was named Maron. The town (now called Maryûț) stood on a peninsula south of Lake Mareotis. It was adjacent to the mouth of the canal which connected Lake Mareotis with the Canopic arm of the Nile. Superior to the Mareotic wine was the Teniotic wine, at least in the estimation of some writers. "Still, however," says Athenaeus, "it is inferior to the Teniotic, a wine which receives its name from a place called Tenia ${ }^{3}$, where it is produced. Its color is pale and white and there is such a degree of richness in it, that when mixed with water, it seems gradually to be diluted, much in the same way as Attic honey, when a liquid is poured into it; and besides the agreeable flavor of the wine, its fragrance is so delightful as to render it perfectly aromatic, and it has the property of being slightly astringent". Athenaeus mentions the Plinthinic wines. He states, on the authority of Hellanicus, that the vine was first cultivated about Plinthine, and to which circumstance Dion attributes the love of wine amongst the Egyptians (Lib. I, 25).

The Sebennyticum was another renowned Egyptian wine. Pliny ${ }^{4}$, in fact, cites it among the best of foreign wines. It is "the produce of three varieties of grape of the very highest quality, known as the Thasian, the aethalus (i. e., the 'smoky'

1) Strabo XVII, p. 799 .

2) See, however, Columella (R. R. III, 2), who states that it was too thin for Italian palates, accustomed to the stronger Falernian.

3) Rather so called from a long narrow sandy ridge ( $\tau \alpha$ ivi $\alpha$ ) near the Western extremity of the Delta.

4) Pliny XIV, 7 . 
grape) and the peuce (i. e., the 'pitchy' grape)". The Thasian grape is de:cribed by the same writer ${ }^{1}$ as such which excels all other grapes in Egypt in sweetness and as having remarkable medicinal properties. Sebennytos (modern Samanûd), Egyptian Zeb-ruter, Coptic Jemnuti, was situated on the Damietta arm of the Nile. Athenaeus praises the wine of Anthylla. "There are many other vineyards in the valley of the Nile," he says, "whose wines are in great repute and these differ both in color and taste, but that which is produced about Anthylla ${ }^{2}$ is preferred to all the rest". Less favorably spoken of is the ecboladic wine ${ }^{3}$. According to Pliny (XIV, 18) it was possessed of the singular property of producing miscarriage (XIV, 9; XIV, 22). It is possible that to the Egyptians it was a particularly strong wine, and as such only drunk by men. This, we may conjecture, may have been the reason for Pliny to make this statement, since he probably saw the Egyptian women abstaining from its use. Pliny knows also the wines of Mendes ${ }^{4}$ (modern Tell Roba or Tell al-Kașr at the village of Tmei al-Amdid), which are mentioned again by Horace and Clemens of Alexandria ${ }^{5}$. The Mendesian wine, according to the latter writer seems to have had a sweet flavor. The wine of the Thebaiis was particularly light, especially about Coptos. The wine of the latter city was so thin that it could be easily thrown off. It was "so wholesome", says Athenaeus, "that the invalids might take it without inconvenience even during a fever". Upper Egypt, according to Athen. I, 60 prodluced a poor quality of wines. Viticulture was engaged in as far south as Meroe the ancient capital of Ethiopia since c. 600 B. C., at which time the seat of government was transferred from Napata to that place. The wine of Meroë has been immortalized by Lucian ${ }^{6}$. On the whole

I) Pliny XIV, I8.

2) Anthylla ("A $\vee \vartheta \cup \lambda \lambda \alpha$ ) was a town of considerable size on the Canobic branch of the Nile, some few miles south-east of Alexandria.

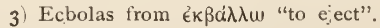

4) See Pliny, Hist. Nat. XIV, 9. Cf- also Athenaeus, Deipnos. I, 30 "Mendaeum vinum coelestia numina meiunt".

5) Paedagog. II, c. 2.

6) Athen. I, p. 33 f; Strabo, XVII, p. 799; etc. Here it may also be mentioned that the story of the shipwrecked sailor, which contains popular ideas 
the Classical writers pass a favorable judgement on the quality of the Egyptian wines. An exception appears to be Martial. This writer considered them all as being of an inferior grade, judging from his statement that the vinegar of Egypt is better than its wine (XIII, 122). Also Apollodorus, the physician, in a treatise on wines, addressed to Ptolemy, king of Egypt, recommended for medicinal purposes foreign wines rather than those of his own country. He praised particularly the Peparthian 1, and the wine of Pontus. This may have been due merely to psychological reasons. The imagination thus was a factor introduced to effect a cure, by the mere prescription of a foreign wine, which was little known in the home country.

The Greek and Roman writers in the last centuries before and after our era laud Egypt also as a country with plenty of wine. We have seen above that the Mareoticum was even exported to Rome, yet it appears that Egypt produced just enough wine for its own home consumption.

The introduction of Islam in Egypt limited the culture of vine to a great extent. In the year $40 \mathrm{I}$ a. H. during the reign of Hâkim many people of Cairo were beaten and led shamefully through the streets of the city, because they had sold wine, amongst other forbidden merchandise. In 402 a. $\mathrm{H}$. Hakkim prohibited the sale of raisins, and issued orders against their importation. A large quantity of raisins was thrown into the Nile or burned, while other immense quantities were

regarding the wonderful country of Punt, situated along the African and Asiatic coasts of the Gulf of Aden, does not fail to give reference to viticulture in that country (lines 47 and 48 ). In the country of the Niam-niam, on his journey from Marra to the bill of Gumango, Dr. Schweinfurth "had time to explore the magnificent vegetation of the adjacent hills. The wild wine (vitis Schimperi) was loaded with its ripe clusters and afforded me a refreshment to which I had been long unaccustomed. These grapes were less juicy than those that grow upon the vine-clad hills of Europe, and they left a somewhat harsh sensation upon the palate; but altogether, and especially in colour, they reminded me of our own growth" (Schweinfurth, The Heart of Africa, 2 nd Engl. edition, Vol, II, pp. 234 and 235).

I) Pliny, XIV, 7. Some scholars read Praeparentium. Preparethos was one of the Cyclades, famous for its wines (Ovid. Met., VII, 470). 
thrown into the streets and trodden down. The vineyards of Gîzah were cut down and orders promulgated everywhere to do the same all over the country ${ }^{1}$. In Miniet ibn al-Khașib (منية ابن الخصيب) vine was cultivated in Idrisî's time.

The travelers who visited Egypt in the Middle Ages have little to say regarding its wines. Hans Jacob Breuning von und zu Buchenbach visited Egypt in 1579 . He says that Egypt has no wine, but for the sake of pleasure some vines have been planted occasionally in the gardens ${ }^{2}$. Pater Wansleben who on June 30 , of 1672 , went by boat from Rashid (Rosette) up-stream, met with an occurance which shows how strictly the Mohammedan Turks prohibited the use of wine. Some young Turkish sailors discovered that the pater had a supply of wine which he had brought with him from Marseilles. They became infuriated and wanted to throw the wine bottles into the Nile ${ }^{3}$. L. F. Norden narrates that he received plenty of coffee and grapes on his journey through Egypt and Nubia in the year of 1737. These grapes were indeed small, but of an excellent taste ${ }^{4}$. Savary ${ }^{5}$ in his description of the old Arsinoitic nomos shows that the Copts at that time still cultivated the vineyards of their ancestors and that they gathered excellent grapes from which they prepared a white wine of agreeable taste. Maillet ${ }^{6}$ who wrote a few decades earlier remarks that most of the Egyptian vineyards are situated in the Fayyûm. He notes also that the Egyptians esteemed the leaves of the grape-vine much more highly than the fruit itself. They were accustomed to wrap chopped meat with these vine-leaves and to cook the whole to a tasty dish. Jomard ${ }^{7}$ again mentions the vineyards of the

1) S. de Sacy, Chrest. Arab. I, p. Tr, 1.-

2) Orientalische Reysz desz Edlen und vesten Hansz 'Fakob Breuning von und zu Bouchenbach etc. Printed at Strassburg by Johann Carolus, 1672, p. 156. Quoted from Wönig, Die Pfanzen im alten Aegypten, I886, p. 254.

3) Relazione dello stato presente dell Ezitto, Perigi, I677, p. 59. Quoted from Wönig, o. c., p. 26r.

4) See Wönig, o. c.

5) Lettres sur l'Égypte, II L. troisième, 1777. Quoted from Wönig, o. c.

6) Rescription de l'Égypte, 1740, L. XI; quoted from Wönig, o. c.

7) Description de l'Égypte, Edit. II, Tom. IV, p. 439; quoted from Wönig, o. c. 
Fayyûm. According to him, however, vineyards are not to be found elsewhere in Egypt.

The oldest Egyptian inscriptions refer to different kinds of wine. They distinguish between white wine, $4 \vec{\square}-\infty]$ and red wine, $4 \vec{\square}$ Besides the most common word for wine $4 \underset{\square}{\square} \delta$, there appear other designations for it 2 . In the inscriptions of Edfu appears the name $s^{3}$, 10$] 0$,

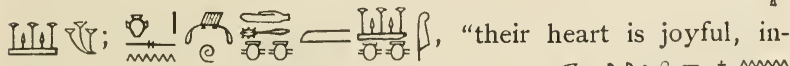
toxicated with genuine wine". Dend. Mar.

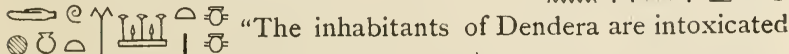
from wine". S3ize (Medic. Pap. 4, 3) refers probably to a special kind of wine. A certain wine produced in the great oasis ${ }^{3}$ bore the name "The green Horus-eye", 1 I. A sacrificial stone which was found in Pompeii and which is referred to king Psammetichos II. refers to this wine. It reads: $94 \sum_{0}$ (口ी छ) ib-r'-nfr-ib-r') has come to thee, O Atum, lord of On; he has offered unto thee the (produce of the) Horus-eye. It has honored thee, O Atum, lord of On, the son of the sun, Psammetichos, by (presenting) the double-jars". Regarding the winecellar in Esna it is written in one of its texts

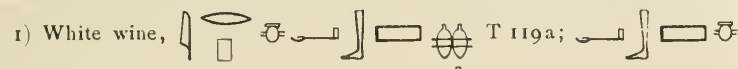
N 456a; Trrga; W r 48a has the reading $\square=$; comp. 'š-beer. White wine seems to have been preferred by the Egyptians to the red wine.

2) 'I $r p$ occurs as a geographic designation in LD II, 46, 47, 50a: Mariette, Mastabas, p. $185,3254 \underset{\square}{\longrightarrow}$, i. c., "the wine domain".

3) See Aeg. Z., 1868, p. 85 ff.

4) Esna (اسناسl) was renowned for its grapes in the days of Idrisî. They 


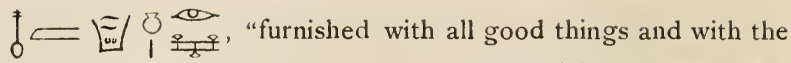
produce of the Horus-eye (i. e., wine)". Dümichen, Hist. Inschr.,

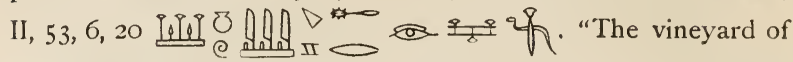
Sohet has (the produce of) the green Horus-eye". This passage and that of Düm., Hist. Inschr., II, 53, b, 18 I.A. If mmoo pes $^{1}$, the produce of the 'Horus-eye' is wine", makes it certain that the "green Horus-eye" designates a wine and not another intoxicating drink ${ }^{2}$. The 'green Horus-eye' was a product of Ombos I. 112:

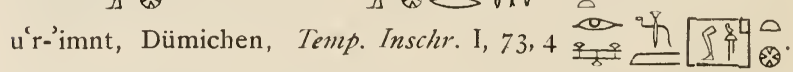
According to Düm. Kal. Inschr. Tafel 109 it causes good

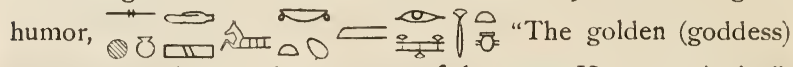
became good-humored on account of the 'green Horus-eye'-wine".

On the stele of Khabiousokari, in the Museum of Cairo ", a certain wine is called $k 3 y, \Delta 34$. The same stele mentions also a wine named irp-w3, $4 \sum_{\square} 6$. Another brand of wine is met with under the designation $\dot{s} d w-i b,\{\sim 8]$ which probably means either "satisfying beverage", or, "thirst-

grew there in such abundance and such superior quality, that they were dried and shipped all over Egypt (Jaubert, Géo. d'Idrisi, p. I28).

I) See also Mar. Dend. I, I7, 21: "He brings to thee the fertile field, bearing grapes (and) the Horus-eye wine - pure things, which thou drinkest (and) which gladden thy heart and cause joy to overflow in thee". Wns = grapes, not coriander (Loret, V. in R. T. XV, I05 ff.). Maspero, Ét. Ég. I, 233: "My clusters of grapes (2)

2) The "white Horus-eye", $\frac{\cos }{0} 90$ is milk. The "green Horuseye" is probably a spiced wine, judging from an inscription in Esna.

3) See Weil, Raymond, Des monuments et de l'histoire des ITe et III dynasties égyptiennes, Paris, 1908, p. 25 I. 
quenching beverage" 1 . Whether the beverage called $s$ bb.t, [1] $\iint_{x \mid 1}^{\square \delta}$ is a wine-brand remains doubtful. The same doubt exists as to h3wh.t, 8 . Since it is found in one passage ${ }^{2}$ together with th, $\circlearrowright$, "intoxicating beverage", i. e., wine, it is doubtless a drink, either a special brand of beer or wine, and it is not the name of a special drinking-vessel. The inscriptions further mention the mn-wine, щ † dark wine. In Pap. Anast., IV, 12, 11 a Semitic loanword occurs which refers to the wine-must as it comes from the wine-press. The word is tinrekw, $]_{1}, 1<0$ in named together with irpac, $\underset{\square}{\longrightarrow} e_{\|=}^{: 0}$ " "wines", sthw, wine" and dhw, $\longrightarrow$ of fig-wine ${ }^{3}$. Ti(n)rkw is derived

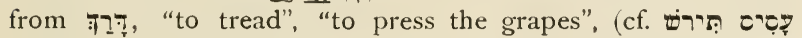

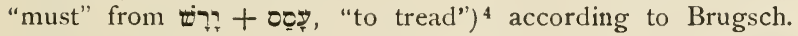
Loret (in Rec. trav. XV, p. $105 \mathrm{ff}$.) considers $]_{1}^{m m} \sum_{0=0}^{\infty}$

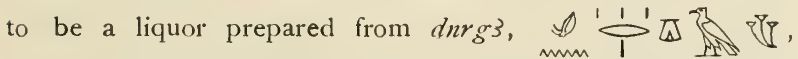
the fruit of which, according to Pap. Anast. III, 2, 3-4, has

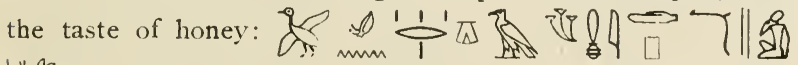
iffor. He furthermore identifies the plant with the carob, stating "en Égypte, et dans d'autres pays on fait encore de

I) Tि8 5 mentioned for the flrst time on the stele of Tetiankhni, in the Museum of Liverpool. See Maspero, Histoire, I (1895), p. 250; Gatty, Catalogue of the Maver Collection; 1. Egyptian Antiquities, No. 294, and Weil, o. c., P. 240.

2) In Dend. Mar. Hathor is called $\square$ i. $\epsilon .$, "the mistress of intoxicating drinks, the lady of h3wh.t".

3) On $k_{3} b$, "fig-wine" see below p. 18. Written $\Longrightarrow \iint$ in Pyr.

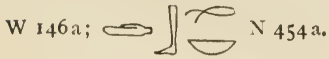

4) See Brugsch, $I V B$, s. v. 
nos jours une boisson rafraichissante avec le suc de Caroube mêlé à de l'eau ou à d'autres liquides". We may finally mention the wine 00 prepared either from the sap or the fruit of the 43 tree.

Besides these different designations for the word "wine" of which irp, 4.0 is by far the most common ${ }^{1}$, the wines or their special brands, are also named according to their places of origin. Through these geographic attributes we are enabled to locate the most important vine-growing districts of Egypt. The Pyramid texts mention the "wine of Lower Egypt" 2. Another wine is called irp rs, "wine of UpperEgypt". Most of the place-names refer naturally to places or districts situated in the Delta. Important is an inscription at Esna for the enumeration of different kinds of wine. This inscription has the following passage $\frac{1}{\square-1}$ याँ

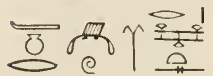

"The produce of Pelusium(?), of Hat-sehaHor ${ }^{3}$, together with (that of) the oasis Kenem, and the produce of the oasis Dsds. (Whenever) the delivery occurs, then appears hearty joy and drunkeness in it, and they intoxicate themselves totally in its district". In the tomb of Ptah-Hotep at Saqqâra mention is made of three of the most important II, 39]

1) This word is preserved in Greek in a verse of Sappho [Athen. Deipn.

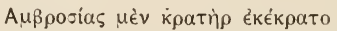

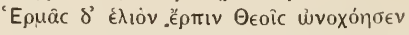

A general name for wine, used less frequently than irp is $3 . t$ Is] 10 ,

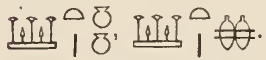
passim.

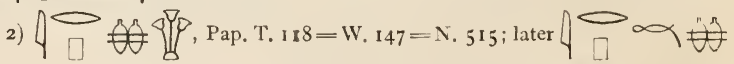

3) The most westernly city of the Libyan nomos. See below p. I2, note $\mathbf{I}$.

4) Düm. Result. XIII, 7 . 
wines of Ancient Egypt, i. e., imp im.t, $4\left[\begin{array}{l}\square \\ \square\end{array}\right.$

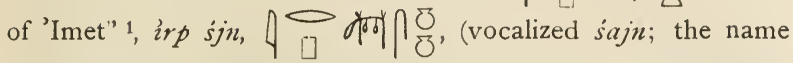
is mentioned in the Old Testament, Ezek. XXX, $15 \% 0$, Sept. $\Sigma \alpha(v)^{2}$ "wine of Pelusium", and irp him $4 \square$ y.j of the fishermen-village" 3 .

I) 'Imt $($ Yemet $)=$ modern Nebesheh, about 8 miles to the S. E. of Tanis and 9 miles to the N. W. of aṣ-Ṣallihîyeh. The wine of Nebesheh is mentioned in Pyr. T I 20a; W 149a; N 457 a; for 80 Beni Hasan I, pl. I7: Q

Ptaḥhotep (see above; cf. Hawara, reprod. Petrie, Hist. I, fig. IIo); $\sqsubset$ II Aby$\operatorname{dos} 1,337 ; \widetilde{I}$ Pieret II, 3I (26. Dyn.) and $\widetilde{D}$ cf. BHI, 23; for tymology

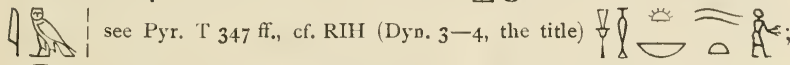

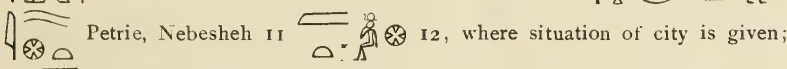
4 मी वी है 16.

2) Spiegelberg, in Aeg. Z., 49, p. 8 I has shown that the city of Sajn, written 120 in the demot. pap. Cairo $31169,3,26$ is identical with Pelusium. Spiegelberg ad $l$. gives also the different writings of the place as contained in the old winelists, i. e., $\bar{\Xi}$ (Cairo, I693); $\bar{\Xi}$ (L. D. II, 67);

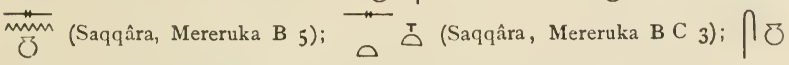
Papyr. 92 Kagemui-Saqqâra); $\int \frac{\Xi}{\circlearrowright}$ (Düm. Result. XIII, $6=$ Ptaḥ-ḥotep, ed Davies, I, pl, 3o). In the same article Spiegelberg also established the reading of that name as śjn, (vocalized $S_{a j n}$ ). See p. 83 of the Aeg. Z. In Ashurbanipal, Cylinder A, Col. i, line $93 S_{j n} n$ is written alu Si- $^{\prime}{ }^{-}-n u$, which makes the vocalization Sajn doubtiul. The Assyrian text, however, confirms Spiegelberg's identification of Śjn with Pelusium. The vicinity of Pelusium appears to have been most noted also for its beers; see below p. 76. For wine of Sajn in the Pyramid Texts see T I22a; W I5Ia and N 459 a.

3) $\int H m$, name of a locality of Lower Egypt (near Lake Mareotis?). 
A territory is several times mentioned in the texts, renowned for its wines, i. e., $s_{3}$ imn, of Amon". This is the name given in the lists of nomes to a territory which belonged to the city of nut-nt-Hapi,

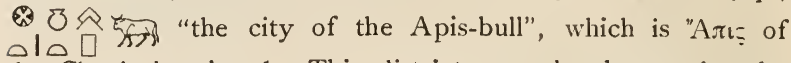
the Classical writers ${ }^{1}$. This district was also known by the name of $33-m n h$. Dend. Mar. says of this district "the vineyard of Mnh has wine", tuated in the third nomos of Lower Egypt, called imn.t that is, the Libyae nomos (Ptolemy IV, $5 \$ 5$ ). Pliny calls the capital of this nome nobilis religione Aegypti locus, and according to Strabo XVII, p. 799 it was 100 stadia distant from Paraetonium. The Libyan nomos was near the Lake Mareotis, renowned for its excellent wines. The banks of a canal or of a lake in this third nome of Lower Egypt, which bore the name ' $n,-\infty$, were planted with vines. An inscription narrates "(the locality of) An bears grapes (and) $\check{s}^{3} 3-m n h$ bears wine" $-\infty$ m Pyramid Texts mention the wine of Nh3mw, $4 \underset{\square}{\square} \mathrm{D}=\mathrm{mm}$ See also Dümichen, Die Oasen der Libyschen Wüste, Tafel $\mathrm{NIX} 4$ ? की दो की

1) The city of Apis of Ptolemy IV, 5, $\$ 5$ seems to refer to the city

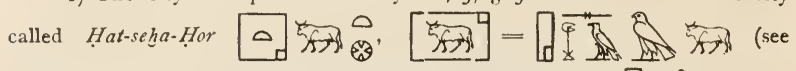
Brugsch, Géo., p. 513), which is identical with Hat-uar-imn.t, $] \gg 0$ The city of Apis to which Herodotus (II, I8) refers can hardly be the same place. On the city of Apis see also above p. 10, note 3 .

2) Mar. Dend. I, 66, 16 \& 8 (m)

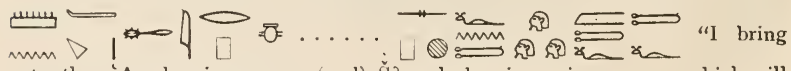
unto thee 'An bearing grapes (and) S3-mnh bearing wine ..... which will cause thy heads to wag". 


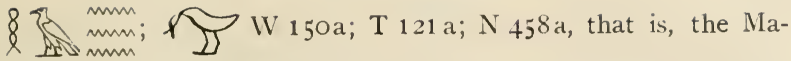
reotic wine.

One of the most renowned vine-districts of Upper Egypt belonged to the city of Diospolis parva, in the seventh nomos. The most famous vineyard of Diospolites was that called $s f t . t$. S St.t is the name of a mountain situated in the seventh nome, according to the investigations of de Rougé 2 . Brugsch later held it possible that the name sft.t may be an oasis of the Libyan desert near al-Khàrgeh but there is no reason why the results of de Rougé's investigations should be doubted. A possible indication of viticulture at Diospolis parva is contained also in the name of a certain district of $H t$-shm, which is called knm.t, "the vine-domain". Brugsch, Dict. Giogr. p. 1345: "Art thou not in Knm.t of Ht-shm (Diospolis parva)?", 4 मी कि min $0\left[\begin{array}{lll}1 & 1\end{array}\right]^{2}$. The oldest reference to the wines of the

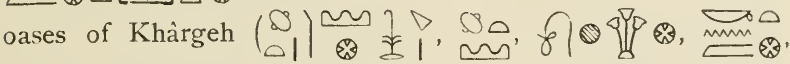

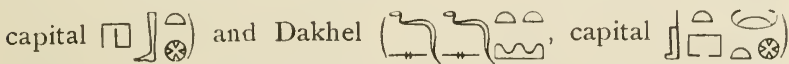
is found in Osorkon's I. record of temple rifts ${ }^{3}$. It reads: „His . . . . . . tribute is (the produce of the oases of) Dakhel and Khàrgeh, consisting in wine and pomegranate-wine; Hemy wine and wine of Pelusium ${ }^{5}$ likewise, in order to maintain ....... his house according to the word thereof". The wine of Khàrgeh was of a very good quality; DGI, Tafel 89 $1.3 \forall$ mm $\delta_{0}$ '

I) Cf. Düm., Kal. Inschr. I03 "the vine-branches of sft.t flourish in their

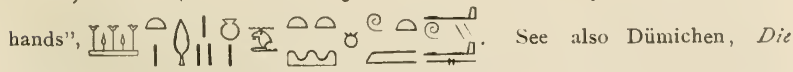
Oasen der Libyschen IVüste, plates XV and XVII.

2) Text. géogr. du temple d'Edfou, p. 83 .

3) See Naville, Bubastis, I, pls. $5 \mathbf{I}$ and 52 .

4) The name of the god is broken away.

5) 1. e., $S_{j n},(S \operatorname{sijn})$. 


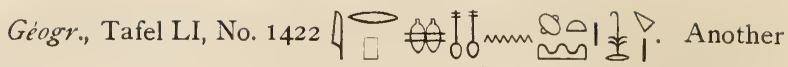
wine-producing district was Tbui, 口 $\leadsto$ and the city of Nham.t, Khârgeh and Dakhel and the cities of Nebesheh and Pelusium 1. The Egyptians received also wine from the oasis called Bahriyeh (the "northern" oasis of the texts) 2. De Rougé, Edfou XXXIX. 4 int reference to viticulture at $\operatorname{Heroo}(\mathrm{n})$ polis, in case that is but a somewhat unusual writing of the name of the city. We have seen above that Athenaeus knew of the wine of Coptos. A reference to the viticulture of that city is found in $\mathrm{J}$. de

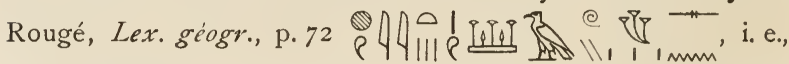
"its riverbanks and its vines". That the vine was cultivated about Coptos is seen particularly from the name of a territory belonging to the fifth nome of Upper-Egypt (the Coptites of the Ancients), which was called ht hsp.t, 0 ( 80 " "the vineterrace". Vineyards were planted in Egypt proper as far south as Elephantine. In the lower country of the first nomos of Upper Egypt, whose capital was Elephantine, we meet with the name of a district, which was called simply "the winedistrict", $4 \underset{\square=}{0}$. The culture of vine at that district, as well as for all parts of Upper-Egypt and the oases, was comparatively late. It is not until the Ptolemaic times that viticulture is actively engaged in about Elephantine.

Vineyards were planted also in the vicinity of Heracleopolis. We have the testimony of an officer of the Saitic pe-

I) "The grapes of $K n m$ (Khârgeh), the produce of $D s \underline{d}$ (Dakhel), the wine of the districts of Tbui, the cities of Neham.t, Im, and Sajn", Dümichen, Die Oasen deriLib. Wiuste, pl. XVI. - The grape, or raisin, of Dakhel appears to have come on the market by the name "Oasis.grape"; see $\mathrm{Br}$., WB., Vol. VII, p. I1 29

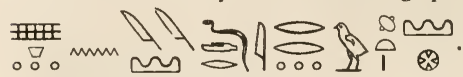

2) See Steindorff, Durch die Libysche Wiiste zur Amonsoase, 1904, p. $144 \mathrm{ff}$. 
riod, called Hor ${ }^{1}$. He states upon his stele that he had planted two vineyards there, in order to provide wine for the god Huneb. Judging from the vineyard scenes in the tomb of Paheri at al-Kab, viticulture was practised also in the vicinity of this ancient city.

One of the most famous vineyards of Egypt was the vineyard of Amon, situated in the Delta near the city of

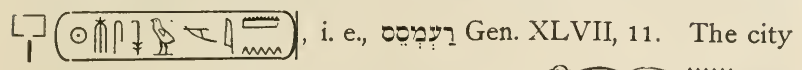
was situated "on the bank of the canal Ptry", " (Pap. Anast. IV, 6, 11) It may possibly be identical with the ancient city of Tanis (Egyptian 说 of the Old Testament; Assyrian case Ptry would be the modern bahr al-Mashrac. The vineyard bore the name $K a-n-k e m e{ }^{2}$. How far this vineyard reaches back in the history of Egypt is not known. But we know that it existed in the time of Ramses II. In the wine-cellars at the Ramesseum have been found many sherds from broken wine-jars, which bear the name of this vineyard ${ }^{3}$. According to Pap. Anast. $3,2,6$ it yielded sweet wine. In Pap. Harris, pl. 8, 1. $5 \mathrm{ff}$. Ramses III. says "I made for it $K a$-n-kemet, inundated like the two lands, in the great lands of olive, bearing vines, (being) surrounded by a wall around them by the iter". King Ramses III. took great interest, it seems, in viticulture. $\mathrm{He}$ paid particular attention to $K a-n$-kemet, but he also extended this interest to distant places. Thus we read in the Papyrus Harris, pl. 7 lines $10 \mathrm{ff}$. "Vineyards I made for thee in the Southern Oasis, and the Northern Oasis likewise without number; others (I planted) in the South with numerous lists. They were multiplied in the Northern country by the hundredthousand. I furnished them with gardeners from the captives of the countries, provided with lakes ......, supplied with lotus flowers, and with pomegranate-wine and wine like draw-

1) See Pierret, Mon. du Louvre, I, p. I4.

2) I. e., "The genius of the Black Land (=Egypt)".

3) See Aeg. Z., 1883, $33 \mathrm{ff}$, and Spiegelberg, Ostraca, pls. 19-34. 
ing water, for the purpose of presenting them for thee in "Victorious Thebes" !

Since the Egyptians were pî̀otvol ${ }^{2}$, i. e., lovers of wine, it is but natural that they expended their genius and their time also on the preparation of all kinds of artificial wines. The home production of grape-wine was never sufficient to meet the home consumption. To meet this deficiency they either imported foreign wines ${ }^{3}$, or else made their own artificial wines. The wine import into Egypt is well attested in the inscriptions. Herodotus III, 6 mentions it. Twice a year a considerable quantity of wine was received from Phoenicia and Greece. In the ruins of Daphnae (modern Tell Defenneh or Tell ad-Daffàneh, ancient $\Longleftrightarrow]\left._{0}^{m m}\right|^{m}$, Hebr. S route between al-Ḳanțara and aș-Șàlihịyeh) wine-jars of distinctly Greek style were found, having been sealed with the seals of Amasis (first half of 6 th cent. B. C.) ${ }^{4}$. These winejars were imported filled with wine. Herodotus also makes the statement that the earthen jars, in which the wine was imported, when emptied, were used for quite a different purpose. They were then collected and sent to Memphis from every part of Egypt and then, after these jars had been filled with water, they were returned to Syria. Amongst the wines imported into Egypt from Phoenicia figure largely those of Tyre ${ }^{5}$ and Laodicea. The caravan-route which the Phoenician wine-merchants travelled led from Gaza through the desert via Raphia, Rhinokorura, Ostracine, past the station at mount Kasius: to Pelusium. The journey from Gaza to mount Kasius took

I) See also Pap. Harris p. 27, 8: "I gave pomegranate-wine and wine as daily offerings, in order to present the land of On in thy splendid and mysterious seat". Cf, also line 9: "I made great gardens for thee, fitted out, containing their groves, bearing pomegranate-wine and wine in the great house of Atum". During the thirty-one years of his reign, Ramses III. bestowed 514 vineyards.

2) Athen. I, 34, b-c. Athenaeus, Deipnos, I, 35 "Dion academicus vinosos ac bibaces Aegyptios esse iniquit".

3) Egypt, according to the Periplus of the Erythraean Sea, 28, exported a little wine into Cana, of the kingdom of Eleazus, the frankincense country
4) See Petrie, Nébesheh, 64 .
5) Heliod. Aethiop. V, 27. 
five days, and thence to Pelusium one day ${ }^{1}$. Since the difficulties in the transportation of wine were great, it was completely lacking in the earliest times; where local production was limited, as in the case of Egypt, they were compelled to make artificial wines. Pliny, XIII, 5 states that in the former times figs, pomegranates, the myxa ${ }^{2}$ and other fruits were used in Egypt in the preparation of artificial wines. Datewine ${ }^{3}$ appears to have been a favorite beverage, according to Pliny (XIV, 19) and Dioscorides $(\mathrm{V}, 4)$, who tell us that this wine was greatly esteemed. Two modes of making this wine seem to have been in use. The Egyptians either scratched the stem of the datepalm with a sharp knife, and gathered the sap into jars and let it ferment, or else they pressed the fresh dates, and the juice thus gained was brought to fermentation. The first method produced a wine which spoiled within a few hours, while by the other method the wine could be kept for a considerable period. Datewine, which was used also for cleansing the entrails of the dead, formed an excellent and cheap drink for the poorer people 4 . For cheapness it was, perhaps, only surpassed by the barley-beer. According to Xenophon ${ }^{5}$ datewine brought on severe headache ${ }^{6}$. A beverage is frequently named in Egyptian inscriptions, called shedekh,

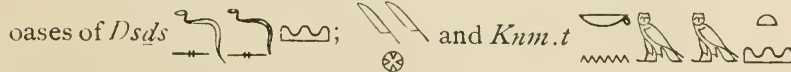

I) Josephus, B. F., IV, I I, 5; Herod. III, 5, 6 and Strabo I, 3, I7.

2) The cordia myxa of Linnaeus.

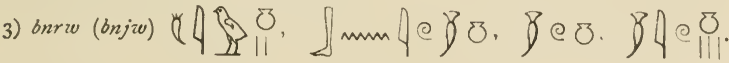

4) Herodotus, II, 86.

5) Cyr. II, 3 .

6) Datewine was used for medicinal purposes. The fruits of the ed-Dom palm, mama. \少, \3, 53 (Hyphaene thebaica Mart. - Cuceifera thebaica Desfon.) were used for making beer. The dates of Egypt were considered delicacies in Rome (Gellius, VII, I6).

7) $\sum_{\nabla \delta}^{\infty}$ in Düm., Kal. Inschr. 120, I. I I ; cf. II9, I, IO; Pap. Anast. I, $5,2-4,7,4$ and often.

Lutz, Viticulture and Brewing. 
produced shedek/ as well as wine ${ }^{1}$. It must have been a very expensive beverage, since in the winelists it generally precedes the name of the grapewine. It is most likely the pomegranate-wine of which Pliny states ${ }^{2}$ that it was in use amongst the Egyptians. A third artificial wine was called baqa, is 8. It was probably made from figs or dates. This wine was imported into Egypt from Palestine ${ }^{3}$. A liquor, made of figs, was called $d b j j \hookrightarrow \int 44 \delta$ (Med. pap. 19, 1), dbjj.t $\Longleftrightarrow \int 400$ (Pap. Anast. 3, 3, 5). See also Pap. Anast. 4, 12, 1. This liquor is compared to a flame, since it burned the throat (Pap. Anast. $3,3,5)$. In regard to fig-wine in the Pyramid Texts see W 146a, T 117 a, N 454a, Pepi II, 1. 154. See also Dümichen, Der Grabpalast, Vol. I, pl. XXV. 1. 95.

Mixed or spiced wines were common in Egypt 4 . The Egyptians mixed or flavored their wines with the juices of rue, hellebore and absinthium ${ }^{5}$. Whether mixed or spiced wines were admissible for use in the religious cult, is unknown, but it is possible, to conjecture that contrary to the practise

I) Dümichen, Kal. 119, 10; Recueil IV, $8_{2}, 5 ; \$_{3}, 7$ etc. In Recueil IV, 79,2 occur the writings

2) Pliny 14, 19; see also Dioscor. 5, 34 .

3) According to Pap. Anast. 3 and 4, Sangar, the mountainious country between the Euphrates and Tigris (modern Sindjar) exported the following beverages to Egypt: qad'auar, kheuaua, nekfet'er and yenbu. The Hittite country, i. e., Northern Syria and Mesopotamia furnished the $\triangle$ ? f $\frac{11}{1} 0$; Sangar furnished the

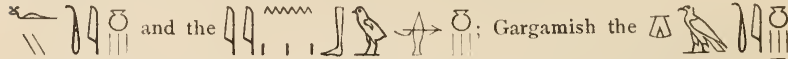
and the country beetween the Orontes and the Balikh (Pap. Anastasi 4, pl. 15, lines 2-4).

4) Of interest is in this connection the popular etymology of the royal name Psammetichus $=p 3-s 3-n-m t k$, "the mixer", that is, he who iuvented mixed drinks. See Spiegelberg, in $O L Z, 1905$, Vol. S, 559 ff. Assyrian: $P$ iša-me-il-ki, Pi-sa-mi-is-ki, Tu-sa-me-il-ki, Tallqvist, Knut, Assyrian Personal Names, pp. ISI, I $\$ 2$.

5) Pliny. XIV, I6. 
of the Hebrews the Egyptians had no religious scruples in presenting as offerings adulterated or even artificial wines. Wine-offerings were made at the common offerings and the offerings of the dead. Wine always heads the list of liquid offerings. In Heliopolis, however, wine did not belong to the offerings, according to Plutarch ${ }^{1}$. He states that the priests brought no wine into the temple and that they considered

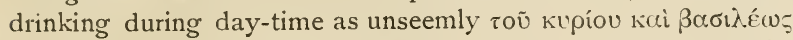

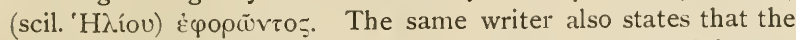
priests abstain from the use of wine only on days of fasting.

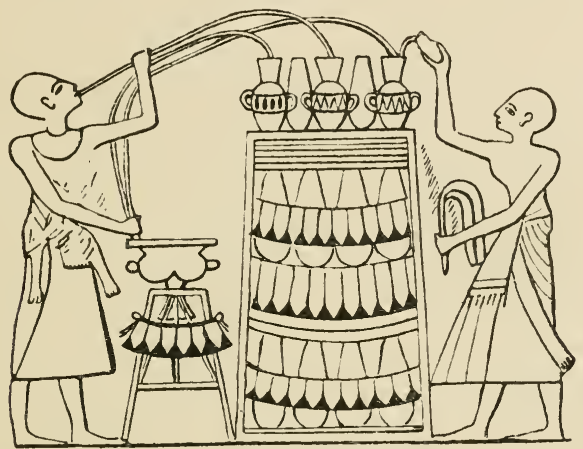

No. I. An Egyptian Siphon (after Wilkinson, The Ancient Egyptians).

For the mixing of wine the Egyptians used the siphon. The process is illustrated on a tomb-painting in Thebes (see Illustration No. 1). A servant is seen directing the wine of three raised wine jars by means of three long siphons into a twohandled wine-cup. Two siphons are represented as being already in action. To exhaust the air the servant has put the end of the third siphon into his mouth. He sucks it, and thus causes the contents of the third jar to flow. Another servant is seen holding two small siphons in his left hand. He stands behind the frame-work and re-fills the slowly emptying jars with a cup.

I) Plut., Is. Chapt. VI. 
The Egyptian monuments of the early time are silent regarding the question of a wine-tax. This, of course, does not imply that there was none such existing. It is rather to be conjectured that the contrary was the case. For the time before the end of the twentieth dynasty we possess testimony that the wine tax was levied and that this tax consisted in kind. That is, the wine tax was paid with wine. In the stele of Bilgai ${ }^{1}$, the Overseer of the Fortress of the Sea, who probably lived in the time of Tewosre, Bilgai boasts in the last section of the inscription of the greatness of the revenues for which he was responsible. His people he assessed to an excess of 25,368 measures of wine. Lines $17 \mathrm{~b}$ ff. read: " 4632 measures of wine was the (assessed) produce of my people. I delivered them as 30000 , an excess of $25,368^{\prime \prime}$. The title of Bilgai "overseer of the Fortress of the Sea" shows that the wine spoken of, was wine produced in the Delta. The wines imported from Syria and Greece were most likely subject to a custom house tax even in the time of the end of the Middle and the beginning of the New Empire. Although the Egyptian records are silent on this matter, yet it seems that the treasury of the State drew no small income from the custom house receipts of foreign wines. In a letter of the king of Alashiya and one of the "râbișu" of Alashiya to the king of Egypt we seem to have an indication that the Egyptian state had its custom-house officials at the Delta-harbors. These letters call the official of the customs amêl pagâri-ka, "the man who makes claim for thee (i. e., the king)". No. 39 lines 17-20 read: a[mê]l pa-ga-ri-ka ulia-ga-ar-ri-ib it-ti-šu-nu, i. e., "Thy custom-house official shall not draw nigh unto them (i. e., my merchants and my ship)". No. 40, lines 24-26: a[mêe $] l u$ an$n u-i \iota$ ardu ša šarri be $[-l i-i a]$ ù amêl $p[a]-g a-r i-k a$ it-ti[ $[-s ̌ u]-n u$ ul i-gi-ri-ib muhhi-šu-nu, i. e. "the men are servants of the king, my lord, and thy custom-house official (who) is with them, shall not draw nigh against them". Merchants and servants of foreign kings thus seem to have enjoyed the privilege of exemption from paying custom-house duties ${ }^{2}$. Under the rule

1) See Gardiner, in Aeg. Z. 50, p. 49 ff. and pl. 4 facing p. $5^{6}$.

2) Knudtzon, Die El-Amarna Tafeln, No. 39 and No, 40. 
of the Ptolemies the winetax seems to have been paid in money ${ }^{1}$. Wilcken, Griechische Ostraka, p. 270, \$86 discusses the winetax of the Roman period, called oivou $\tau \hat{\text { ños. }}$. The tax is levied in the Roman period from the owners of the vineyards, who produce wine ${ }^{2}$. This tax may be viewed either as constituting an assessment placed upon the amount of the produce of wine yielded from the individual vineyards, or as a tax placed on the consumption of wine, which, according to Wilcken, may have been levied indirectly on the producer, in order ultimately to be paid by the consumer. The difference in the quality of the grapes and the wine was seemingly instrumental in the varying amount of the winetax. Theban Ostraca, University of Toronto Studies, 1913, pp. 124-125 gives three wine-tax receipts. No. 88 (G. 280) is as follows: "Tithoes, son of Petosorkon has paid through Horos for the valuation of wine for the tenth year in the Upper toparchy 4 obols. Year 10 of Domitianus our Lord, Hathur 11" (i. e., 90 A. D.). No. 89 (Gr. 7o), dated in $181-2$ A. D. reads: "Miusis and his colleagues, supervisors of the valuation of wine and palms to Pekrichis, son of Pekrichis, son of Heraklas. We have received from you for the valuation of wine of the produce of the twenty-second year eleven dr. 2 obols $=11$ dr., 2 obols, which we will pay into the official bank". The third document dates back to the early third century A. D.: "Aurelios ..... athes, son of Inaros and Plenis, son of Psenenphos, collectors of the valuation of wine and palms of the third year, in respect of Aurelios Pechutes, son of Premtotes, on $1 / 6$ arura $24 \mathrm{dr}$. Year 3, Mesore 8 . Also for the fourth year 8 dr." A custom-house receipt for wine imported upon a donkey is preserved to us in the Tebtunis papyri ${ }^{3}$. It reads "Aurelius Plutammon has paid through the custom-house of Kaine the tax of $1 / 100$ and $1 / 50$ on importing upon one donkey

I) Wilcken, Griechische Ostraka, \$86, No. 327 .

2) The wholesale wine-merchant $=$ o'vé $\mu \pi \circ \rho \circ$, Grenf. II, 61, and Pap.

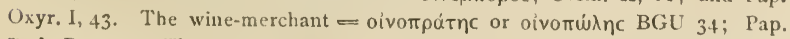

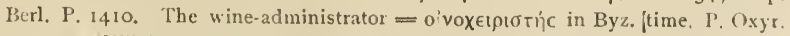
141, 150 Wilcken, o. c., p. 693).

3 Grenfell and Hunt, The Tebtunis Paprri, Part II, No. 362. 
six jars of wine. The fifth year, Phamenoth, the fifth, the fifth"1.

We turn next to the wines of Syria. Syria was the wine country par excellence of the Ancient Near East ${ }^{2}$. Its climate invited the culture of the vine, and the Syrian wines were considered most excellent ${ }^{3}$. We have seen above that together with Greece, Syria supplied Egypt with a considerable quantity of wine ${ }^{4}$. In the tomb of Rekhmare, the Syrians are represented as bringing their wines as tribute. At the time of the XII. Dynasty, a region called Yaa in Syria is mentioned as having more wine than water ${ }^{5}$. Tothmes III. describes the wine in the presses of Daha to have been "like running water", or. "like a stream" 6 . The most famous wine of Syria was, perhaps, that of Chalybon, which was exported from Damascus to Tyre $^{7}$ and into Persia. It was the wine drunk by the Persian kings, and preferred by them to the exclusion of any other kind ${ }^{8}$. The wine of Chalybon is mentioned also in the

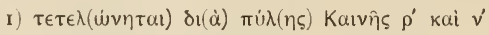

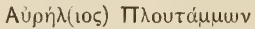

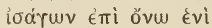

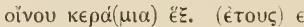

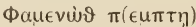

$\epsilon$

2) Pangeum in Syria is considered by Hesychius as one of the many places claiming to be the birth-place of Dionysos.

3) Ezek. 27, 18: Hos, 14, 7 ; Herod. III, 6; Athen., deipn. I; Strabo, geogr. XVI; Pliny, hist. nat. XV, 9.

4) Herod. III, 6; Strabo, geogr. XVII.

5) Tale af Sinuhe: $(\delta \mathbf{r})$ "there were figs $\left(\delta_{2}\right)$ in it and vines, more plentiful than water was its wine". Sinuhe further narrates that following his appointment as sheikh of the tribe by Emuienshi $\left(\delta_{7}\right)$ "I portioned the bread daily and wine $(88)$ for every day".

6) de Rougé, Rev. Arch., I860, p. 297; Lepsius, Auswahl, 12, 5; Sethe, Urkunden IV, 687, lines II-I3. Daha [ זהח ; (?)] is a name generally used in a very vague sense. Partly it correspondents to Syria (and Phoenicia) and partly to the Semitic Canaan. Its meaning cannot be narrowed to that of "Phoenicia". Daha wines, 4 C Pap. med. Berlin XI, r.

7) Ezek. 27, r8; see also Delitzsch, Die Bibel und der Wein, p. I2.

8) Herodotus (I, IS8) narrates that the clear, goodtasting water of the Choaspes formed the ordinary drink of the Persian kings. They used to take 
Cuneiform literature ${ }^{1}$. The wine of Libanios had the odor of incense according to Pliny. He states "The Libanian vine also produces a wine with the smell of frankincense with which they make libations to the gods" 2 . Praiseworthy of mention was also the wine of Apamea. "It is remarkably well adapted for making mulsum ${ }^{3}$, like that of Praetutia in Italy" 4. Elagabulus supplied his horses at Rome with Apamene grapes (Lampr. Elag. 21). An inscription, probably of the fourth century A. D., over the door of a large wine-press near Apamea, refers to the sweetness of the wine in the sunny Orontes valley:

\section{Nectareos succos, Baccheia munera, corniș \\ Quae bitis genuit sup aprico sole refecta}

(CIL III, 188 [Bara]). The district of Damascus which is the paradise of the Orient, mrust have been rich in vineyards and wine. A subtle, although faulty, etymology finds in the name Damascus, דמשי vine. According to Posidonius (in Athenaeus) vines of Chalybon had been transplanted to Damascus. Hieronymus testifies that still at his time Damascene wine was exported to Tyre in his Comment. in Esech. c. 27, p. III, 887: "significat autem, quod inter ceteras negociationes Tyri, ad nundinas eius de Damasco deferebatur vinum pinguissimum et lana praecipua, quod usque hodie cernimus". Famous was the wine of Laodicea ${ }^{5}$. Laodicean wine, according to the Periplus, was imported into Abyssinia, the Somali Coast, East Africa, South Arabia and India. Ibn Batuta I, p. 152 praises the vineyards of Aleppo. According to Strabo Laodicea "is a very well-built city, with a good harbor; the territory, besides its fertility in

along whole wagon-loads of this water in rẹssels of silver. For this reason

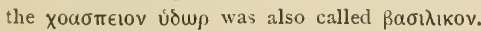

I) See below P. 43, note 2 .

2) Pliny, XIV, 22, 2. Cf. Hosea 14,7 revised version "the scent thereof

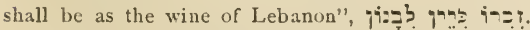

3) I. e., honeyed wine. Either honey mixed with must or grape-juice, or honey mixed with fermented wine. To both kinds the name mulsum is applied. For a reference to the wine of Apamea, see also Waddington, Insc. d'As. Min. n. 2644.
4) I'liny, XIV, 9.
5) Alexand. Trall, II. p. 483 ; Strabo, XVI, 75 I. 
other respects, abounds with wine, of which the greater part is exported to Alexandria. The whole mountain overhanging the city is planted almost to its summit with vines". The country of Alashiya, 4 \& Pap. Anast. IV, pl. 15, line 2, furnished a liquor which was

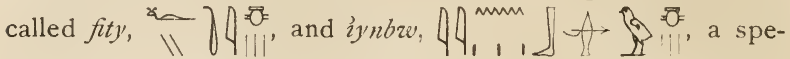
cial kind of grape-wine (see E. de Rougé, Mémoirt sur la propagation, p. 97 is). In Nàsir-i-Khusran's Diary of a Journey through Syria and Palestine ${ }^{1}$ mention is made of the grapes of Ma'arrah an Nu'nân, southwest of Qinnasrin: "There are here also fig-trees and olives, and pistachios and almonds and grapes in plenty". The culture of vine at Ma'arra an Nu'mân is also mentioned by Idrisî. In Pap. Anast., IV $, 15,3$ the name of a certain beverage is given, which came from the country of Amurru, 40 . It is called keny, or also kenny. It is, however, likely that this name does not refer to a certain brand of grape-wine, but that it is a special fruit-juice, or a must'2. 'Amr, Mu'allaqat 7 mentions the wines of Baalbek and Qasirin. Idrisî refers to the fact that the vineyards of Baalbec produce more grapes than the people need for home-consumption. Strabo ${ }^{3}$ mentions the wine of Seleucia. Good wine was grown in the Syrian Androna, which exported it to Arabia!. Hassân ibn Thâbit mentions the wine of Bait Ras. The wine of al-Khuss in the neighborhood of Qàdesia. is mentioned in Imruulqais XVII, 8: "merchants, who go up from al-Khuss with wine, until they discharge it at Yusur". In the Haurân the wines of Sarkhâd and Bosrà enjoyed renown ${ }^{6}$.

I) See Palestine Pilgrims' Text Society, Vol, IV, p. 3. Nâsir-i-Khusran wrote in 1047 A. D.

2) Aeg. Z.. $1877,32 . \quad$ 3) Strabo, VII, $5, \mathrm{~S}$.

4) 'Amr Mu'allaqat I. "Now then, awake, and bring our morning draught from thy goblet, and do not keep the wines of Anderein".

5) Ibn Hishâm, ed. Wüstenfeld, 829, v. 4. Yâqût knows of two localities of that name, one at the Jordan, the other near Aleppo. Both possessed vineyards.

6) Hạâsa, 646; Kitâb al-'agînì XI, 87,7 and Yâqût III, $3^{\text {So. }}$ 
We read in Num. XX, 5 that the Hebrews regretted to leave behind the wines of Egypt, at the time of their departure. Yet Palestine was a country richly blessed with vineyards long before the Hebrews arrived. This is attested even in the Old Testament 1 . Wine, indeed, was one of the chief products of the land ${ }^{2}$. It is probable that the proper rendering of the expression "A land flowing with milk and honey" (Ex. 3, 8) should be: "A land flowing with leben ${ }^{3}$ (i. e., sour milk and dibs (i. e., grape-syrup)". The words are equivalent to "a land abounding in flocks and thickly planted with fruitful vineyards". The grapes of the vicinity of Hebron were particularly renowned. Nàsir-i-Khusran" says: "From the Holy City to Hebron is six leagues, and the road runs towards the south. Along the way are many villages with gardens and cultivated fields. Such trees as need little water, as for example the vine and the fig, the olive and the sumach, grow here abundantly, and of their own accord". A number of place-names bear witness to viticulture. A valley near Hebron bears the

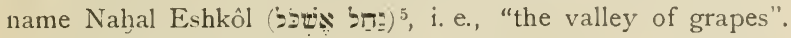
South-west of Hebron, in the mountain of Judah, lay the city

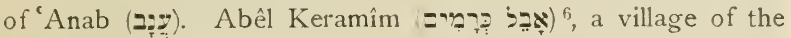
Ammonites, was still rich in rineyards at Eusebius' time, according to Onomastica sacra, ed. Lagarde, 225, 6. Bêth

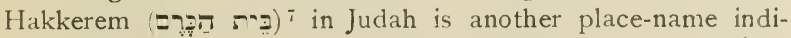
cating the culture of vine. MNidda $1,7, \mathrm{~T} 3,11, \mathrm{~b} 20 \mathrm{a}$ biq'ath

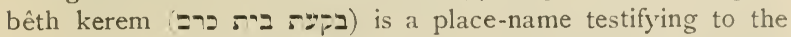
culture of vine in the plain. The plain of Sharon, and farther south the old country of the Philistines, were renowned winedistricts in Rabbinic times until the beginning of the Middle-

I) Num. XIII, 24, The Hebrew tradition (Gen, 9, 20) saw in Noal the originator of viticulture. The variety of grapes in ancient times, as now, was very great in Palestine, and each kind had its special use.

2) Dt. 6, II; 7, 13;8, 8; Hos. 2, 10. 14. I7; Jer. 5, I7; 39, 10.

3) Sour milk, according to the Kitâb al-'agiânî VIII, 74 and 75 was con sidered to be food for slaves in Ancient Arabia. C.f. also the Dîan of the Hudhailites, 96, 9; but compare Lebîd XI, 4 .

4) Pal. Pil. T. S.. Vol, IV, pp. 52-53.

5) Nu. 1 $3,23 \mathrm{ff}, ; 22,9 ; 1$ t. $1,24 . \quad 6)$ Jdg. I I, 33.

7) Jer, $6,1:$ Neh. $3,14$. 
Ages. According to the Mishna Qerruchim and Chătulim produced the best grades of wine. Next follow the wines of Bêth Rima and Bêth Laban in the mountain, and Kĕfar Signa in the plain. These places were probably situated in the plain of Sharon. MKil. 6, 5 mentions also the vineyard of Kĕfar 'Azîz (כפר); b Sabb. $147 \mathrm{~b}$ mentions the wine of Perrugitha (พรามาפד saret see Neubauer, Géogr. 45. 215. Solomon possessed a vine-

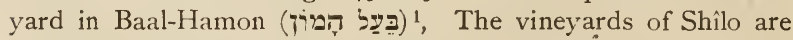
mentioned in Jdg. 21, $19 \mathrm{ff}$. According to II. Chron. 2, 9, 14 the people of Tyre were furnished with Judaean wine during the building operations of the first temple, while at the time of the second temple this wine was furnished to both the people of Tyre and of Sidon 2. Viticulture about the city of Lachish is attested by a representation of the Assyrian king Sennacherib, in which the king is shown seated upon his throne in a hill-country, planted with figtrees and vines (see Illustr. No. 2). In the Inscription of Una lines 24 and 25 we read fumm

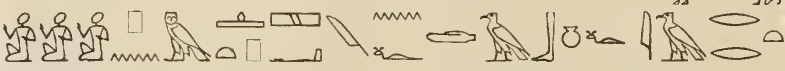
Yoo $x_{a}$ "this army returned in safety (after) it had cut down its figs (and) its vines", referring to the country of the Herusha

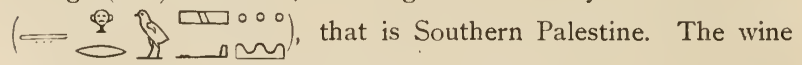
of Haru or Northern Palestine is not infrequently mentioned by the Egyptians ${ }^{3}$.

The wines of Palestine, as well as those of Syria, were very sweet, like syrup. The wine of the plain of Sharon was extremely strong. After it had been mixed in the proportion of $1 / 3$ wine to $2 / 3$ water it still was equal in strength to undiluted Carmel-wine. Different kinds of wines were known to the Hebrews. The Babylonian Talmud ${ }^{4}$ mentions the hilisțon (ipioorov), a sweet and weak new wine.

1) Cant. 8, 11. 2) Esra 3, 7.

3) See for instance Pap. Anast. 3, verso $2 ; 4,16,1$ and Pitomstele 17 $4 \sum_{0} 0 f_{0}$ d

4) Baba Bathra 97 a ff. 
In preparing this wine, the grapes were exposed to the sun for a few days prior to pressing. Another new wine was called "the smoked wine". "Three-leaf" wine (המרא בר תלתא טרפ bSabb 129a) was the name of a wine pressed from the

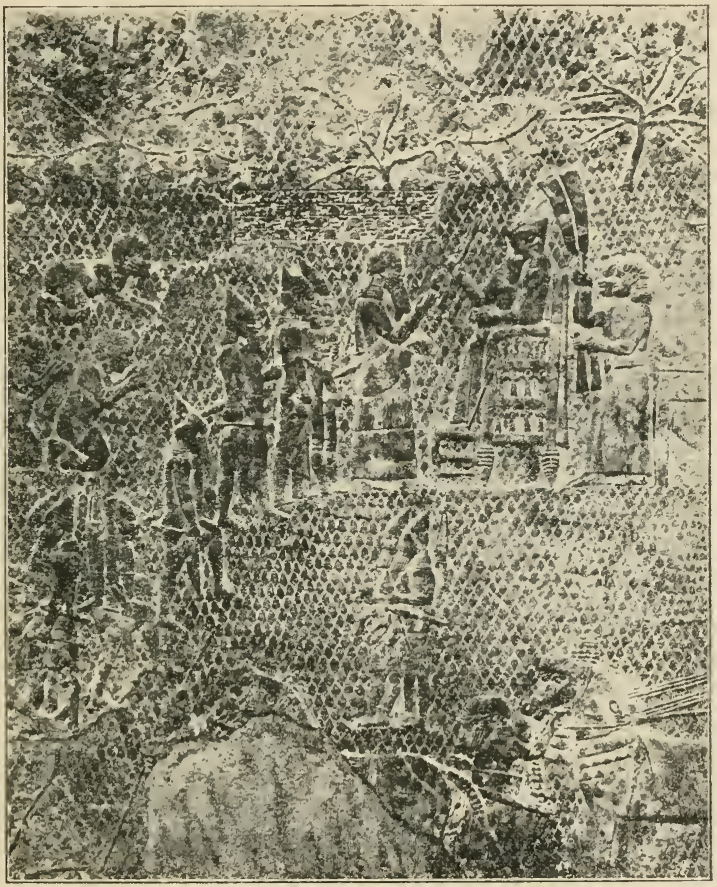

No. 2. Sennacherib before Lachîsh; vine-clad hills in the background (after Gressmann, Altorient. Texte und Filder).

grapes of a vinestalk that had borne leaves for the third time. Simmuqim, i. e., the Psythia or Amminea of the Romans, was the name of a wine prepared from raisins. Küshi was a dark red wine prepared from dark blue grapes. From the grapes 
of the wili-growing vine Thtis labrusca L.) was prepared a wire called $-\cdots:-:$, Greek oiváv $r_{1}$, which seems to have been used more generally for medical purposes ${ }^{1}$. For ritual purposes and day s of festivities unly- Yay was permitted to be used. Tayin was an old, unadultered grape-wine. The custom of mixing the wine: with water seems to have beer first introduced in the Graeco-Roman times?. It was considered a deterioration of the precious and noble juices. So it was cnssidered also in Rabbinic times whenever wine was mixed with honey or spicest. Honey-wine was not known to the ancient Hebrews. It foreign origin is shown by the nomenclature ovoucis, $\because \mathbf{*}: \mathbf{x}$ in the Talmuds. Four parts of wine were used to one part of honey. A second boney-wire, inum condizum, $\cdots-\cdots ;$ was a spiced wine. which received a certain quantity of frankincense

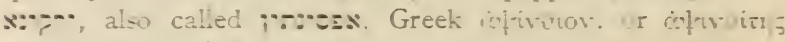
was a bitter-ta-ting herb-wine.

The vineyards of Engedi are mentioned in Cant. cant. I, 14. Felix Fabri, writing about $1480-14 \Omega_{3}$ of our era gives us the foliowing account of the vineyards of Engedi. "Woreover upon these mountains there once stood that exceeding famous vineyard of Engedi, whe-ein grew balsam beyonc all price. This vineyard was planted in this place, Engedi. by King Jolomon. The author of the Speculum Historiale says. by the mouth of Iosephus, that the queen of Sheba. who came to Jerusalem, from the end. of the earth to hearken to the wisdom of Solomon, as is told in I. Kings 10, brought him many preciots jitts, among which was the root of the balsam, as being a gitt beyond all price, which root the king planted on the Mount of Engedi, and it was grown in the vineyard there. This vineyard is mentioned by- Solomon in the Song of Songs. where he says: "My. beloved is like a cluster of camphire in the vineyards of Engedi. This vineyard is now in Egypt, and I shall tell who it was who dug it up and transplanted it, and of the

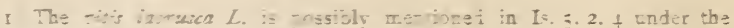
rase zx=

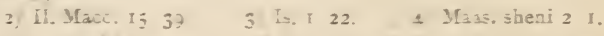

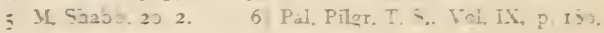


virtues of balsam and camphire, in Part II, p. 68. I have read in an ancient pilgrim's book that some pilgrims to the Holy. Land once wandered over these mountains searching carefully, and that in one place they found shoots of balsam. but no shrubs. Beside balsam there once grew on this mountain an excellent wine, wherewith it is believed that Lot's daughters made their father drunk, as we read in Gen. 19". Burchard of Mount $\operatorname{Sion}^{1}$ (1280 A. D.) praises particularly the wine of Bezek, west of Bethlehem. He writes "Half a league west of Bethlehem is a village called Bezek, which abounds with excellent wine, so that there is no better to be found in the land". The same author mentions also the wines in the Valley of Rephaim, of Sidon, of the Lebanon, of Antaradus and of Margat. Regarding the vineyards of Samaria and Moab see Jud. 9, 12-13. Judging from the rame of the city of Gath I.j. Assyr. Gi-im-tu=Gi-in-tu it appears that viticulture and the making of wine must have been very prominent here as well as in mud, Meg 6 a the country of Naphtali was everywhere covered with fruitful fields and vineyards. In Galilee little wine was produced. and for this reason, it was more greatly esteemed than oil (Nazir, 31 b: אי: Josephus, Wirs, B III, c X, S states that Gennesaret "supplies men with the principal fruits, with grapes and figs continually, during the months in the year".

The Talmud mentions certain wines which were prohibited at a certain period, on account of the fact that these wines were grown in places which were situated near settlements inhabited by Samaritans. Thus Abod. zar. 4: "The wine of Ogdor is forbidden to be drunk on account of the neighborhood of Kèfar Pagesh: that of Borgatha on account of the neighborhood of Birath Sariqah; that of 'Ain-Kushith on account of the neighborhood of Kẽfar Sha'em", --2x := : "

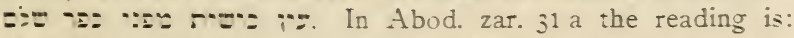
אי" こ:

I) Pal. Pilgr. T. S. Vol. XII pp. Soff. 
The Hebrews ${ }^{1}$ liked to strengthen the wine by adding spices, thus making it more palatable ${ }^{2}$. Wherever the Old Testament speaks of "mixing the wine" 3 , the preparation of such "spiced wines" is meant. Spiced wines were prohibited, however, for ceremonial purposes. Wine mixed with myrrh was considered a narcotic ${ }^{4}$, while amongst the Greeks and the Romans, myrrh-ivine was esteemed as less intoxicating, therefore being favored as a drink for women. The Mishna (Baba Bathra 98a) mentions perfumed wine, which is possibly identical with spiced wine. The Classical writers do not dwell on the discussion of the strictly Palestinian wines. This is undoubtedly due to the fact that much of the wine that was exported from Phoenicia was labelled as Phoenician, or thought to be Phoenician wine by the foreign receivers, whereas it was originally prepared by peoples living in the countries adjacent to Phoenicia.

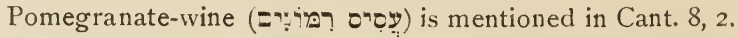
The pomegranate, an apple-shaped red fruit of $5-10 \mathrm{~cm}$ diameter, contains a large number of juicy fruitstones. It was from this juice that pomegranate-wine was prepared. Applewine seems also to have been known to the inhabitants of Palestine ${ }^{5}$. During the time of harvest a sour beverage called rọi (Rt. 2, 14; cf. Ps. 69, 22) was sometimes used. Chômez

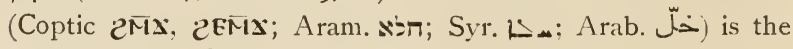
common word for "vinegar", which was custumarily prepared from a poor quality of wine (vimum culpatum). It was considered a refreshing and strengthening beverage even in later

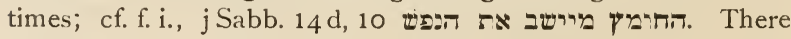
remains some doubt whether the following beverages should be classed with the wines or the beer. According to Rabbinic usage they should be enumerated amongst the beers, but we shall rather follow the Greek and Roman usage and refer to them here. From the fruit of the laurel-tree was prepared

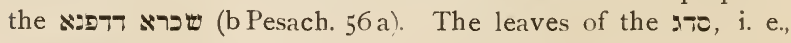

I) All the ancient people were fond of spiced wines.

2) Yavin harekakh; Cant. 8, 2.

3) Is. 5, 22; Ps. 75, 9; Prov. 9, 2. 5 (7ְ). 4) Mk. 15.23.

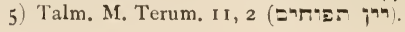


the laurus malabathrum, also were used for making wine. "Brier-wine", שכר של היזמי was a date-wine mixed with cuscuta, which grows on a thorn-bush (היזמי-Similar was the beverage called (See b Kethub. 77 b and b Pesach. 107 a).

Phoenicia also was one of the important wine countries of the Orient. According to Schol. Apoll. Rhod. IV, 540 and 983 it shared the distinction, amongst other countries, to have contained the birthplace (Nysa) of Dionysos. Phoenicia cultivated wine of excellent quality and great quantity. Phoenician wine was exported together with the wines bought in Palestine and Syria and elsewhere. Most of it was shipped to Egypt, but also Arabia, eastern Africa and India were supplied with the famous stocks of the Phoenician wine-merchants. Diod: 5,17 states that the traffic of wine led the Phoenician traders even to Spain and the nearby islands. Wine constituted one of the chief articles of the Phoenician traders and the gain from this export article must have been enormous. Compare f. i., Horace, Od. I, 31, 10: dives et aureis mercator exsiccet culullis vina Syria reparata merce Dis carus ipsis; quippe ter ct quater anno revisens aequor Atlanticum impune. The wine of Tyre is mentioned in Alex. Trall. II, p. 327, 407, 457,485 , and 495 ; Pliny $14,9(7)$. It claimed distinction together with the Syrian Chalybonium ${ }^{1}$. Tyre was richer in beer and wine than in water, for we read in Pap. Anast. 18 that "water is brought to her by ship". An inscription of Heraclea in Lucania ${ }^{2}$, dating from the end of the fourth century B. C., speaks of $\beta v \beta \lambda i \alpha$ and of $\beta v \beta i$ iv $\alpha \mu \alpha \sigma x i \lambda \alpha$ which has probably reference to the viticulture of Byblos. The Bißivos oivo $\xi$ is, at least in some instances, understood to be a wine, which came from the Phoenician city of Byblos ${ }^{3}$. The vinestalk of Byblos was planted in Luciana as well as in Sicily ${ }^{4}$

I) The Chalybonium came originally from Beroea, but afterwards grew also in the neighborhood of Damascus. For this wine see Pliny, Hist. n. XIV, 73; Geop. 2, and Athen. I. p. 28 d.

2) CIG III, 5774 lines $5^{8}$ and 92 .

3) Byblos, i. e., Gŭbĕl, Arabic el-Kobyle, modern Djibeil; Jo. Phokas $\Longrightarrow Z \in \beta \in \lambda \epsilon \tau$.

4) It is stated that a certain king $\Pi \delta \lambda_{\lambda} \backslash \varsigma$ of Sikyon or Syracuse, or else an Argeian called $\Pi$ ó $\downarrow$ toc (Poll. VI, 16) brought the plant to Sicily. The 
and some other places ${ }^{1}$. All the wines made from the original Byblos vine-stalk were called $\beta i \beta \lambda$ เvos oivoç. Not every Bi $\beta \lambda$ ivos oivos, therefore, was a wine of Phoenicia. The

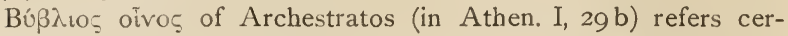
tainly to the wine of the Phoenician city. The wine of Sarepta is mentioned in Alexand. Trall. I, p. 335.483; II, p. 217.325, and 407; and in Sid. Apoll., Carm. 17, 16. Pliny (XIV, $9(7)$ ) mentions the wine of Berytos ${ }^{2}$, and the wine of Tripolis (XIV, 9(7)). Idrisî also mentions the vineyards of that city. Regarding the viticulture of Homs he states that this city possessed many vineyards at the time of the Muhammedan possession, that is prior to the Crusades, but that they are now nearly completely destroyed. The wine of the country of Arvad is mentioned in an Egyptian inscription ${ }^{3}$. For the wine of Gaza see Sid. Apoll., Carm. 17, 15 and Isid. Orig. XX, 3, 7. Gaza was the center of the wine-trade for Egypt and Syria. This city had built up a considerable industry in the manufacture of wine-jars for the export trade ${ }^{4}$. The harbor of Gaza, called Maioumas, contained a colony of wine dealers ${ }^{3}$. Mention is made of the wine of Gaza also in the Code of Justinian, together with the other famous wines of that time ${ }^{6}$. This wine was known in the Occident under the names of "Gazetum" and "Gazetinum" 7 . The wine was considered a luxury at the court of Guntram, king of Burgundia (Gregor. Turon. 7, 29). Pap. Anast. 25, $2 \mathrm{ff}$. contains a reference to the vineyards of Joppa. It reads: "When thou enterest Joppa thou findest a garden green as the spring. Thou enterest for the purpose of getting food, and thou findest there the

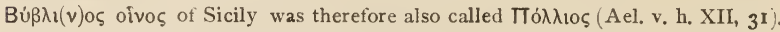
Hippys (in Athen. I, $3 \mathrm{r}$ b) states that an Argeian $\Pi$ '́ $\lambda \lambda_{1} \varsigma$, king of Syracuse. had brought the $\alpha \mu \pi \epsilon \lambda o \varsigma \beta \imath \beta \lambda i \alpha$ to Syracuse, but from Italy.

I) The famous vine-plant of Byblos was moreover cultivated in Thrace. Armenides (in Athen. I, $3 \mathbf{I}$ a) knew of a Thracian Bi $\beta \lambda i \alpha$, also called Antisare and Oisyme. Achilles Tatios (II. 2) names this wine besides the maroneic, which is a Thracian wine.

2) See also Imhoof Blumer, op. I, p. 62. Raisins of excellent quality were exported from Berytus (Plin. XVI, I8).

3) See Breast. Egypt, II, p. 46I. 4) Tot. Orb. Descr., c. 29.

5) Marc. Diac, c. V. 6) Corp. de laud. Just. min., III, $88 \mathrm{ff}$.

7) Stark, p, 562. 
ovely maiden who takes care of the wines". Idrisî refers to the viticulture of this city in conjunction with that of Ascalon and Arsûf ${ }^{1}$. In Edfu the wine of the Fenkhu is called an import article of the foreign country ${ }^{2}$.

Wherever the climate permitted it, vineyards were also in the ancient times planted in Arabia. According to Diod. I, 15 Osiris had even discovered the vine at Nysa in Arabia ${ }^{3}$. The Periplus advised the sailors to load little wine for Arabia as a place of destination, because that country produces much of it (Peripl. erythr.). Into Muza in South Arabia were imported "wine and grain, however not much, for the country itself produces a fair quantity of wheat, and a larger one of wine". The fertile valleys of al-Yaman produced at least sufficient wine for home-consumption. The poet al-A'sha of Bakr ${ }^{4}$ sings of the pleasures of the vintage at a place called Athàit. He was in possession of his own winepress. Regarding 'Anàfit [عنافت] in al-Yaman Idrisî states that, in his time, it was surrounted by vineyards. According to Bukhàrîi ${ }^{5}$ the inhabitants of al-Yaman also used to drink honey-wine (bit ${ }^{c}$ ). Sprenger, citing Hamdanî's Iklîl about the Wàdi Dahr in al-Yaman (p. $181 \mathrm{ff}$.) says: "It is situated two hours or less (west) of Șan'à and a brook waters both sides of the wàdi, which produces about twenty different kinds of grapes and all other kinds of fruit of excellent quality". Mordtmann-Müller, Sabäisehe Denkmäler, No. 11 contains an inscription which testifies to the culture of vine amongst the Bata', who dwelled near the Wàdi Dahr. Müller D. H., ibid. p. 46 states that according to Hamdànî the Wâdi

I) Jaubert, Giogr. d'Édrisi, Vol. I, p. $34 \mathrm{~S}$.

2) $801 / \int \begin{aligned} & 0 \\ & 0\end{aligned}$ Giogr. p. 650 it is said of an Egyptian coast city, $4 \square \delta_{m m}$ i. e., (to Buto of $\hat{A} \mathrm{~m}$, who resides in Egypt) the Fenkhu sail southward with their wine".

3) See also Diod. III, 64. 66; IV, 2; cf. Virg., Aen. 6, 805 und Ovid, met. 4, 13. According to Hesychius Nysa and the Nysaean mountain, amongst other countries mentioned, is also placed in Arabia.
4) A contemporary of the prophet.
5) Bukbârî, III, 78 .

Lutz, liticulture and Brewing. 
Dahr produces a certain kind of grape, called فُ طُوع regarding

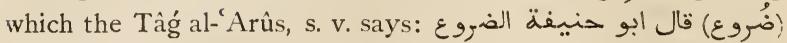

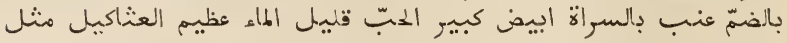

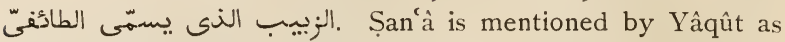
having vine-culture. Shibâm, a mount, which is situated eight parasangs west of Șan' $\hat{a}$, according to Imr. 59, 10 possessed vineyards, the fruit of which was used to make wine. G'enwân (جنوان), which is $72 \mathrm{~m}$. distant from Șan'â and $48 \mathrm{~m}$. from Sa'da, abounded in vines which produced grapes of an extraordinary size. The dried grapes were of an excellent taste and expensive. The raisins of $G^{\prime}$ enwàn were exported near and far ${ }^{1}$. According to Wellsted I, p. $103 \mathrm{ff}$, the inhabitants of G'abal akhdar in 'Oman are engaged in viticulture and make wine. Idrisî̀ states that 'Oman is growing wine. Opposite Masqat (مستط) in 'Oman, on the island of Kaish (كينّ), in the middle of the Persian gulf vine was cultivated ${ }^{3}$. The mountain valleys of 'Oman were the regions originally producing the muscatel-grape. The Periplus even states that wine was exported from Arabia to Barygaza in India. Of the latter place he says: "Wine is imported in the trading place, predominantly Italian, Laodicean and Arabian". Necca produced but a small quantity of grapes4. The vineyards of Petra ${ }^{5}$ are mentioned by Pliny $(X I V, 9,7)$. The island of Tylos in the Arabic gulf contained remarkable vines ${ }^{6}$. The surroundings of at -T ầ if and of al-Cathif were renowned for the excellence of their grapes ${ }^{7}$. Mohammed caused the vine-

I) Jaubert, o. c., Vol. I, p. I44.

2) Jaubert, o. c., Vol. I, p. I5I.

3) Jaubert, o. c., Vol. I, p. I53.

4) Jaubert, o. c., Vol. I, p. I39.

5) Doubt, however, exists, if Pliny had in mind Petra in Arabia. Fee suggested Petra in the Balearic Islands. See Dalman, G., Petra und seine Felsheiligtümer, p. 1: "Feigen, Granatäpfel, Aprikosen und Weinstöcke sind die Fruchtbäume, welche hier gedeihen". In a papal bull of Honorius III., dated Aug. 6, 1218 and which was repeated Jan. 20, 1226, giving an enumeration of the landed property of the monastery of Mount Sinai, are mentioned also the vineyards of wädì mussa near Petra. See ZDPV., Vol. X, p. 238; Röhricht, Studien zur mittelalterl. Geographie und Topographie Syriens.

6) Pliny XII, 23, I; Theophr., Hist.pl. IV, 7. 8.

7) See Abulfeda, Annal. mosl., p. 49. I26. The Omayyade caliph Yazid I. procured his wine from aț-T̂A if (v. Kremer, Culturgeschichte des Orients, I, p. I4I). 
yards of at-Tâ'if to be destroyed when he beleaguered that city ${ }^{1}$. Qazwinî II, 64 praises the grapes and the raisins of at Ṭa if. Aț-Ṭầif furnished Mecca with grapes (Idrisî, Vol. I, p. 139). A troop of the Sulaim goes to aț-T â if in order to buy provisions and wine (Dîwân of the Hudh. No. 216). In Medina, which abounded in dates, generally date-wine seems to have been drunk ${ }^{2}$. Several large kegs filled with strong drink were broken to pieces and wine-skins were emptied on the ground at the time when one of the castles of Chaibar was taken by the forces of Muhammed (Waqî̀î, $151 \mathrm{a}, 151 \mathrm{~b})^{3}$. The sixteenth Surra of the Koran (v. 69) testifies to the viticulture of the Arabs, and it shows also that they prepared palmwines ${ }^{4}$. This was before Mohammed placed the prohibition of intoxicating liquors upon his followers. On festive occasions the Arabs of pre-Mohammedan times were accustomed to use wine to excess ${ }^{5}$. A significant case of inebriation is narrated, for instance, in Abulfedae Historia Anteislamica ${ }^{6}$. For a mention of the grapes of ad-Pamr see Lebîd, XLI, 48. Sadûm Ràh (حl) سشوק), a well-inhabited fortress of considerable size, possessed many vineyards ${ }^{`}$. Palgrave ${ }^{\S}$, describing the $G^{\prime}$ auf, makes a casual mention of viticulture in that district of Nor-

I) Ibn Hishâm, ed. Wüstenfeld, 873 , and Wellhausen, J., Muhammed in Medina. Das ist Vakidi's Kitab al.Maghazi, Berlin 1882, p. 370.

2) Bukhârî, III, Kitâb al-Ashriba.

3) Wellhausen, J., Muhammed in Medina, p. 275.

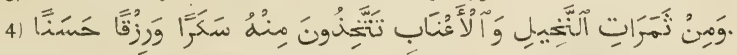

5) Geopn. II, c. 2 i; see also chapter IV.

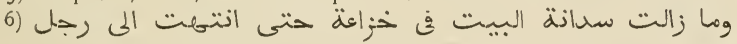

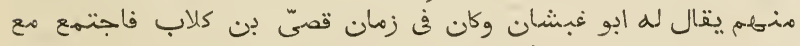

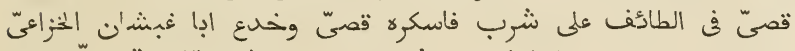
(ed. Fleischer, Lipsiae, MDCCCXXXI. p. I86, lines 6-8). I may add here the interesting passage, Yâqût, Vol. IV, p. $3^{80}$, lines 3 and 4 :

ومن وُجَّة الشَّراب (i. e. the black stone and the Zemzem-well)

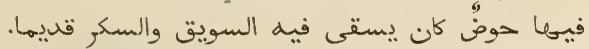

7) Jaubert, o.c., Vol, I, p. I45.

8) Palgrave, W. G., Narrative of a Year's Fourney through Central and Eastern Arabia, London, I866, Vol, I, p. 184. 
thern Arabia. He says: "Sumetimes a comfortable landed proprietor would invite us to pass an extemporary holiday morning in his garden, or rather orchard, there to eat grapes and enjoy ourselves at will, seated under clustering vine-trellises, with palm-trees above and running streams around". He further states; "The apricot and the peach, the fig-tree and the vine, abound throughout these orchards and their fruit surpasses in copiousness and flavour that supplied by the gardens of Damascus or the hills of Syria and Palestine" 1. For a casual remark on vines in Hầil see Palgrave, Narraive of a Year's Fourney through Central and Eastern Arabiu, London, 1866, Vol. I, p. 74 .

Wine grown in Arabia seems to have been generally of a red color, judging from its designation damu-'z-ziqq ${ }^{2}$, i. e., "blood of the slough". "Amr Mu'allaqat 2 speaks of the saffron color of the wine and Imr. 59, 10 compares it to gazelle-blood. Lebîd, IX, 11 mentions dark wine. From the blackish, old, tightly bound wine-skin flows wine, which foams reddish in

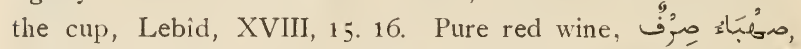
Krenkow, F., The Poetical Remains of Musallim al 'Uqaili, Leiden, 1920, I, 13. Aged wine was highly esteemed. 'Abîd V, 13,14: "And ofttimes the wine, in fragrance like broken pieces of musk - long time has it spent in the wine-jar, year after year passing by - have I quaffed in the morning before the Dawn shone forth to our mirth', in the tent of a man rich in bounty, pouring it freely to all"3. Good wine was supposed to heal headaches ${ }^{4}$. Wine was quite frequently mixed with rainwater, Lebîd, XVIII, 16; XL, 47.48; XLI, 14-16 (wine mixed with rain-water and bee-honey). Old wine mixed with rainwater, also Kais ibn al-Hațim, ed. Kowalski, XIV, 17. The PreIslamic Arabs prepared a punch from grape-juice by adding spices and hot water ${ }^{5}$. A beverage, prepared from raisins,

I) Palgrave, o.c., Vol. I, p. 59.

2) Hamâsa, ed Freytag, p. 559 .

3) Lyall, Sir Charles, The Dîwâns of 'Abîd ibn al-Abras, of Asad and 'Amir ibn at-Tufail, of 'Amir ibn Sacsa'sh, Leyden, 1913.

4) 'Alqama NIII, 9.

5) 'Amr Mu'all. 2. Wine simply mixed with hot water, Lebîd, XVII. $3^{3}$. 
was called mà scbib, "raisin-water". It had a sour taste; honey was added to sweeten it (Diwàn of the Hudhailites, 100,13). Ancient Arabia imported most of its wines from Syria.

Babylonia was no real wine country. The conditions of the soil and the climate in Southern Babylonia prohibited an extensive culture of vines. A myth, stating the reasons for the lack of extensive viticulture in that country, tells us that Dionysos was angered with the Babylonians who drank beer (sikera), and turned away from these countries ${ }^{1}$. Yet viticulture was practised in Southern Babylonia at a very early date. The earliest reference which we possess, so far, regarding the planting of vineyards in Babylonia, is that in Cylinder A, XXVIII, $10-11$ of Gudea. It reads: ne-sag-bi kur-geštin-bi$b i \cdot x "$, i. e., "The $n e-s a g$ was like a mountain (planted) with vines ....... We know also of the fact that the Babylonian vineyards had their special names as was the case in ancient Egypt $^{2}$. This bit of information we gain from Gudea, Cyl. A, XXVIII, 23-24: gišsar-gig-edin $\hat{e}$-šú sig-ga-bi kur-geštin-bi$b i-x$ ki-ni-lám-e mă-ám, i. e., "The garden 'anqullu (that is the name of the vineyard!) which was planted by the temple, was like a mountain (planted) with vines ....., which rises up on a magnificent place". This same passage is instructive from another point of view. The alluvial ground of southern Babylonia would have been detrimental to viticulture, but the early Babylonians knew this fact and planted their vineyards on artificially raised plots (Gudea: "which rises up on a magnificent place"). This fact has been overlooked by scholars so far. When we come to speak of the viticulture of the Ancient Egyptians in detail, we shall see, that the very same mode of planting vineyards was used by them. To speak of borrowing would be very hasty. The genius of both civilizations was such that each one could come upon this devise without the help of the other. In view, however, of the fact that the Babylonians at this early date at least ${ }^{3}$,

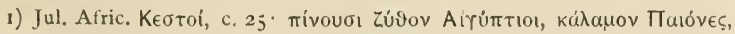

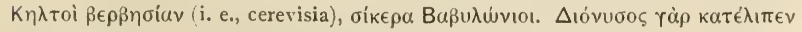

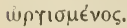

2) See following chapter.

3) This instance in Gudea is the only reference to the custom, as far as Rabylonia is concerned. 
gave special names to their vineyards, it seems that if any borrowing occured, in this instance the Babylonians were the borrowers ${ }^{1}$. In Northern Babylonia the conditions were more favorable to the vine. In some localities, we may suppose, vines even flourished luxuriantly. Nabon. 606, 10 and 869,5 show that branches bearing from fifty to a hundred grapes were no rarity. The Babylonian wine was called nectar by Chaereus in Athen. I, p. 29 f. More extensive viticulture was introduced into Babylonia during the time of the Macedonians ${ }^{2}$. During the century preceding the advent of Islam the wines of Babylonia were renowned and exported to Arabia. According to 'Abid, XXVI, 3 the wine matured in Babylonia was of a pale color:

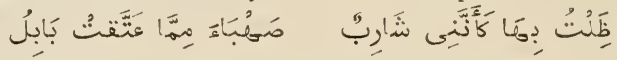

The kings of Assyria seem to have shown a great interest in the viticulture of Assyria. According to Herodotus I, c. 193 Assyria suffered from too moist a climate, which was detrimental to the raising of the vine. Herodotus, however, is emphatically wrong. Assyria was preeminently a land of corn and wine. Sanherib himself boasts that his land is such, according to

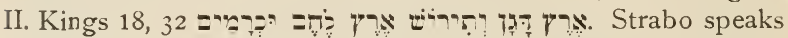
about the vines of Mesopotamia ${ }^{3}$. Asurnasirpal planted vineyards in Kalah", while Sanherib tried to acclimatize all kinds of foreign vines in Nineveh ${ }^{5}$. As a particularly good grade of wine is mentioned the "mountain-wine". It seems that the wine of the mountain of Arzabia was one of the famous wines in Assyrian times ${ }^{6}$. Hi-hi was likewise a mountain renowned for its vines. In the legend of the god of pestilence, the god is said to have cut down its grapes. The mountain called Habur (IIR 51, No. 1, 3 b) probably produced the Karan Ha-

I) The ne-sag in Gudea's cylinder A is undoubtedly the "raised plot", or, "the terrace" of the vineyard.

2) Strabo, $\mathrm{XV}, 3$.

3) Strabo, geogr. XV. Vines on the bank of the Araxes (Xenoph. Anab. I, 4, I9); wine of Caenae (ibid. II, 4, 2S). For wines of Babylonia in pre-islamic times, see Lebîd, I, $7 ; \mathrm{XVII}, 37$ and XL, 47.

4) I R 27 , No. 2,8 . 5) CT XXVI, 8, I6 ff.

6) For the mountain-vines which grew on the beights see CT XXVI, S, 2 I and Thureau-Dangin, Huiticme campagne de Sargon, line 239: "[kimai]șu gapni tar-bit šadi-i eli ubânâtšadû Ar-za-bi-a a-șu-ni". 
$b u-r u$ (II R H, 13 g). The most famous wines, however, came from the Hamrin-mountain, the holy wineland of the goddess Siris ${ }^{1}$. In the mountain of Hamrin was situated a city called Ninua $^{2}$ which was noted for its wines. The district about Bakuba north-east of Bağdâd produced plenty of wine. The village Sûnâyâ, i. e., the al-'Atîqa or Mahalla al-'Atîqa of Bag̉dàd, was renowned for its black grapes, which ripened sooner at

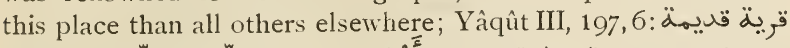

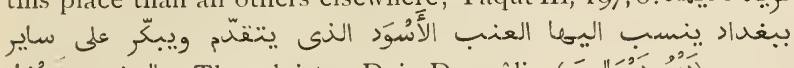

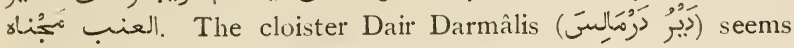
to have contained a hânût, or wineshop, judging from the words of Yàq. II, 660: "It is large and frequently visited by people on account of the revelries, the entertainments, and

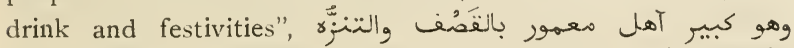
. Regarding the Dair az-Zandaward in Bağdâd Yâq. II, 665, 17 states that "it has the most excellent grapes

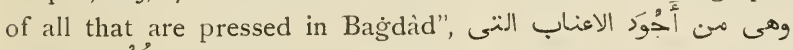
تُعْرَ ببغناد. Abû Nowâs sings (ibid.): "Bring me wine of the grapes of Zandaward the forenoon; I shall sip it in the shade of (grape)-clusters",

ماءَ العناقيد في ظلى العناقيد

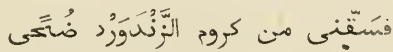

During the rule of the Sàsànides the Nestorian and Jacobite Christians possessed many cloisters in the 'Iràq whose inmates were extensively engaged in viticulture. These cloisters were the meeting-places of poets and cavaliers during the time of the Omayyades and the first 'Abbâside caliphs. Here they' were more or less safe to enjoy the excellent wines that were stored in the cellars of the cloisters. Even nunneries possessed their wineshops. Thus we read in Yàq. II, 679 regarding the Dair al-adârā (the cloister of the virgins), which was also called Dair al-'Alt from its location near 'Alț: "Halidî says: I have seen it; virgins live in it; there are also wineshops in it وقال الحالدى وشاهنتُه وبه نسوة عنارى وحانات خمر became empty of pleasure-seekers (Yàq. II, 681, 3). According to Muqaddasî grapes abounded in the neighborhood of the

I) See Hommel, Grundriss, r. $28 \mathrm{c}$.

2) C'r X, pl. $49(\mathbf{I} 4434)$, line ro. 
city of 'Ukbarà. A famous wine was grown in the village of

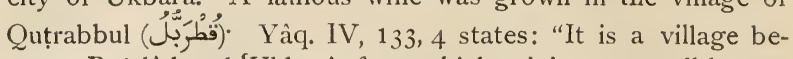
tween Bağdâd and 'Ukbarâ, from which originates a well-known wine. It is a constant pleasure-resort for people who have leisure, and a shop for wine-merchants; the poets frequently

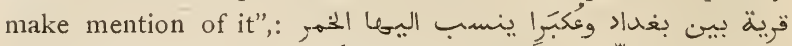

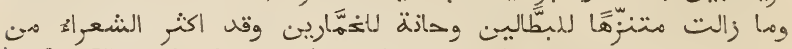
lo,s). Hauqal 167 mentions the extensive vineyards about the city of Sàmarrâ. Accordings to Johns, Assyrr. Deeds and Documents, 362,5 one single garden in Singara bore 2400 vinestalks. Some vineyards about Harrân numbered even 15000 and 29000 vinestalks (Johns, An Assyr. Doomsday Book, p. 29, Col. I, lines 21 and 35). Idrisî states that vineyards were planted along the river Hawâli (حولى) which comes from Diyàr Rebîa (ديار (بي (د). These vineyards were probably tended to by the Arabs, who lived in settled habitations on the banks of this river ${ }^{1}$. Regarding Susa, the ancient capital of Elam, the classical writers assert that there were no vines at that place before the conquest of Alexander. Only special means assured the growth of the vine. Instead of loosening the ground, the better to admit the heat, they simply drilled a hole with a rod which was fitted with an iron on one end. Into these holes they placed the shoots ${ }^{2}$.

Hommel ${ }^{3}$ conjectures that the Semites did not know the vine at all in the oldest time. This he supposes from such words as "vine", "wine", and "vineyard", which according to him are either non-Semitic words, or else imply still another, more general meaning. Thus karànu, Greek kápotvov, talm.

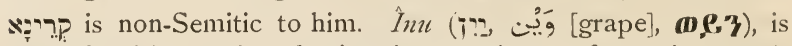
West-Semitic, and a foreign importation as far as it regards Babylonia. He further notices that karmu "vineyard", gupnu, "vine", and 'inabu, "grape", have in Assyro-Babylonian still the general meanings "acreland", "stem, pluck" (Assurnasirpal 2, 43 and 71) and "fruit" (inbu).

In Strassm. 896, 16 we possess a reference to fig-wine, inu $y_{a}$ titti. Inu $=$ wine is late in Babylonian and Hommel is right

I) Jaubert, o. c.. Vol. II, p. I 49 .

2) Strabo, geogr. XV. 3) Aufiätze und Abhandlungen, p. 93. 
in saying that $i m u$ as well as tittu (- tintu) are West-Semitic borrowings. Meissner, Assyr. Studien, VI mentions three brands of wine:

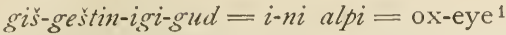

$$
\begin{aligned}
& \text { giš-geštin-sur-ra }=s a-a h \text {-tu }=\text { pressed wine } \\
& \text { giš-geštin-ha-babbar-a }=m u-z i-q u=\text { mixed wine }{ }^{2} \text {. }
\end{aligned}
$$

The date-paln grew in abundance in Babylonia. This is shown by its Sumerian name $=k a-\operatorname{lum}(-m a)$, which signifies "fruit $(k a)$ (which) grows in abundance, or, which grows luxuriantly (lum)" ${ }^{3}$. Thus date-wine supplied a cheaper drink for the poorer classes of Babylonia. According to Xenophon (Anab. II, 5, 14) it was a pleasant drink, but caused headache. Pliny $(h . n .23,51)$ states that fresh dates cause intoxication and headache. Kurunnu was the name applied to datewine, to which some sesame-oil had been added. Sometimes also cassia-leaves were used to flavor and improve the quality of the date-wine. Meissner, Babylonien und Assyrien, Heidelberg, 1920 , p. 240 observes that during the Neo-Babylonian time 1 kur (=121 l) of dates yielded one ton of date-wine. Tiâbâtu was a beverage prepared from water and a small addition of fermented fruit-juices or wine. It is frequently mentioned in medical texts. The national drink of the Babylonians, however, was always beer ${ }^{4}$. Harper $43\left(\right.$ K. 122) ${ }^{5}$ is important for our investigation, since it supplies us with a number of names of towns and districts in which the vine iwas cultivated. Obv. lines $18 \mathrm{ff}$. read: amêlu rab-kar-man m.Daian-Adad (19) âlu I-sa-na mâtu Hal-zi-ad-bar (20) âlu Bir-tum âlu Ar-zu-ḩi-na (21) âlu Arba-ilu âlu Gu-za-na (22) âlu Ša-riš alu Tam-nu-na

I) Ini alpi in Meissner, Assyr. Studien, VI, as well as înu ša šikari in Delitzscb, $I I W, 49$, are naturally different words from inu, wine. A comparison between V R 52, $64-65$ a with II $\mathrm{R} 25,38 \mathrm{a}, \mathrm{b}$ shows that a word ime $=$ mutin = karânu existed. See also Syl. S (b), line 168 (Delitzscb, AL, 3. ed., 57) $\hat{\imath}, \boldsymbol{n}=$ mamzitu $=$ pressed wine. Namzitu is probably in some instances the same as the sahtu above. See ZDMG, 48, 705. Namzitu = "must" in Str., $N b d .278$.

2) Also written munziqu and munzuqu. "Pressed" wine? More probably

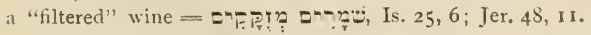

3) Delitzsch, Sum. Gl. s. v.

4) See chapter III. 5) See also $B A$ IV, p. $5^{1} 3^{\mathrm{ff}}$. 
(23) âlu Ri-mu-su, i. e., "the overseers of the vineyards Daian-Adad of Isana, in the country of Halziadbar, of Birtum, of Arzuhina, of Arba'ilu, of Guzana, of Sharish, of Tamnuna, of Rimusu". The city Isan, mentioned first, is Tell Isàn, Isân Koi, between Aleppo and Biregrik, in the plain between Sadjur and Kerzûn, $45^{\prime}$ north of Zembûr ${ }^{1}$. The city is here stated to be situated in the country (or district) of Halziadbar. Birtu was situated west of the Euphrates, and was a Hittite city ${ }^{2}$. Since the name Birtu occurs frequently, it remains doubtful, however, whether this city is meant ${ }^{3}$. The texts mention the following names of cities compounded with Birtu: Birtu-ša-Kar-ilu-bèlmâtâti, Birtu-ša-Labbanât ${ }^{4}$, Birtu-ša-Kinia ${ }^{5}$ and Birtu-ša-Sarragiti. It is more likely that one of the two latter cities is intended here, both of which seem to have been situated in the district of the Gurumu on the lower Zab ${ }^{6}$. Arzuhina (written also Ur-zu-hi-na in Harper, Assyr. and Babyl. Letters, IV) and Arba'ilu are well known cities. The former, according to II R 65, $15.16 \mathrm{~b}^{7}$ was situated on the lower Zab river and opposite the city of Zaban. Arba'ilu ('A $\rho \beta \eta \lambda \alpha$, modern Erbill) lay between the upper and the lower Zab. Guzana is a city which is mentioned in the Old Testament (7Tig, II. Kings 17,$6 ; 18,11 ; 19,12$; Is. 37,12 ; I. Chr. 5, 26) s. It was situated on the river Hâbûr. The last city mentioned in the Harper text, Rimusu lay on a canal of the river Husur ${ }^{9}$. All of these cities had vineyards over which a rab-karmani, "an overseer of the vineyards" was placed. Tablet K. $3+^{610}$ mentions an overseer of the vineyards

I) See PSBA, June I882, p. II 7 and $B A$ II, p. 49.

2 Thus according to Salm. Obel., 33-35.

3) This doubt is raised in $B A$ IV, p. $5^{\mathrm{I}} 3$.

4) Tigl. Pil., Claytablet inscr. $8 . \quad 5)$ Ibid.

6) See Schiffer, Die Aramäer, p. 123.

7) Ina eli âlu Za-ban šu-ba-li-e ina tar-și âlu Ar-zu-hî-na.

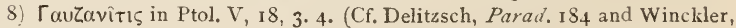
KAT, 269).

9) B.A IV, p. 516 cites San. Bav., 8- I I "ultu libbi ..... âlu Ri-mu-sa ......... I 8 nârâte ušab̧râ ana libbinâru Husur ušêsir". It is the sixth of I 8 villages which were connected by a canal with the river Choser, which sheds its waters into the Tigris south of Kuyungik. See also, Delitzsch, $P a$ $\mathrm{rad} . \mathrm{I} 87 \mathrm{ff}$.

10) III R 48 , No. $4(=K B$ IV, P. II 4, No. 2 
of the city of Maganuba. Since the document is dated in the eponymate of Ilu-ittia, the governor of Damascus ${ }^{1}$, it is most likely that the city of Maganuba lay within the district of Damascus. This would give us an additional Assyrian testimony of the viticulture of the district of Damascus ${ }^{2}$. In mât Așalli Adad-'i-me brings to Ašutrnàșirpal in the year of $877 \mathrm{~B}$. C. among other tribute also wine. Bit-Adini was an excellent wine-growing country. Ahùni of Bît-Adini offers wine as tribute to Salmanassar II. in 859 B. C. Wine is also mentioned among the tribute of Hapini of Tilabnê, Ga' uni of Sa[rugi], i. e., שִ (Gen. $\mathrm{X}, 20-23$ ) and Giri-Dadi of . . . . . . . . Sarugi is the district of Serûg, between Belîh and the Euphrates, south-east of 'Arab-Dagh ${ }^{3}$. Mutallu of Gurgum, whose capital was Marqasi, modern Mar'ash, also furnishes wine to Salmanassar II, according to the list of tribute. So does Arame apil Gusi, king of the Patinaean cities of Taiâ, Hazàz (Azàz), Nulia and Butàmu. Nebukadnezzar praises the wines of màt Izallam, màt Tu'immu, màt Șimmini, màt Hilbunim, màt Aranabanim, màt Sûtıam (extenting from above the mouth of the river Belîh towards the mouth of the Hàbûr; probably ज्ञ Job II, 11), màt Bìt-Kubatim and màt Bitàtim (I R 65 I, 22-25, Grot. Cyl.). The wine of these countries he offered up, continually, like the water of the river on the altar of Marduk and of Zarpanitum. Imr. 59, 10 and 'Alqama (ed. Socin II, 41) mention the wine of 'Âna at the upper Euphrates. At alBahrain the vines were planted between the date-palms. In PreIslàmic times Babylonia exported some wine to Arabiat.

Amongst the multitude of business documents of Assyria and Babylonia, there are some which refer to the sale of wine, which we shall presently discuss. K. $423^{5}$ reads: “「. . shekel]s

I) Year 694 B. C.

2) I R 65-66 a, 2I-23; b $3 \mathrm{I}-32$ end, II $\mathrm{R}$ mentions as wine-countries Hulbum and Izallu.

3) Schiffer, Die Aramäer, p. 64 .

4) Lebîd, I, 7 ; XVII, $37 ; \mathrm{XL}, 47$.

5) See Johns, Assyr. Deeds and Documents, 125 :

(I) [... šiḳlu] meš ša mâtu Gar-ga-miš (2) ‘̌a m.....-abu-u-a (3) a-na m. Bêl-ahhêemeš ina libbibi (4) 9 imêru karâni meś ina gỉs-bar ša 9 qa (5) ina mâtu Bît-Za-ma-a-ni iddanana (6) [šum]-ma la iddinini a-ki ma-hi-ri (7) ia 
of silver of Carchemish [belonging to .......-abùa, for Bêlahhê. For it he shall give nine imer of wine to the measure of nine $q a$ in Bit-Zamàni; if he does not give (the wine), he shall give according to the marketprice of Nineveh. In the presence of Ribà, of Batiti, the shelaphi-officer, of ShêpàAshur, of Ubuku, of Mannu-kî-Nînua, of Nabû-bêl-ilàni. The third day of Shebat( $)$ in the eponymate of Sin-ahhê-eriba" 1. The money paid for the delivery of the nine imers oi wine is that of the standard of Carchemish, the capital of the former Southern Hittite kingdom, after the break-up of the unified Hittite empire of Shubbiluliuma. Since 876 B. C. that part of the former Hittite kingdom was, however, in the hands of the Assyrians. But it still uses in 687 B. C. its own monetary standard. The wine shall be given in Bit-Zamàni. The country of Bit-Zamàni was situated north of the Kashiari mountain, modern Ṭur-'Abdin, mons Masius, tò Máoı ö öpo of the classical writers, along the river Tigris. Its capital was Amedi (or Amedu), i. e., Amida of the Classics, modern DiyârBekr, turk. Kara-Amid ${ }^{2}$. K. 361 refers to the sale of wine to be imported to Nineveh. "2 imer 50 qa of wine, belonging to Mannu-kî-Nînua (are) at the disposition of Uttàma. In the month of Iyar he shall give the wine [in] Nineveh. [If he does not give (the wine), he shall give silver according to the marketprice of Nineveh. The 25 th day of Tebet, of the eponymate of Mannu-kî-Adad" ${ }^{3}$. A similar text $^{4}$ speaks of the delivery of wine according to the measure

âlu Nînua iddanimes̉ (S) mahar m.Ri-ba-a-a (9) mahar m.Ba-ti-i-ti (Io) amêlu šela-pa-a-a mahar m-škêpâ-Ašuršur (II) mahar m. Ć-bu-ku (I2) mahar m.Man-nuki-âlu Nî̀nua (I3) mahar m. ilu Nabû-bêl-ilâni meš (I 4 ) arhuS̉abâțu( (?) ûmu 3 -kam (15) lim-mu] m.ilu Sin-ahhê meš-erîba".

I) I. e., $68_{7}$ B. C.

2) Cf. Schrader, E., Die Keilinschriften und Geschichtsforschung, p. 146 Delitzsch, Fr., Wo lag das Paradies, p. 276; Streck, ZA, 1S93, XIII, p. 73 and Schiffer, Die Aramäer, pp. 76-So.

3) "2 imêru 50 qa iṣukarânimes̀ (2) ša m.Man-nu-ki-Nînuaki (3) ina pân m.Ut-ta-a-ma (4) [ina] arh̆u Aiaru iṣu karânu meš (5) ina âlu Ni-nu-a iddan an (6) šumma] la i-di-ni (7) [ki ma-h]i-ri ša Nînuaki (8) [kaspu] iddanan (9) [arbự̣̂ebêtu ûmu] 25-kam (ro) [lim-me m.Man-n 'u-ki-ilu_Adad (II)" follow witnesses. The year is that of $68_{3} \mathrm{~B}$. C.

4 Johns, Assyr. Deeds and Documents, I24, 81-2-4-15I. 
of the king ${ }^{1}$. In case the wine is not delivered, the wineseller must give another wine corresponding with the marketprice of Nineveh. All these documents show that the price of wine was subject to a special tariff in Assyria. The wines imported into Assyria, it seems, were subject to an extra custom-house tax. This additional tax naturally made the imported wines much more expensive than the home-grown wines. In case the winesellers from districts outside of Assyria proper did not fill their orders, they were compelled, according to these documents $^{2}$, to give an equal quantity of wine ordered, subject only to the tariff of Nineveh. In this case, therefore, the revenue on the wine would have to be borne by the wineseller, and not by the buyer.

I 5 imer of wine according to the $q a(-$ measure $)$ of the king.

2 ki ma-h̆îri s̀a Nînuaki. 


\section{Chapter Two}

\section{The Vineyard, the Vintage, and the Making of Wine in the Ancient Orient}

The numerous wall-paintings in Egyptian tombs enable us to reproduce a fairly detailed account of the Egyptian

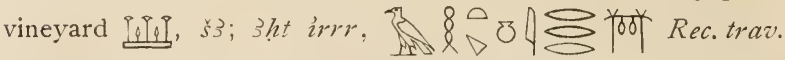
6, 7, Coptic $1 \lambda 2 \lambda \lambda \lambda_{0} \lambda_{1} ; 33$ d.t, 4 \}

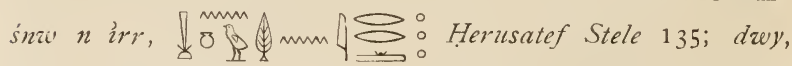

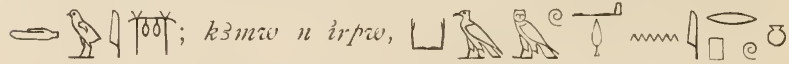

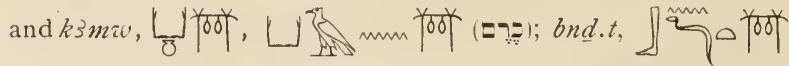

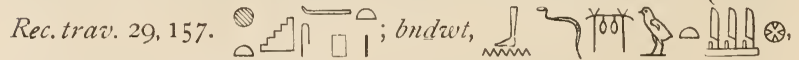
$\int_{n m}^{2}$, bnd.t see Mariette, Mastabas, pp. 181 and $186^{1}$. The vineyard was generally planted on an artificially raised plot, whenever the district lacked hills or mountains. It was always

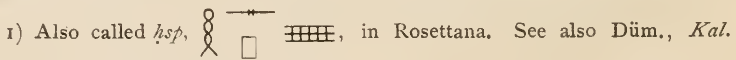

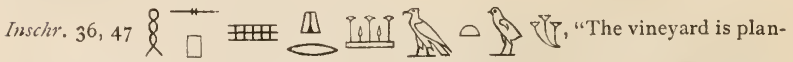

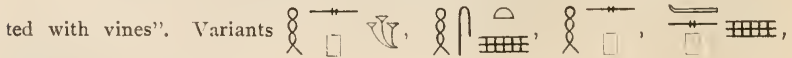
开开 etc. 
surrounded by a stone-, or clay-wall, judging from the wallpaintings (see Illustration No. 3). But since these paintings present to us only the vineyards of distinguished and rich persons, there is no doubt that poorer vineyard owners contended themselves with the less costly hedges. There is a strong doubt, however, whether during the early periods of the Egyptian history vineyards were in the possession of Egyptian commoners.

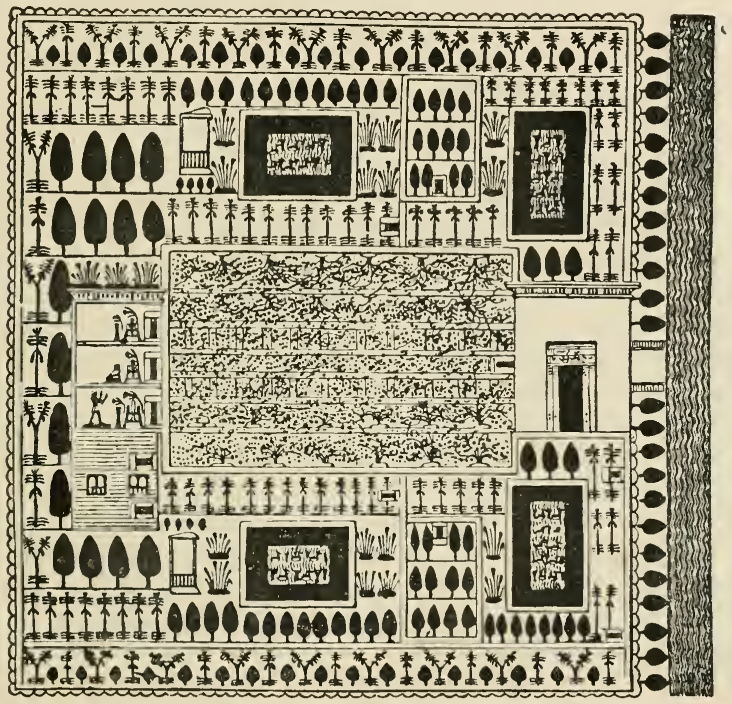

No. 3. A large garden with vineyard in centre (after Wilkinson, The Ancient Egyptians).

The political and economic conditions of the time of the Thinites and the Old- and Middle Kingdoms, probably did not permit it. Vineyards at that early age were an expensive luxury which the king and some great officials, like Methen, could indulge in, rather than a profitable investment.

The sealing-inscriptions on the clay stoppers, which closed the large wine jars of the pre-dynastic and Thinitic graves bear 
the first testimony to vineyards in Egypt. According to these inscriptions the earliest vineyards, which were situated near the so-called "White Wall", near Memphis ${ }^{1}$, were of an oval shape, and enclosed by a spiked wall. Every king of the early dynasties possessed a special vineyard, which furnished the funerary wine for the royal family and the royal servants ${ }^{2}$. It is of course only an accident that we know only of these vineyards, dedicated to ceremonial purposes. Besides these "sacred vineyards" the early kings undoubtedly also possessed their private gardens, whose produce adorned the royal table. From these sealing inscriptions we learn that each vineyard had its special name. Whether this was true of the vineyards in private possession is not known. All the vineyards known to have had special names are vineyards dedicated to ceremonial purposes, or, as was seemingly the case with the vineyard called $k a-n-k e m e t$, i. e. "the genius of Egypt", to ceremonial purposes and to the royal usufruct. The vineyard, called "anqullu", which we have seen Gudea planted, was also intended solely for religious purposes. These vineyard names are thus no forerunners of the present custom of American farmers to call their farms by names such as "Fair-View Farm", "Glen-Side Farm", "Sunny Brook Farm", etc. The names of the Egyptian vineyards always refer to some religious idea. In the oldest names is contained, in each instance, an expression of a certain divine quality of the god Horus. King Zoser's vineyard was named "Praised be Horus, who is in the front of heaven" 3 . Khasekhemui's vinegarden bore the name "Praised be the souls of Horus" 4 . These expressions,

I) The vineyards of Nebesheh, $\mathrm{Nh} 3 \mathrm{mw}$ and Sajn, however, seem to go back to the same remote age, according to the Pyr. texts; see above p. II.

2) Quite a number of wine jars were found in the tomb of king IInt IIT. Most of them had been broken, but a few still preserved their conical stoppers. See Amelineau, M., Le Tömbeau d'Osiris, Paris, 1899, chapt. 5, p. 9 I ff. and Petrie, Royal Tombs.

3) $*$ Snd th of Heaven". Over the vineyard estate founded by Zoser was placed a local governor; see Sethe, Urkunden 1, 11-15.

4) $D w^{3}-63 z v-H r$. 
however, have undergone already a stage of development, for the name of the vineyard of the Horus Dja, of the predynastic time, is still simply "Beverage of Horus", or else, "Enclosure of the beverage of Horus". On one of Dja's cylinders the name is also called "Beverages of the Double $(k 3)$ of the enclosure of the beverages of Horus" ${ }^{1}$. Commen-

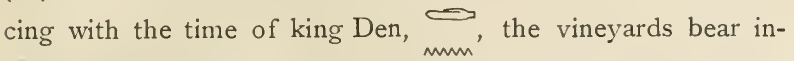
variably the name "Enclosure of the beverages of the body of Horus".

Viticulture is a sure sign of a higher degree of civilization, since it required a greater amount of labor than the cultivation of grain and demanded years of patient waiting and tending, until the young shoots had grown up to bear fruit. Irrigation was one of the tasks to which the Egyptian vinedresser had to give much of his time. The gardener "passes the morning watering vegetables, the evening vines" (Pap. Sall. II; Pap. Anast. VII). The Egyptian vineyard is often pictured as having a water-basin. The vines were trained on e:paliers or trellis work, which was supported by transverse rafters, resting on beautifully carved and painted columns. Rows of columns formed pleasant arcades. The avenues were generally wide enough to permit an easy communication from one end of the vineyard to the other, and yet not too wide; the rays of the sun being kept away from the ground in order that it might retain its moisture. The vine-arbors of a more simple make-up consisted simply of pliable branches, whose ends were placed in the ground, thus forming a large arch. A third way was that of erecting two wooden pillars, whose upper ends were forked, over which a wooden pole was layed. Vinedressers who were less careful, simply allowed the vinestalks to shoot up without any props, as is seen in an illustration from Beni-Hasan, or else they let them grow up in hedges. Such vines, as were allowed to grow up as bushes, were kept low and required no support. The different modes

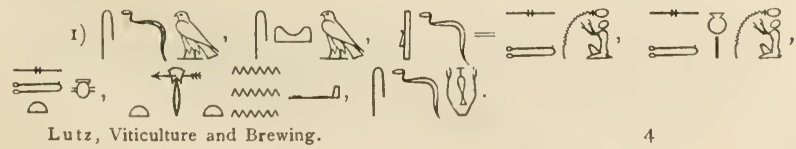


of propping the vine are exemplified in the hieroglyphs for

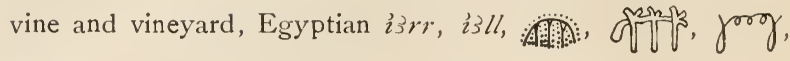
frof 1 . The Egyptians do not seem to have attached the vine to trees. It is, however, possible that they trained them sometimes on papyrus, whenever this was practicable. We possess no Egyptian references to this mode of training the vine, but since the Mishna refers to that practise, we may infer that it was also an Egyptian custom ${ }^{2}$. The various modes of arranging the vineyards and the different ways of training the vines naturally depended much upon the tastes of the owners and on the nature of the locality and the ground. In the tomb-painting of Paheri at al-Kab the vinestalks round about the roots are banked with earth. The earth-heaps are cup-shaped in order to hold the water for a greater length of time. The hieroglyph of the vine in Ptah-hotep, Vol. I, Pl. X, No. $166^{3}$ which is painted shows the props in red, the vine-foliage green with dull maroon longitudinal stripes indicating the stems, and the grape-clusters blue. More often the grapes are painted red or reddish brown. The leaves are seldom drawn and show sometimes the same color as the grapes. One picture from Thebes shows an espalier on which lotus-plants are climbing up. The ancient Egyptians already had a knowledge that certain grapes do not promise any fruit. These grapes were cut off with a special knife which was of a sickle-shaped form. The grape (-cluster), $4 \lesssim 4,4 \sum_{000}^{\infty}$, is represented in different forms on the monuments. In the temple of Der-el-Bahri we meet with this form: 13 ; L.D., III, 244 ( the form: Purely realistically drawn grapes are mostly seen in the paintings of the $17^{\text {th }}, 18$ th and the following dynasties. The color is then of a beautiful dark blue,

I) See L. D.. II, 53; and III, II.

2) Kilaim 6, 3 "whoever trains the

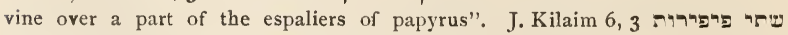

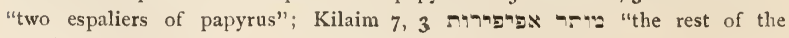
espaliers of papyrus".

3) See also No. $173=$ No. 405 . 
while the berries are indicated by black dots. Sometimes the cluster is painted in pink or a pale violet. According to the wallpaintings the Egyptians knew white, pink, greenish, red and dark blue grapes. Whenever the grapes are painted black, as for instance, in the tomb of Sennofri near Sheikhabd-al-Gurnah, blue or dark blue is naturally intended. The Egyptians, as well as all Orientals, have great difficulty in distinguishing between these two colors. In the tomb of Thut-hotep at al-Bersheh ${ }^{1}$ the grapes are of a greenish color. At the time of the ripening of the grapes great care was taken to preserve the clusters from the birds.

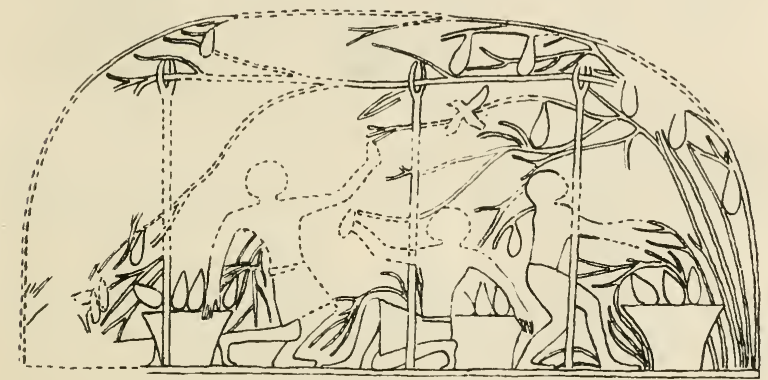

No. 4. Vintage-scene (after Petric, Deshasheh.

Men, women and children participated at the time of vin-

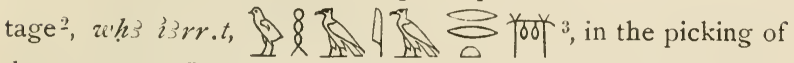
the grapes (see Illustrations Nos. 4, 5,6 and 7 ). The bunches were carefully put into deep wicker-baskets ${ }^{4}$. When these were filled, men carried the baskets either on their head, or shoulders, or slung upon a yoke to the winepress. These men are sometimes seen marching in file, and in the tomb of Ti the legend $\AA_{0}^{\mathrm{mm}}$

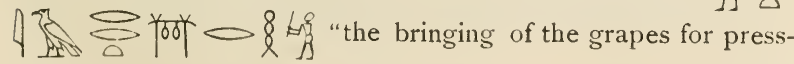

I) See Newberry, El-bersheh, I, pl. 24, 26, 3I.

2) The vintage took place in the month Epiphi, towards the end of Junc or the commencement of July.

3) T'omb of Ptah-ḥotep. 4) So according to Virg. Gcorg. II, 24 I. 
ing" is written below the picture of the carriers. Those grapes, however, which were not used for the making of wine, were placed in flat, open baskets, which were then covered

$$
\text { †ण } 19,9 \underset{\rightarrow 0}{\longrightarrow}
$$

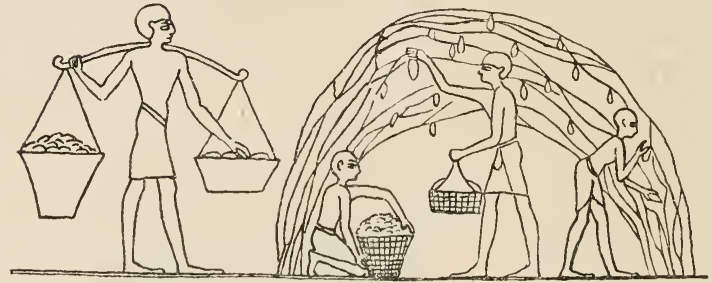

No. 5. Gathering grapes (after Wilkinson, The Ancient Egyptians).

with palm leaves, or vine foliage. Tomb No. XIV in Sauiet al-Meitin, which dates back to the sixth dynasty ${ }^{1}$ represents

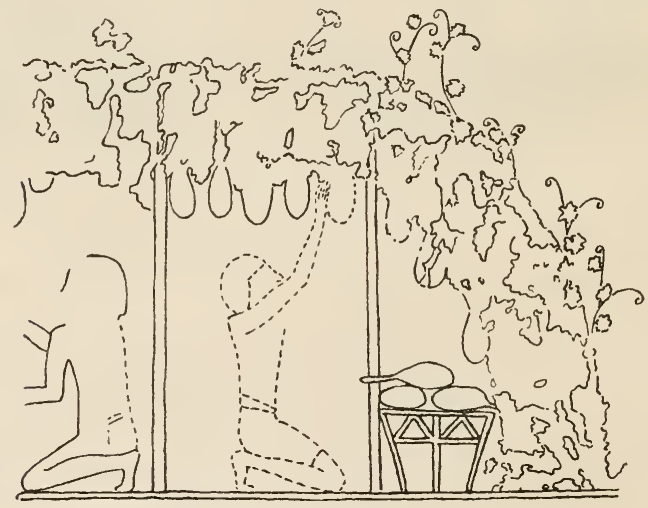

No. 6. Vintage-scene.

in one of its paintings the end of the vintage. The espaliers are seen without foliage and without grapes. The workers

I) L. D., II, 53 and III. 
are seen below with the grape-filled baskets. In the wallpainting of Beni-Hasan two long-horned goats climb up the bush and browse on the vine foliage. It seems thus that after the vintage was over the domesticated animals were allowed to enter the vineyards in order to browse upon the vines.

The grapes were put into large vats, inside of which at least four men could find sufficient room. The paintings sometimes show five or six men standing in such vats. The vat was always placed on a slight elevation, and during the New Empire was round in form. The paintings do not show very distinctly the form of the vat in the time preceding the New Empire, but it is possible to think that they were generally round in form. The layer of grapes in the vat, which was of acacia wood, was not deep. It hardly went beyond the ankles of the vine-pressers, who pressed the grapes with their feet. The large vat was sometimes covered with a roof. From the roof or the cover hung down as many ropes as men were

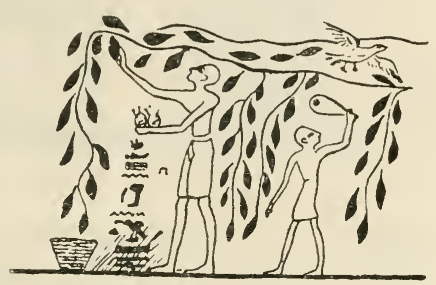

No. 7. Plucking grapes and frigthening away birds with a sling (after Wilkinson, The Ancient Egyptians). able to find standing room in the vat. In case that there was no roof or cover supplied with ropes which were held by the men in order to hold their balance. the men at both extremities of the vat held on to poles, which were placed on both sides. The men between the two secured their position by holding each other by the hips. The winepressers next made the round in the vat, while singing a rhythmic song. Two men near the winepress marked the rhythm by simply clapping their hands, or else by a special object, which was of a rectangular form ${ }^{1}$. It is possible that sometimes women were called upon to mark the rhythm, and to keep time for the dancing men inside of the

I) See L. D., Ergänzungen, pl. 2 I. 
press $^{1}$. In the tomb of Mera the work of these time, keepers is called 3 s $8 \sim$, i. e., "to clap", "to produce a sound by clapping". The grape juice flowed through a bung on the side of the press into smaller vats, in which the juice was brought to fermentation ${ }^{2}$. A second pressing was necessary in order to extract the juice which still remained in the grapes $^{3}$. We observe on the wall-paintings of Beni-Hasan ${ }^{4}$ an oblong linen slough, which is filled with wine-lees removed from the winepress (see Illustration No. 8). This slough is

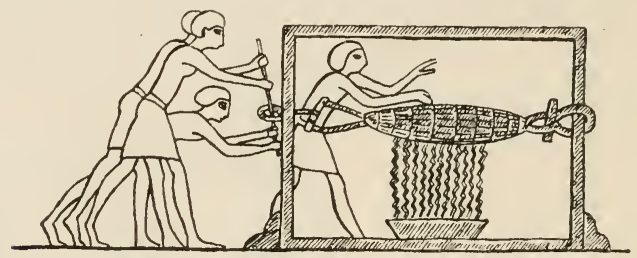

No. 8. Winepress (after Wilkinson, The Ancient Egyptians).

stretched out between a strong wooden frames. Men are turning the cloth with sticks, which are placed through the ends of the slough. The pressed wine flows into a large

I) In the tomb of $\mathrm{Ti}$, the daughter of one of the workmen is seen unwrapping herself and going up to the press. She is probably one of the musicians or timekeepers. See also L. D. II, 96.

2) The Egyptian word for "fermentation" occurs i. i. in d'Orb, r 2, 10

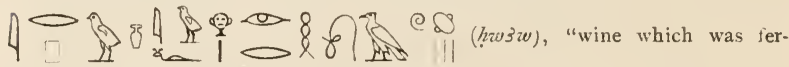

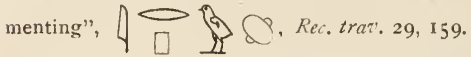

3) See Klebs, Die Tiefendimension in der Zeichnung des alten Reichs, in Aeg. Z. 1914, pp. 24-28, and Montet, Rec. d. trav. XXXV, p. $120 \mathrm{ff}$.

4) See Newberry, Beni-Hasan I, pl. 29, II, 4, I3.

5) In A. St. G. Caulfeild, The Temple of the Kings of Abydos, Egypt. Res. Account, $1902, \mathrm{pl} . \mathrm{XX}$, there is an additional crosshead attached to the end of the slough, which permits the cloth to be twisted tighter. - The winepress is called and Sethe, Urkunden der 18. Dyn., Leipzig, r906-09, p. 687. 
earthen jar, which is placed below the linen slough. To twist it must have been a very difficult task. It generally required four persons. A fifth person seen on the wall painting of the tomb of Ismaih at Gizeh, of the fifth dynasty, seems to keep both poles apart by holding the poles at the proper distance with both his hands and his feet (see Illustration No. 9). This is of course an acrobatic trick which it was impossible to perform. But these drawings are not faithful to perspective. The fifth person was in the centre, but since he could not be drawn without some part of his body being

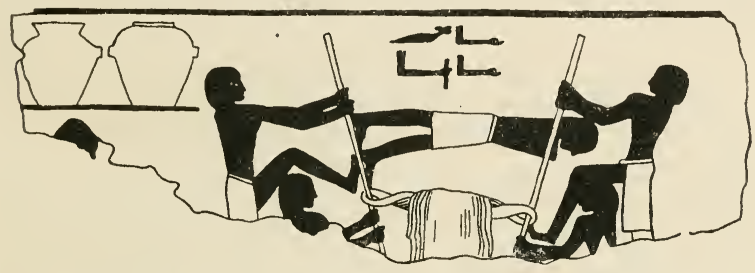

No. 9. The pressing of wine-lees (after Newberry, Percy E., El-Bersheh).

hidden by the cloth, the artist chose this impossible position for him. This person's work consisted in seeing that the wine flowed exactly into the large jar and that nothing was spilt. $\mathrm{He}$ is called sho šms, 79 g, while the other men are the šmsie, 鸟.

While the winepress of Beni-Hasan referred to above shows already a solid structure at the two ends of which the linen slough is attached ${ }^{1}$, the tombs of the Old Kingdom show us still the more rude way with men wrenching the poles in opposite directions. This process of pressing the grapes in the slough (see Illustration No. 9) is designated by the word " $f$, in the Middle Kingdom. In Beni-Hasan ${ }^{2}$ its orthography

I) So also Caulfeild, The Temple of the Kings of Abydos, Egypt. Res. Account, 1902, pl. XX.

2) Newberry, Bcni-Hasan, I, pl, 29; II, 4, I3 (PI. 29 in Newberry =-

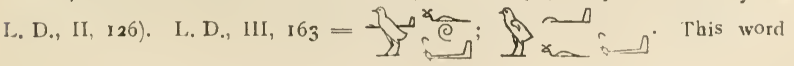


is if, 4 , which means "to press, to turn, to wring, to turn the linen slough'. Rosellini II, 66 shows two women turning a slough, filled with winelees. Rec.trav. 21, p. 6 pictures a wine-press with two sloughs instead of the customary one. In the Thebaid the footpress is only represented and thus, we may conjecture, was only used there, without the second process of pressing the winelees. The wallpainting of Ptah-hotep in BeniHasan ${ }^{1}$ representing the pressing of the lees is unique. The sticks cross each other, and the slough is attached to the lower extremity. These modifications are due to the artist's desire to show the completion of the work of pressing. The slough is completely curled up. By pushing the linen slough towards the end, the workers gained greater force. This could of course not be done as long as the sack was still filled with winelees, since it would have shifted all the pressure and the greatest amount of work and weight on the worker nearest to the slough. L. D., II, 53 shows further the heating of the grapejuice, probably in order to hasten the process of fermentation. Next, the wine was filtered. Two men stretch a large piece of cloth over a kettle while a third pours the wine into the cloth. The wine finally is poured into large variegated stone- and earthen jars (see Illustration No. 10). The short, but wide-necked jars were then closed with covers, stone plates, globular or differently shaped stoppers and sealed ${ }^{2}$. The wine which was destined for funerary purposes, however, was put into very small vases ${ }^{3}$, which were closed in the manner of perfume vases ${ }^{4}$. The Egyptians, before pouring the wine into the jars, generally smeared the bottoms with resin or bitumen. This

is also used for "braiding the hair", cf. Chab. voy. 119. The original meaning seems to have been "to wrap into a bundle".

1) Newberry, Beni-Hasan, I, pl. $3^{6}$.

2) On the east wall of the mastaba of Akhethotep at Saqqareh, men are emptying wine into large open-necked jars. The two storage jars, which are long-necked, stand near $\mathrm{b}_{4}$.

3) See Petrie, Medum, pl, I.

4) L. D., II, 96 with the legend:
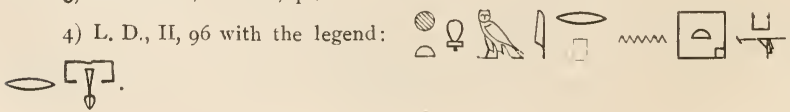
was done in order to preserve the wine. It was also thought to improve the flavor of the wine. Wine was sometimes also put into skins, a mode which probably prevailed throughout all times of Egyptian history, whenever such wine was intended to be taken on long journeys. Lepsius, Auswahl, 12, 5 refers

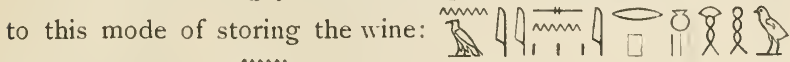

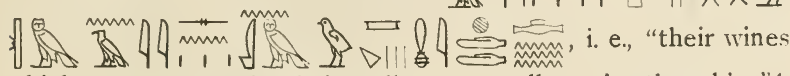
which were stored in their cellars as well as in the skins"!. When the wine had been stored away in the cellars, they

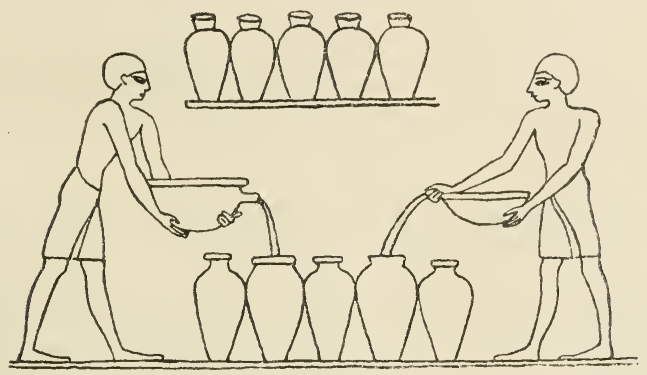

No. 10. Pouring wine into iars (after Wilkinson, The Ancient Egyptians).

were marked with wine labels. In $A e g . Z$., 1883, p. $33 \mathrm{ff}$, the first Theban ostracon of this kind was discussed. It reads:

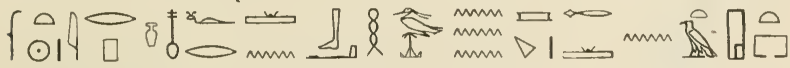
(०) ती ह)

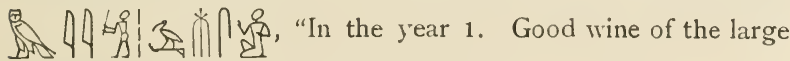
irrigated terrain of the temple of Ramses II. in Per-Amon. The chief of the wine-dressers, Tutmes". Many of such wine labels have been published since by Spiegelberg, Hieratic Ostraca

I) The wine-skin is also called 8 , a word used to denote more comlmonly the leather-bag and 
and Papyri ${ }^{1}$. In these ostraca reference is made to the vineyards ka-n-kemet and to the "large irrigated terrain in PerAmon" ${ }^{2}$, which is on the west-side of the landing-place. The same publication offers two additional names of vineyards, to which W. Max Müller first drew attention in OLZ, 1896, Vol. II, p. 367. The one is called the "vineyard (lisbt:) $N(e)-h-\ddot{i} r a-y-n a$ " (determ. water) = nahlayn "double-brook", a dual-formation of מהל, Assyr. nahlu; III R 35, No. 4 Obv. 12: na-lual màt Mu-sur ašar nâru lâ $i \hat{s} \hat{s} \hat{u}$, "the brook of the country of Mușur, where there is no river". The other vineyard was named $p-N-s-b u$ (determ. tree), = ב::, "the prop". These wine labels served two purposes. First, to show the age of the wine in the different jars, and second, to mark the quality of the wine. The quality is expressed by "good wine" (Spiegelberg, Ostraca, Nos. 140, 162, 248, 257, 259, 262, 291 and 299), "sweet wine", (Nos. 186, 224, 266), and "very good wine" (Nos. 177, 195, $197,229,255,256)$. The wine was inspected and tested by special officers called "inspector of the wine test" (Pap. Leiden, I, 348,10$)^{3}$. The paintings show us also the mode of storing away new wine in Egypt (see Illustration No. 11). The jars, which were pointed at the bottom *, rested either in the ground, or they were attached to a wooden stand or a stone ring (see Illustration No.12). They were placed in successive rows. That row which rested against the back wall of the wine cellar was the last one used and therefore contained the oldest wines. A wine cellar in Esna ${ }^{5}$ contains the legend: "This is the wine cellar.

I) Egyptian Research Account, I898, pl. XIX-XXXV.

2) Concerning the geographic situation of the vineyard I see Spiegelberg, Rec. Irar', I6, p. 64 "'Irit, the daughter of the ship-captain B3n-'nty (has become) the wife of the royal prince $S-m n t w$, who is in the vineyard of the temple of Ramses II. at Memphis".

3) 4$]$ e waltung Aegypt. unter den Phar.

4) Large, hard-baked clay winejars, which were pointed at the base, were in use by the Orientals and Greeks and Romans alike. In Hebrew these jars are called Kad, while in Syriac they bore the name dannâ, which word passed later into the Arabic language, dann, pl, dinân. Babyl. dannu.

5) See Brugsch, $W B$, Vol. VI, p. 611. A rare word probably denoting wine-cellar' occurs in Müller, W. Max, Die Liebespoesie der alten Ägypier, 
The place for the produce of the vine is in it. One is merry in it, and the heart of him, who goes forth from it, rejoices",

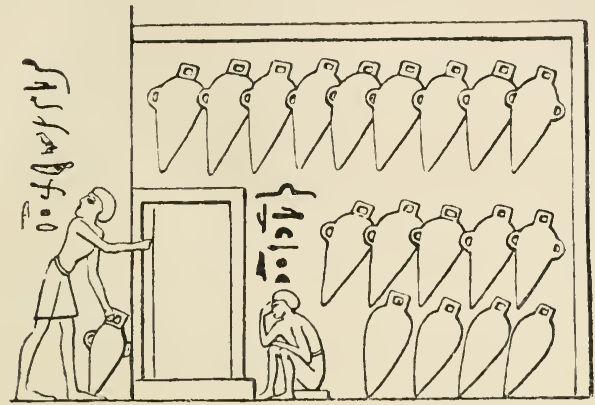

o. II. The storing of wine (after Wilkinson, The Ancient Egyptians).

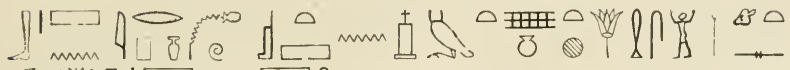

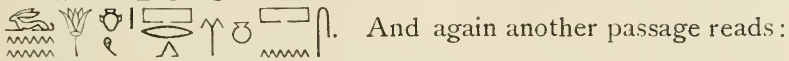
"This is the white(washed) room of the grapes, furnished with the best ingredients for the preparing of the produce of the Horus-eye. Different spices are there in their multitude and the grape is in its closed room at the going forth from the stalk",

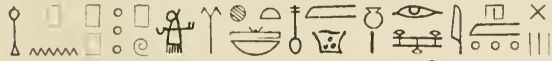

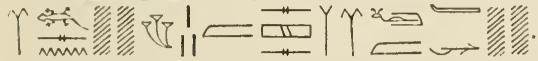

The official vineyards of Egypt were No. I2. Wine-jar supunder the special care of an officer cal- ported by a stone-ring led 'nd-mr.

Leipzig. $1899,3,12$ didi, i. e., the place where the didi-vessels are stored. For an interesting graphic variant of 'wine-cellar' see BWB, I, p. 234: $\Delta \circ \min _{\Delta}$ 
the vineyard, or of the vineyard, i. e., "the superinten dent of the vineyard" 1 . Vineyards owned by the temple-fiscu or the king were naturally exempt from taxes. In the earl Ptolemean times there existed a tax, called ḋópoto $\alpha$, whic was paid by the possessors of vineyards and gardens for th support of the temples. This tax amounted to the sixth par of the yearly produce of each vine-land. Ptolemy II., Phila delphos, however, took away the benefit of this tax from th priests and appropriated it to the use of the queen Arsino Philadelphos, who had earlier been declared a goddess, an now was regarded as having a perfectly legitimate right to $i$ The tax was presumeably only partially used for the cult c the new goddess, while the remainder went into the stat treasury. Prior to the decree of Philadelphos, the owners vine-land paid their tax in furnishing a certain stipulated quan tity of wine, or, in isolated cases, in the payment of money Philadelphos later permitted certain clásses (f. i. the military colo

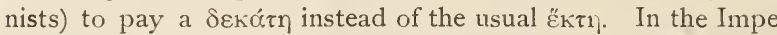
rial Roman time a tax $\dot{v} \pi \dot{\rho} \rho \dot{\alpha} \mu \pi \varepsilon \lambda \omega^{\prime} \omega \omega v$ i. e., "for vineyards' was raised, which was a land-tax for the owners of privat

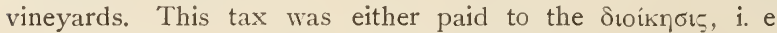
the state-resort, or to the icpó, the temple-resort. Dr. Wilcken has shown that the amount of taxes paid for vineyards varie at this time between twenty and three-hundred and fift drachmae per arura. This difference in taxation was due $t$ the different qualities of the vineyards and to their differen locations. In case of a poor inundation a lighter tax wa sometimes placed on the owner of a vineyard ${ }^{3}$. Wilcken als observed that a tax of twenty to forty drachmae per arur

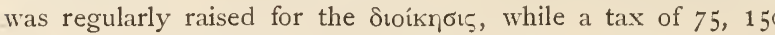
or even 350 drachmae was regularly due to the iepó. H established the fact that the land tax of the best and mo: productive vineyards of the Theban district was raised fo the temple treasury. The taxes for vineyards had to be paic

I) Pap. Anast., IV, pl, 7,3 mentions a master of the vineyard, in whos storehouses a rich quantity of wine was placed.

2) Griechische Ostraka, pp. $147 \mathrm{ff}$.

3) See Grenf. (II) LVI and compare chapt. I of Wilcken, Griech. Ost, 


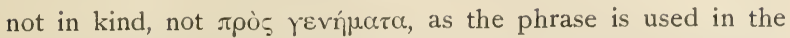

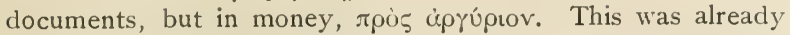
the rule in the Ptolemaic times ${ }^{1}$. For instance in the petition

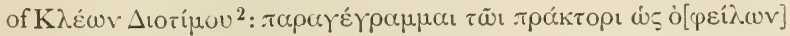

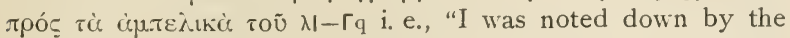
practor for being ninety drachmae in arrears for the land tax of the vineyard of the thirtieth year". Since the third century B. C. the land tax for vineyards was always paid in cash and Wilcken notes only one exception. He cites line $30 \mathrm{ff}$. of the decree of Rosette, according to which Ptolemy V., Epiphanes freed the temples of Egypt in the eigth year of his reign

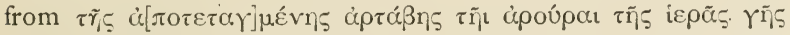

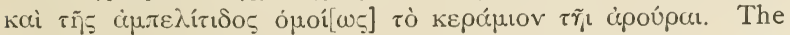
temples up to that time thus paid one keramion of wine per arura of vineland.

The Demotic ostracon D 45, published and translated in Theban Ostraca, Univ. of Toronto Libr., 1913, dating back to 102 B. C., is another document which shows that the vineyard tax was paid in kind. "Herakleitos, son of Aristippus, has paid for the rent of his vineyard in the cornland of Ophi, which was conveyed before Amonrasonther the great god, together with his wine for one vineyard two (keramion of) wine for his vineyard (and) for the ..... (of) the produce half a (keramion of) wine, making $2 \frac{1}{2}$ (keramia of) wine. They are received by reckoning(?). Written by ..... son of Khapokhonsis, year $15=$ year 12 , Thoth(?) day 25 etc." 3 .

In the well known comparison, the prophet Isaiah speaks of the laying out of a vineyard (כר) in Palestine. For the vineculture a sloping tract of ground was selected ${ }^{4}$. Care was taken to rid the ground from the superabundance of stones ${ }^{5}$. This was a task which the Hebrews could undertake to do even during the Sabbatical year ${ }^{6}$. According to Pliny ${ }^{7}$ the

I See Wilcken, o.c., pp. I50 and I5I.

2) Petr. Pap. II, I3, I7.

3) I follow the translation of Thompson, but change the word "garden" to "vineyard". $K m$ has both meanings.

4) Is. $5, \mathrm{I}$; Jer. $3 \mathrm{I}, 5$; Amos 9, I3 ; Jo. $4, \mathbf{1} 8$; Ps. 8o, II etc.

5) Mishna, I, 6; Is. 5, 2 (3) (2). 6) Mishna, Shev.

7) Hist. nat., XVII, 35. The wine gained from low growing vines was superior to that gained from vines trained on espaliers. 
Palestinians cultivated on the mountain slopes generally a low growing vine. Vineyards were, however, also planted on lowland (מקוה, plain), for instance, in the plain of Yisreel ${ }^{1}$, the plain of Sharon ${ }^{2}$ and probably also in the Negeb ${ }^{3}$. The vineyards were surrounded with hedges ${ }^{4}$, or walls, sometimes probably with both ${ }^{5}$, in order to protect them against the wilc animals ${ }^{6}$ and the pasturing cattle ${ }^{7}$. Sometimes vineyards were simply surrounded with thorns, cf. Jesus Sirach, 28, 24a „Thot fencest in thy vineyard with thorns". In the vineyard either simple huts 8 , or watchtowers" ${ }^{9}$ were erected. The latter consisted of a square building of solid masonry. The tower sometimes reached a considerable size, rising to the height of forty feet. The top-story contained several apartments, with suffi-

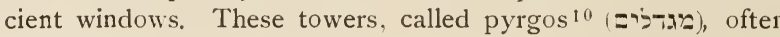
contained on the ground floor a stable and the wine-press The lower portion of the tower had also a small door anc a few narrow windows at a considerable height from the ground. The pyrgos was used as a dwelling place of the vinedressers 11 , or the guardians of the vineyard 12. Great care was taken to weed the ground ${ }^{13}$. According to the experience of the Hebrews it was harmful to the culture of vines to sow other plants between the vines and this was legally for bidden ${ }^{14}$, although it was the custom of antiquity ${ }^{15}$. In Rab binic time, however, it was permissible to raise other crop: between the rows (M'Orla 3, פרב :טרע ירק 8 ). While Pliny testifie: to the culture of low growing vines, the Hebrews certainly knev also of the practise of training the vines to wooden poles trellis work of cane-reed and to trees ${ }^{16}$. They often proppec

I) Jdg. 9, 27; L. Kings 21, I ff.

2) According to the Talmud.

3) See Palmer, Wïstenwanderung Israess, pp. 27 I ff., 283, 286, and 239

4)

7) Is. 7,25 ; Jer, I2, Io. Cf, also Sir. 36,30 "without a hedge the vine

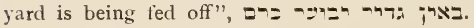

8) Is. $1,8.9$ 9) Is. $5,2$.

Io) Matth. 21, 33; Mark. I2, 1. II) 2. Chron. 26, 10.

I2) Job 27, I8; Cant. I, 6; 8, II ff.

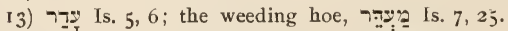

I4) Deut. 22, 9. I5) Pliny, h. n., XVII, 2 I.

16) Mishna, Kilaim, Bava-Bathra and Bava-mesia. - The fruit of th low growing vine matures earlier than that of the trained vines. But th 
the poles with long sticks and drew them together, binding them with willows'. Generally cane-reeds, but sometimes also more expensive wooden staves (†יר i. e., Sokáptov), which were pointed below and notched above, were used for espaliers. The vinestalks, that were raised on espaliers, stood in straight, sometimes also quadratic rows. In order to get a straight line, a cord (חויה) was stretched alongside the vines and the branches were entwined on the stalks and the cord. The vineyard was plowed two to three times a year, or worked with the hoe?. The foliage was carefully pruned and the superfluous shoots broken off ${ }^{3}$. The vines were often multiplied by means of props ${ }^{4}$, but the Hebrews must certainly have known also the way to propagate the vines by means of shoots. Only the latter practise would explain the acquittal from military service, which would have taken on too great proportions, if such acquittal had been given to every one who had made some props or who had made a layer, in order to replenish the gaps caused by the withering of the old vinestalks. It seems clear, that this acquittal could only be granted to those, who actually had planted a new vineyard, for which they, of course, needed shoots ${ }^{5}$. In some instances vineyards were attached to the houses of a city or village. These vineyards were greatly prized as being accessible and enjoyable at all season: of the year ${ }^{6}$. Those vineyards which lay a considerabie distance off from the villages, contained not infrequently a summer cottage for their owners. The family would commence to occupy it in spring, at the time of the digging of the vineyards and again later at the time of the vintage. The custom of remaining throughout the summer season in these cottages also prevailed ${ }^{7}$. The cutting of the vines was for-

climbing vines produce a much larger fruit, which also keeps longer on account of the thicker skin.

I) Mishna, Kilaim.

2) Is, 5,6 .

3) Is. 2,$4 ; 5,6 ; 18,5 ; \mathrm{Mi} .4,3$.

4) Mishna, Kilaim.

5) The fact, that he who planted a new vineyard, should be free from military service until its dedication, which occured possibly at the fourth year (Deut. 20,6), shows the high estimation of the Hebrews for the culture of vine.
6) I. Kings 2r, I.
7) Amos 3, 15 . 
bidden in the seventh year, but the cleaning out of the vinebranches was permitted ${ }^{1}$. This was really a piece of bad legislation, because the vinestalks exhausted themselves by over-production and they were much harder to cut in the following year.

The preferred kind of grape seems to have been the dark blue grape, which furnished a dark red wine. This is indicated

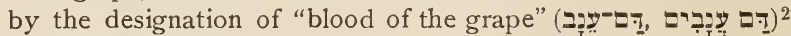
for the grape-juice. Another indication that the inhabitants of Palestine cultivated particularly the red or dark blue grape vines is the name ${ }^{3}$ or ${ }^{3}{ }^{4}{ }^{4}$ for a special wine, which undoubtedly received its name from its red grapes. Later, however, the cultivation of the white grapes superseded that of the red and dark blue grapes. At what time this change took place is hard to tell but with the beginning of the Middle Ages the export of Palestinian wines was that of white wines. In the vicinity of Jerusalem, of the two kind of Tabuke-vines, the one bears white grapes, the other dark blue grapes, Only the latter, together with the white Dshendale-grape, are used for the making of wine, while the white Tabuke grape is eaten ${ }^{5}$.

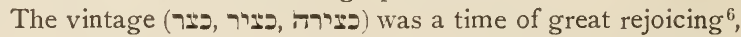
as in all wine-growing countries. But this festive, joyful mood is much greater in the Orient than in Europe, where early frosts often disturb this joy. In the Orient after the blazing summer heat generally follow beautiful days, which greatly help to make the time of the vintage the most favored season of the year. The inhabitants of Shilo celebrated at the end of each year

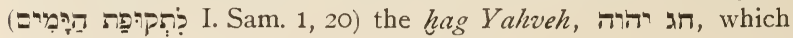
was the old festival of the gathering of grapes and olives. It developed later into a general harvest festival, the הג האיר at which the young girls used to perform dances. This festival of Shîlo was not merely of a local character, but accord-

I) Lev. 25,5 .

2) Gen. 49, I I ; Dt. 32, I4; comp. Gen. 49, I2; Is. 63, 2 ff.; Prov. 23, 3 I ; Sir. 50, I5; I. Macc. 6, 34; Matth. 26, 27 ff.; Apoc. I4, I9 ff.

3) Is. 5, 2; Jer. 2, 2 I. 4) Gen. 49 , II.

5) Anderlind, Die Rebe in Syrien, insbesondere Palestina, ZDPV, XI, p. 161 .

6) Judg. 9,27 ; Is. 16, I0; Jer. 25,$30 ; 48,33$. 
ing to I. Sam. 1 people attended it from far and near. The time of the grape harvest is in the month of September and part of October. Burchard of Mount Sion (1280 A. D.) ${ }^{1}$ informs us of the marvellous vintage in Antaradus thus: "But I have seen a wondrous thing at Antaradus, for there the natives told me that from one and the same vine grapes are gathered thrice in a year, in the following manner. In springtime the vine-dressers see when the vine has formed as many. bunches of grapes as each vine and each branch usually does; then they straightway cut off all that remains of the branch beyond those bunches, and throw it aray. This is done in March. In April a new branch sprouts from it with new bunches of grapes. When they see this they again cut off all of the branch that reaches beyond these bunches of grapes In May the trunk puts forth a third branch, with its bunches of grapes, and thus they have three sets of grapes, which all grow alike; but those which budded in March are gathered in August, those which budded in April are gathered in September, and those which budded in May are gathered in October. Thus they have three vintages in one year".

The eating grapes, however, are gathered somewhat earlier, commencing with August. At some places as for instance at the sea of Tiberias and at Ror the grapes commence to ripen even as early as June. After the vintage the old Canaanitish inhabitants of Palestine used to celebrate their fallfestival ${ }^{2}$, which was their New Year festival. Every stranger was allowed to eat grapes until satiated in the vineyards, but he was not permitted to take any grapes along on his jour$n^{3}{ }^{3}$. The vineyard owner, on the other hand, was not permitted to clean and pick up the grapes that had fallen to the ground. These had to remain to be gathered by the

I) See Pal. Pilgr. T. S., Vol. XII, pp. $89 \mathrm{ff}$.

2) So the Canaanitish inhabitants of Sichem, Judg. 9, 27.

3) Deut. 23, 25. - According to Jos. Ant. jud. 4, 8 an old custom was to offer grapes to the passing traveler. This generosity later ceased on account of the great number of travelers. Also the state fiscus claimed a large part of the produce of the vineyards in later times, which naturally tended to curb the old-time liberality. 
poor ${ }^{1}$. The vine-dresser (כיזר) cut the grapes (עקוץ) with a special knife (מזמרות), as was the custom in Egypt. In order to protect the grapes from falling to the ground during the time of the vintage, large baskets (כלכלה) were placed below the vinestalks. The grapes, which were not used for the making of wine, but were used as raisins, seem not to have been stripped by the Hebrews from the stems, but were dried in the bunch, as is the present custom in the district of Malaga in Spain ${ }^{2}$. The grapes, which were sold as eating-grapes on the market (כזר לשוק) were generally of the white color.

The grapes were carried to the winepress in baskets,

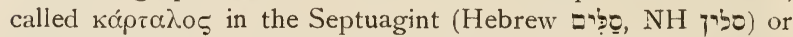
in vats (קוקט). The winepress (gath, $\boldsymbol{\Omega}$ ), was situated in the vineyard. It was sometimes covered by a roof ${ }^{3}$. The considerable size of some presses can be gathered from the fact that Gideon was able to use it as a threshing floor, in order to conceal his wheat from the marauding Midianites. The winepress consisted of two, and sometimes three or four, vats which were cut into the rock of the mountain. The vats were either round or angular, or the pressing vat (pîra,

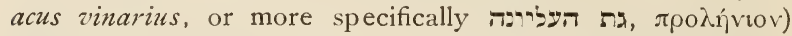
was angular and the lower vat (yeqeb, כיקר,

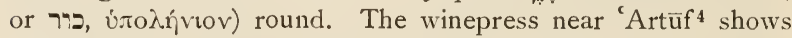
the pîra in angular form, with two yeqebs also angular, but a fourth and lowest vat had a round form. The pressvat reached a diameter of up to four meters. The winepress at Tell el-Hessy ${ }^{5}$ exhibits mud-walls, while its flooring is cemented and sloping slightly to a hollowed stone, which was placed in the cement. Prior to pressing, the pirra and the yeqeb were carefully washed and cleansed. In Rabbinic times the grapes used to be pressed by men (דרוכרו) hired especially for this work. In the pirra the grapes were trodden with the

1) Num. 19, 10. Cf. also Sir. 36, 16a and 30, 25 (Smend, Die Weisheit des Fesus Sirach, Berlin, I906) "And I have come as one who had tarried ong, like one who gleaneth behind the gatherers of grapes".

2) I, Sam. 25, I8; 30, 12; II. Sam. I6, I; I. Chron. 12, 40.

3) Judg. 6, II,

4) Schick, 'Artaf und seine Ungebung, ZDPV, X (1887), pp. $146 \mathrm{ff}$.

5) Bliss, A Mound, p. 69. This winepress belongs to the XIII th cent B, 


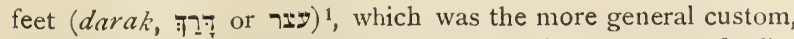
or by means of laying heavy stones on the grapes, or finally, by means of levers. The pressed wine flowed from the pura into the yeqeb, which was connected with the pirra by a channel (רצמב)). Whenever desired, this channel could be stopped up (FPD) in order to get a closed vat called $ת$ ג פקי Wherever there were more wine-vats, the first served the purpose of letting the pressed wine settle the lees ${ }^{2}$, and then the clarified juice was allowed to run into a second vat. The grape-juice was then poured into jars ${ }^{3}$, or into skins ${ }^{4}$. It was allowed to ferment in them, which commenced within six to twelve hours. It was also laid for some time on yeast. Then the new wine was poured into other jars or skins. The wine at that stage was called "yeast-wine" ${ }^{5}$. According to Luke, 5, 39 by this procedure the wine grew milder. Sometimes they waited until the next year, when the second fermentation set in, in order to transfuse it into other jars or skins. The wine was filtered before being used (פְְ

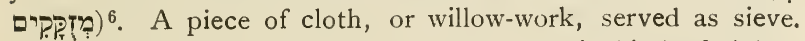
For this purpose in Rabbinic times a certain kind of siphon was used which consisted of a long and a short hollow glasstube. They were put together at an oblique angle, while a hole was permitting communication with both. One end of the siphon was placed into the full wine-jar and the second into the vessel or wine-skin into which the wine was desired to flow. The wine was drawn (העלה) from one vessel into the other with the mouth being placed at the hole of the bend. This kind of siphon seems to be identical with the

I) Is. 16,$10 ; 63,2 ;$ Jer. 25,$30 ; 48,33$.

2) In Talmudic times, and probably much earlier. the skins ard the grape-seeds, which renrained at the bottom of the vat were formed by hand into loaves or balls. According to their form they were either called "bread"

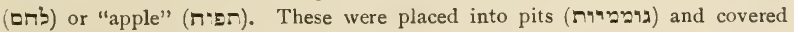
with boards, on which were placed heavy clay-rollers (גורזין), which had the form of a mill-stone. The pressing-beam (מרוחי) finally was lowered and pressed against the boards, causing the juice that remained in the lees to flow forth. See Krauss, S., Talmudische Archäologie, Band II, pl 235.

3) Jer. I3: I 2 ff., 48, I I.

4) Jos. 9, 4, 13; Job 32, 19; Matth. 9, 17.

5) Jer. 48, I I ; Zeph. I, I2; Is. $\mathbf{2 5}, 6$.

6) Is. 25,6 ; Jer. 48,1 I. 
so-called Sußipins of the Greeks. A more simple siphon was called "the sucker" (fem.) (מינק). The task of transfusing

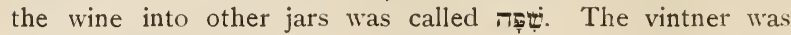
called "w.

In 1909 the German expedition, excavating on the site of ancient Jericho, disinterred a house which brought to light a wine cellar of the Jerrish period. This cellar was situated in the Northern corner. Four large wine amphoras stood side by side on the ground towards the southwest corner of the cellar-room. Three of these amphoras were well preserved. On top of two of these amphoras lay a large two-handled plate with spout. A large four-handled amphora was found broken in pieces before the north wall. Amphoras, plates, large and small jugs, a sieve and a spindle-whorl in the debris were discovered. They hung probably to the wall on wooden plucks or were placed on wall-boards, according to Sellin, since these vases were found somewhat higher in the debris. This room possessed especially strong inner walls. It was accessible by means of a stairs, which led down to the cellar ${ }^{1}$. King David placed special overseers over his wine cellars (7:3) When the wine was presed and brought to town, in order to be put into the cellar, it was subject to the tax. The tax-gatherers met the wine-pressers at their entrance to the city-gate and levied the accustomed tenth part ${ }^{3}$. The wine was stored in the cellar either in clay-bar-

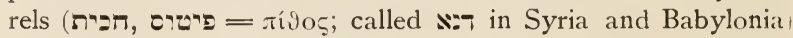

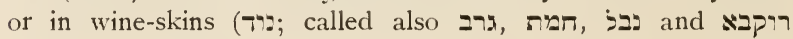
according to their form), or finally in jars, pointed at the bottom, in order to be placed into the ground. These pointed jars seem to have been out of use in Talmudic times. The wine-skins were kept closed by means of pieces of bone, which were wrapped either with bast or papyrus, or were simply tied with a cord (פיס). The clay-barrels had stoppers of clay, lime, pitch or gypsum, but sometimes a piece of leather or cloth or papyrus was simply placed over the mouth of the cask. As soon as the barrel or the wine-jar

1) Sellin, fericho, p. 77 .

2) I. Chron, 27, 27 .

3) I. Sam. $8,{ }_{5}$. 
was closed, it was sealed and the name of the owner and the quantity and quality of the content attached in writing.

Babylonia has left us no monuments, which would illustrate the laying out of their vineyards and the process of making grape-wine. But we may conjecture that in the lowland of Babylonia viticulture was essentially the same as in Egypt, where conditions were very much alike, and that it differed from that of Syria and Palestine. We had occasion to refer above to the vineyard planted by Gudea, and we found that this vineyard was planted on an artificially raised plot of ground. This practise, probably, prevailed all over Babylonia. Vine, however, was never extensively cultivated in that country and the documents refer comparatively seldom to wine, while they mention very often fruit-wines, such as date-wine, and particularly a multitude of different kinds of beer. It is strange, however, that at the earlier stages of Babylonian history, we never hear of "beer-houses", but that the Code of Hammurabi, for instance, refers only to wineshops. We will have occasion in Chapter Four, to enter into a detailed account of that part of Babylonian legislation, which deals with the wineshops. Contrary to Babylonia, Assyria cultivated the vine very extensively, in the vicinity of Nineveh as well as in other parts of the land, since the vineplant grows well in many districts of Assyria. The Assyrian monuments represent the vines very realistically and with a great deal of truth (see Illustrations Nos. 13 and 14). In the Assyrian documents there is mention of an officer called ràb karâni. This title represents the "Chief winemaster", and the office may refer to a state position as well as to a position held in the service of some large temple. Tablet K. $342 \mathrm{a}$ und $\mathrm{b}^{1}$ is important for our present investigation, since it mentions not only the chief winemaster, but also his assistant called $a n \hat{\imath} l u \grave{s} a n \hat{u}$, i. e., the second (winemaster). The text, moreover, deals with a transaction, in which

I) (I) kunuk m.Zêru-u-ti ràb karâni (2) kunuk m. arbuuUlûla-a-a amêlušanût: (3) 9 manê 15 šiḳil kaspu (4) ina I manê ša âlu Gar-ga-miš (5) gi-nu-u ša Ašur šur (6) ša m.Ašur śur-rêšu-i-ši (7) ina pân m.Zêru-ti ràb karâni bîti ešši (8) ina pân m. arbuUlûla-ia-a amêlu šanûu (9) arbuSîmânu ûmu 16-kam (10) limmu m.Ša-iluNabû-šú-u amêlu rêšu(?) etc. The text is translated in Kohler and Ungnad, Assyr. Rechtsurkunden. 
money is paid in order to obtain wine for sacrifical purposes. Amongst the witnesses two are of special interest, namely Marduk-ibni, the amên šâk $\hat{u}$, that is the "beer-house keeper", and Mutakkil-Ashur, the sim +gar, that is, the brewer. The

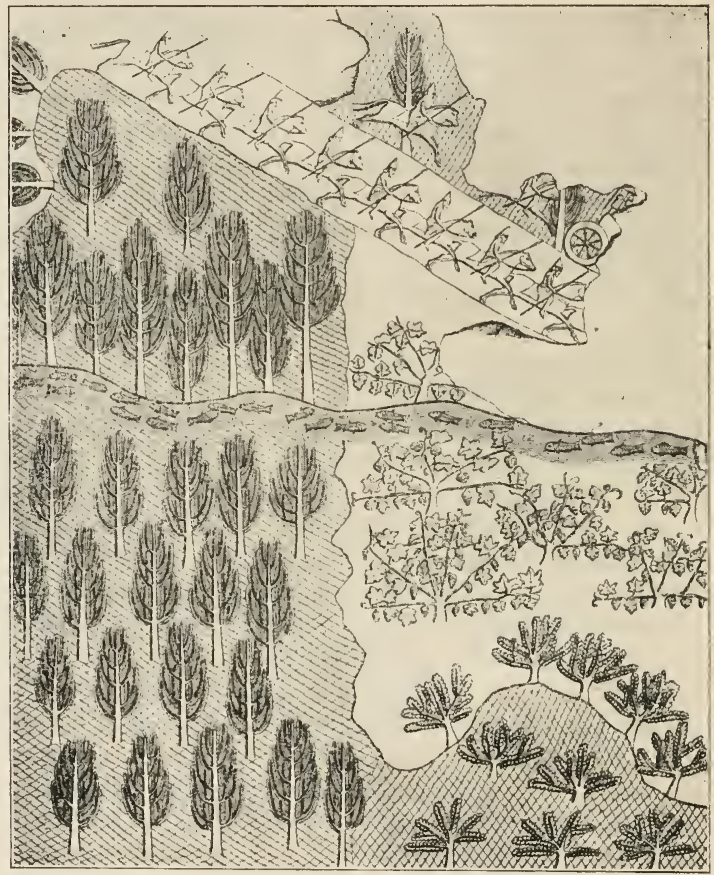

Nio, 13. Bas-relief of Nimrûd (Calah) in the British Museum (after Lenormant, Fr., Histoire ancienne de l'Orient).

tablet reads: "Seal of Zêrûti, the chief winemaster, seal of Ulûlâ, the second (i. e., the assistant winemaster). Nine minas, fifteen shekels of silver, according to the mina of Carchemish, sacrificial offering of the god Ashur, belonging to Ashurrêshu-ishi, at the disposition of Zêrûti, the chief winemaster 
of the New House (and) at the disposition of Ulûlâ, the second (winemaster). The 16 th day of Sivan, in the eponymate of Sha-Nabû-shû, the chief-officer etc."

The pressman was called sircušu. He not only pressed the wine and filled it into kegs or wine-skins, but also retai-

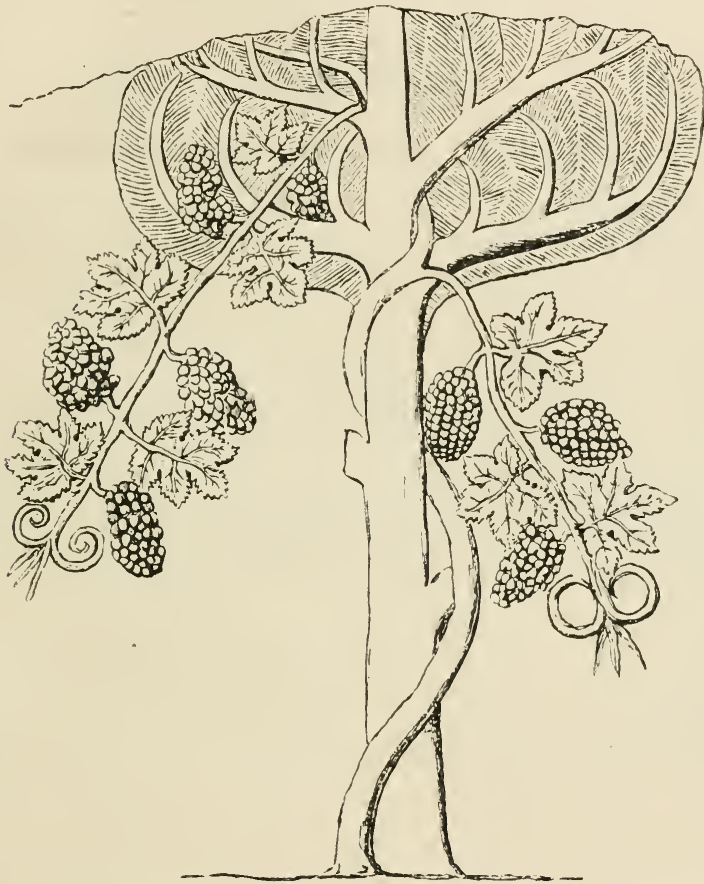

No. 14. Climbing vine of a bas-relief in the palace of Sennacherib at Kuyunjik (after Lenormant, Fr., Histoire ancienne de l'Orient).

led it. In CT XXII 38, 9 a Neo-Babylonian temple-official informs his master, a priest of Sippar, that "the wine has been pressed in my presence". The manufacturer of spiced wines, according to Oriental custom, was at the same time a perfumer (see Meissner, Babylonien und Assyrien, p. 242). 


\section{Chapter Three}

\section{The Beer in the Ancient Orient}

Peoples in all ages and climates have prepared naturally fermented beverages from any available material. The statement of Pliny 1 "if any one will take the trouble duly to consider the matter, he will find that upon no one subject is the industry of man kept more constantly on the alert than upon the making of wine", can be augmented by the addition "and of beer". The brewing industry in its beginnings in historic times was a home industry like that of baking bread. Indeed the work of the baker and that of the brewer was very much alike in the initial stages of brewing. The earliest Egyptian texts enumerate quite a number of different beers. One of the oldest generic terms for beer seems to be sehpet, 的. Shptbeer Pyr. Texts W I 43 a; T 1 I 4 a; N 451 a; Beni Hasan I, pl. 17 etc. On the stele of Khabiousokari in the Museum of Cairo a certain beer is called $h n^{-}$, a "dark beer", an "iron beer" and the hes-beer, i. e., "garnished beer" ${ }^{2}$. The pyramid-texts further mention the ph-beer, $\frac{\square}{}$, (W $144 \mathrm{a}$; T $115 \mathrm{a}$; N $452 \mathrm{a}$, which is probably the same as the ph'-beer, 10 , in Beni Hasan I, pl. 17), the num -beer (W $141 \mathrm{a} ; \mathrm{T} 112 \mathrm{a} ; \mathrm{N} 449 \mathrm{a}$ ) and the beer of Nubia, hk.t sty, $\quad \& \circ\}(\mathrm{W} 145 \mathrm{a} ; \mathrm{T} 116 \mathrm{a} ; \mathrm{N}+53 \mathrm{a})$. Under the rubrique sehpet, "beer", are also mentioned very early the

I) Pliny, XIV, 22.

2) See Unas $46,53,54,55$. 
beverages 989] mmm (probably identical with the beverage cal-

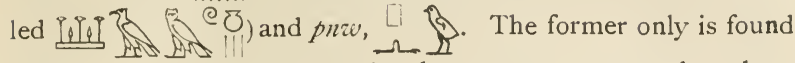
again by Hathorneferhotep in the same category, but there it is again mentioned under the heading of liw.t, \& 80 , and of $m m$ s.t, d 0 , ? d o. Probably these latter two names refer also to certain kinds of beer ${ }^{1}$. Nms s.t may possibly be connected with the name for cellar, nmw, fon designation of a beverage, which was kept in the cellar. In the Egyptian bazaar-scene ${ }^{3}$, dating back to the fifth dynasty, the second row shows a woman offering for sale a beverage, which bears the name nmist, mm kneels before a parfume vase. The woman is saying to him. "It is $n m$ s't that satisfies thee", nm I The liquor is contained in two white bowls, which she extends towards the prospective buyer. This market-scene is of interest, since it show's that even at that early time liquors were sold by women in public places. In Dümichen, Kal. Inschr., 46, 1 appears a certain kind of beer, called

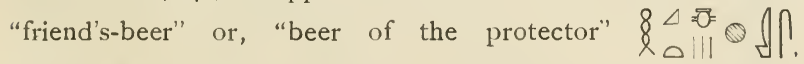

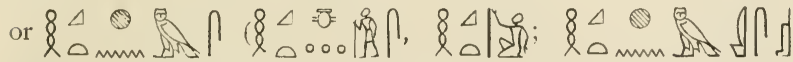
Beni Hasan I, pl. 17), hk.t hnmis, which was probably an old beer, or lager-beer. Sweet beer is mentioned, f. i., in Med,

I) Weil, Raymond, Des monuments et de l'histoire des II et IIIe dyn. igypt., Paris, I90S, pp. 249 and 253.

2) The $n m w v$ is a cellar in which any kind of beverages were storel.

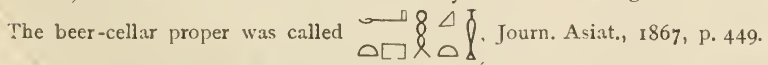

3) LD II, 96 and Maspero, Bibliothèque Égyplologique, VIII, (1900) plate facing p. 256. On the element $\Longrightarrow \rightleftharpoons$ beverage, see above, p. 79, n. I.

4. Mistake ior $p i \omega$, If. 


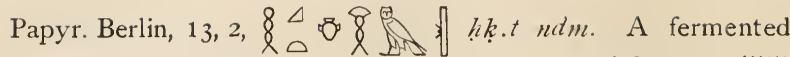
liquors appears in Papyrus Ebers under the name $\|\left._{0} \cap\right|_{D}$ mm

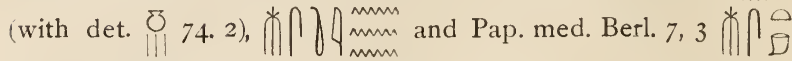
3 e 8 for 7 ?), which is 1. 6 is a special beverage, while for "drink, beverage", Hadad 9. For a reference to the beverage called dwize, $\sim 4$ see Budge, Book of the Dead, p. 367,3 and 382,5 . The latter passage reads: „The beautiful West-land, in which the gods live upon cake and dz'i-beer",

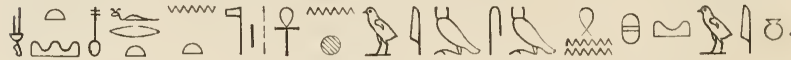
The following five beverages, whose names we register, may either denote certain kinds of beer or wine; hbt, \& $\int_{0}^{0}$,

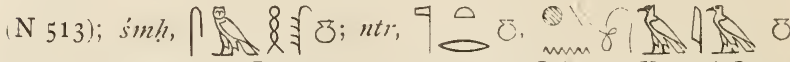

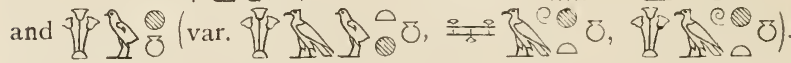

The commonest beer was prepared trom barley; of which grain two kinds have been found in Egypt, the hordeum hexastichum $\mathrm{L}$. and the hordeum tetrastichum Kche. The former was the most common grain in Egypt ${ }^{1}$. The barley

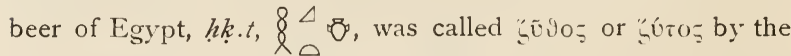
Classical writers. This name " $v i o z$ is found for the first time in Theophrastos ${ }^{2}$, who reckons it to those beverages, which were prepared, like those made of barley and wheat, of rotting fruits. Herodotus states ${ }^{3}$ oî

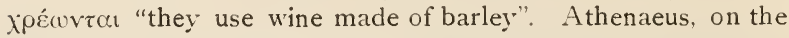
authority of Hecataeus, mentions the fact "that the Egyptians were great bread-eaters, eating loaves of rye, called kvitip-

I) Schweinfurth, in Wissenschattl, Veröffentl. der deutschen Orientgesellschaft, VIII, p. 153. See also Unger, Sitzungsber. d. Wiener Akad., math.nat. Klarse 54 r, p. 4 r.

2) Theophr., de $c . p l .$, VI, II, 2.

3) Hetod. II, 77; see also Diod. I, 3t; Strabo, XIII; Pliny XXII, 25 , Athen., X. 


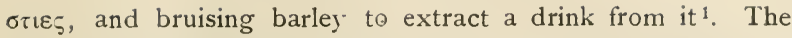

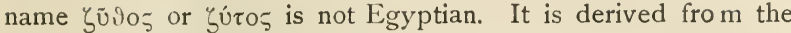
verb $\zeta \hat{\varepsilon} \omega$, an old Greek word, as old as Homer and Hesiod. $\zeta \varepsilon ́ \omega$ means "to boil", "to foam" and the Greeks applied it to

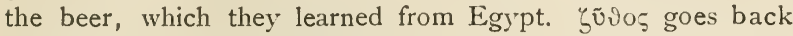

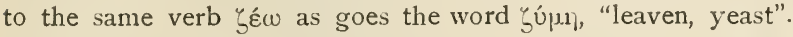
According to Diodorus ${ }^{2}$ the $\zeta \tilde{v} \vartheta \circ \zeta$ was considered an invention of Dionysos, while according to the same writer ${ }^{3}$ Osiris made it known in those countries where the wine does not grow. The beer constituted an indispensable beverage in those parts of Egypt, in which the vine did not grow. It was the drink of the peasant, the shepherd, the sailor and the fisherman. It is stated ${ }^{4}$ that it was nearly as good as wine, but the Greeks despised the Egyptians, who drank a beverage which was prepared from barley ${ }^{5}$. Dioskorides taught that zythos causes urination, affects the kidney's and the nerves, endangers the brain membrane, causes bloating, bad phlegms and elephantiasis. Since the zythos was a product of decayed materials it caused bad phlegms ${ }^{6}$. The best that is said about it by the Classical writers refers not to its use as a beverage, but to its property of softening ivory, which made it possible to bend the ivory into any desired form. This property of the zythos was due to its element of acid. Since hops were unknown to the Egyptians as well as to all the ancient Oriental peoples, they were obliged to have recourse to other plants, in order to improve the taste of the beer and to keep it for sa longer period of time. The lupin (lupinus termis Forskal; Arabic termus), the skirret (siser; the sium sisarum L.) and the root of an Assyrian plant were used by them for that purpose $^{7}$. In Hellenistic times Egyptian beer was imported

I) Athen., $\mathrm{B} \mathrm{X}, \mathbf{I}_{3}$.

2) Diod. IT, 2 .

3) Diod. I, 20.

4) Diod. I, 20.

5) Aesch. Hik., 953 .

6) Orib. XV, 1, 6, 6. Gal. Aet. The Greeks also considered, strangely, the barley beer as being the direct cause of leprosy.

7) Columella, de cultu hort., X, 114-116: "iam siser, Assyrioque venit quae semine radix sectaque praebetwr madido satiata lupino ut Pelusiaci proritet pocula zythi". This passage is, however, understood by some scholars in suite a different way. They say that it refers to the previous eating of $\mathbf{r a}$ dishes and lupins, in order that they should arouse the appetite for drinking: 
into Palestine, probably from Pelusium, which seems to have been the most noted city for its beers in Egypt. Pelusian beer was also exported to Rome ${ }^{1}$.

The Egyptian word for "brewing beer" is "th, The name for the brewer is ' $f t y$, (Leiden, Stele V, 6)

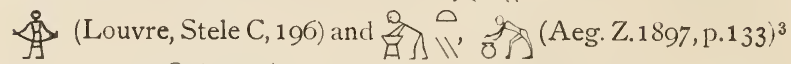
or also -0 The brewery, which was a special part of the kitchen, is called "the pure", / $\mathrm{I}^{4}$. Beer, according to the Egyptian texts, is either prepared from barley, it, $4_{0,0^{\circ}}^{\circ}$ Coptic ElWT, of which three kinds were distinguished: the white, black and red barley or of spelt, bd.t, $\int \underset{\text { * }}{\longrightarrow}$, Coptic BWTE. Barley beer was the most common beverage, the national drink of Egypt. Besides the name it, $\bigcup_{000^{\circ}}^{0}$, the texts mention another name for

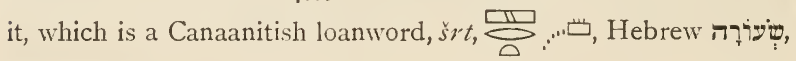

de Sacy, Chrest. Arab. I, p. I79: "Dans ces vers.... je n'aperçois autre chose que la coutume où l'on étoit de servir à table du chervi et de la racine dont parle l'auteur, macérée dans des lupins en fermentation, pour exciter les convives à boire de la bière." Cf. Hor. sat. II, 8, 8; Diosc. II, I $\hat{3}^{2}$ and Pliny XXII, 155. This may, after all, be more correct, since we should expect otherwise a similar practise in Babylonia, where we do not find bitterplants added to the beer. - See also Sprengel, T'ersuch einer pragmatischen Geschichte der Arzneikunde I, p. 75.

I) See Col. Econ. X, 4, I14.

2) Aeg. Z. 42, p. 27. Gardiner, Hymns to Amon from a Leiden Papyrus: $\longrightarrow$ ○ the day of festival".

3) See Aeg. Z. 1896, p. 161; see also Newberry, Beni-Hasan I, pl. 29 $=$ L. D., II, 126. For a reference to a female brewer, Aeg. Z. 1897, p. 123.

4) Pap. Anast. 4, 16, $3 \Rightarrow$ Pap. Anast. 3, 8, 5 . 
Syriac $12 i s \infty^{1}$. It is probable that whenever this latter word is used, it refers to an imported kind of barley, which came from Syria, according to Pap. Harris I².

The word $h k t, \& \triangle \delta$, is most likely derived from the root

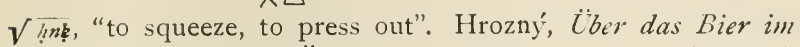
alten Babylonien und Ägypten (Anzeiger der Wien. Ak. phil. Cl. 1910, Dez.), connects hkt with the Babylonian beer called hîqu, deriving the word from hâqu, "to mix". It is hardly possible to suppose, apart from other considerations, that a word like Egyptian hlkt, which occurs innumerable times in texts of every period, should have been borrowed from the Babylonian hîqu, a word, which is not at all met with frequently in Babylonian texts. Certain beers used for religious purposes exclusively were called 84840 舟 T 288; M 65; with the determinative 80840 急 $-\frac{1}{3}$ 3o ${ }^{3}$ 126, i. e., "beer which does not sour(?)"; $8 \Delta_{8}$

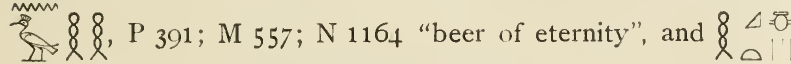
$\Rightarrow=0$ ? of truth". The latter was a beer drunk by the 12 gods who guarded the shrine of Osiris.

Durra-beer seems to have been unknown to the Egyptians until a very late time. Pliny's statement ${ }^{3}$ that the durra was brought in his time from India to Italy may be correct and explain the fact that the Egyptian inscriptions do not

1) F. i., Totenbuch, 173 "beer of white šl". Aeg. Z., 1877, 1). $3^{\circ}$

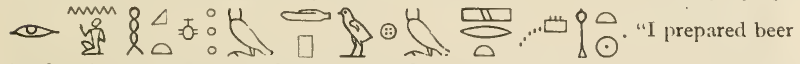
in the city of $T p n$ from white $s r t "$. White $s r t$ appears to have been preferred for brewing, while the black srt was more generally used for the making of bread. The white and red barley, called $i t$, are also more generally mentioned in the making of beer than the black it. Totenbuch 189,14 "bread of black barley (it)".

2) The chief barley growing district of Palestine was the soutbern part of the country.

3) Plin., $H, n$. XVIII, I7. 
mention it. An Egyptian word, which could mean durra, has never been found. See, however, Maspero, G., Bibliothèque Égyptologique, XXVIII, p. 252: "La dourah est originaire de l'Afrique tropicale, et j'ai cru la deviner sous le nom de Dirati, Dourati dans une lettre d'affaires écrite vers le milieu de la XIXe dynastie" (i. e., Pap. Anastasi IV, pl. 13 line 12 and

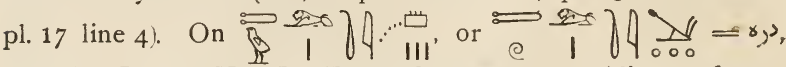
see also Loret, V., La Flore pharaonique, $2^{\mathrm{e}}$ édit. p. 26, 144. The word is generally translated: "fine flour", Hebrew sio

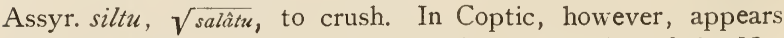
a word which may refer to the merisa, or merise of the Nubians, a beverage which is prepared from durra. If this is the case, it would still be a late evidence for durra-beer in Egypt. The Egyptian p3wr, tक $\overline{0}^{1}$ hardly equals Coptic мріс, Емпрıс, "mustum" ?.

Zosimus of Panopolis in the Thebais, a chemist who wrote probably before the time of Photios, has left us a description of the method of brewing beer amongst the ancient Egyptians. He says:

\section{About beer-making}

"Take fine clean barley and moisten it for one day and draw it off or also lay it up in a windless place until morning and again wet it six hours. Cast it into a smaller perforated vessel and wet it and dry it until it shall become shredded and when this is so pat it (i. e., shake, or rub) in the sun-light until it falls apart. For the must(?) is bitter.

Next grind it and make it into loaves adding leaven, just like bread and cook it rather raw and whenever (the loaves) rise, dissolve sweetened water and strain (it) through a strainer or light sieve.

Others in baking the loaves cast them into a vat(?) with water and they boil it a little in order that it may not froth nor become luke-warm and they draw up ( $=$ absorb) and strain it and having prepared it, heat (it) and examine (it) ${ }^{3 \prime}$.

I) Mel. III, p. 89 ff.

2) Brugsch, $W B$, Vol. VI, 467 .

3)

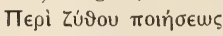

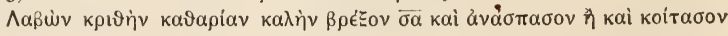


Ludwig Borchardt was the first scholar who explained the meaning of those pictures and statues which refer to the brewing industry ${ }^{1}$ in Egypt and who indirectly helped to understand also the Babylonian texts, which contain the earliest beer-brewing recipes that have come down to us ${ }^{2}$. A certain amount of grain, either barley, spelt or wheat ${ }^{3}$ is poured into a mortar and ground, after being moistened. After that yeast was added 4 and worked into the dough. On the east-wall of the tomb of Rahenem surnamed 'Isy ( -4$)$, at Deir el-Gebrâwi's we see the dough piled up in many earthenware vessels. Some of these vessels are taken by a man and stacked for baking (see Illustration No. 15! Below these vessels was then set a slow fire. The man, who is about to slightly bake the loaves in the vessels, is pictured shading his face from the heat. When the bread was half baked, it was broken into pieces and

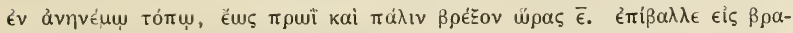

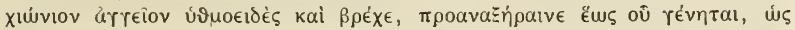

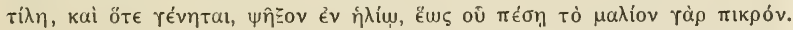

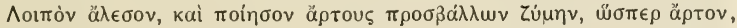

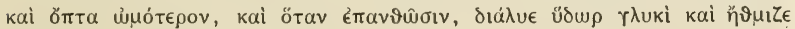

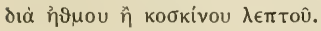

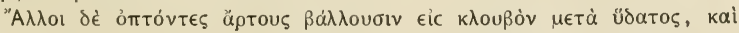

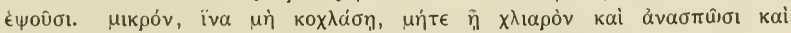

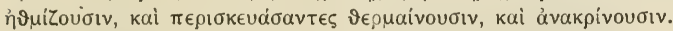

(Zosimi Panopolitani de Zythorum confectione fragmentum, ed. C. G. Gruner, Solisbachi, I814). See also Dioscor. II, rog aud nio.

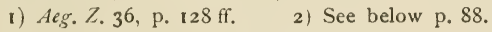

3) That sometimes also wheat was used is indicated in Theophrast., De

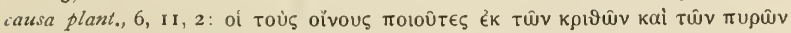

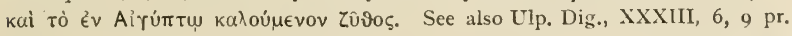

4) ी

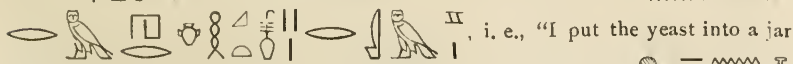
(and) the beer into the cellar". Another word for yeast is $\operatorname{mm} 8 \Delta \|_{0}$, , see Br., $W B$, Vol. VI, p. 660.

5) Davies, The Rock-Tombs of Deir el Gebrâwi, part II, pl. XX. 
soaked for several days. The bread pieces were then placed into a large fermentation-vat, which was large enough to hold a man or woman, and the soaked pieces were then trodden by the feet (see Illustration No. 16). A small statue ${ }^{1}$

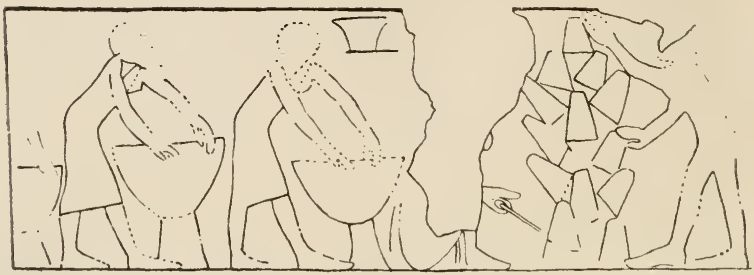

No. 15. Women soaking bread-loaves in large bowls; at right man staking loaves for slight baking (after Davies, Rock Tombs of Deir el-Gebrawi).

shows a woman standing in the vat, holding her hands at the top of the vat. In the painting at Deir el-Gebràwi we see the process, which was most characteristic to the Egyptians

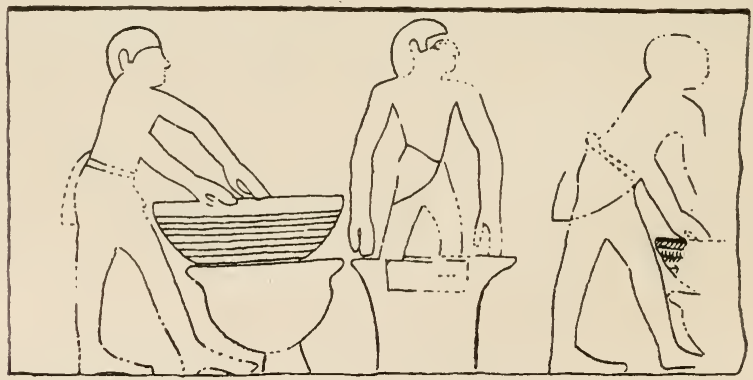

No. 16. Man in centre pressing the soaked beer-loaves in large vat. Men at left and right filtering beer through woven baskets over large bowls (after Davies) Rock Tombs of Deir el-Gebrawi.

for brewing, so that the hieroglyph "brewer" is taken from the act, performed by a man. In the latter painting the artist

I) Found in Neggada and preserved in the Berlin Museum; see Aeg. $Z$., I896, p. I6 I, illustrations 12 and 13 . 
has even gone so far as to show the yellow grains on the exterior of the vat, which is painted red. Next we see the sieving of the beer-mash. The semi-liquid mass is poured into a flat, wide-woven basket, in which we see sometimes one, sometimes two servants kneading the mass with both hands. The basket is placed over a large jar, which stands either in a turned over basket or in a foot-stand of basketwork. When the beer loares had been thoroughly kneaded and stirred, the liquid filtered through the basket into a large jar below, from which it was finally poured into the large beer jars. This work of filling the beer jars was called $m h$ h h In 8 8 $8 \triangle$ XIn Rifeh ${ }^{1}$ large conical bowls with a hole in the bottom have been found, which served the purpose of pressing and stirring the beer loaves, in order to squeeze out the fermented beer from the loaves. Petrie ${ }_{\wedge}$ notes that one still contained a pressed cake of barley mash and grains. In grave No. 29 were also found mud-models of vases with blue line pottery belonging to the end of the XVIIIth dynasty. Some of these vases were closed with mud caps, many of which still containing barley grain and barley mash. The persons represented as filling the beer bottles, are always seen sitting on the ground. One hand is inside the long bottle, while the other is holding it (see Illustration No. 17). It seems that before the bottles were filled with beer, they were smeared with bitumen or the like, as was done with the wine bottles. These bottles, when filled, were finally closed with large balls of Nile-mud.

A recipe to prepare Egyptian beer is also found in the Rabbinic literature, to which J. H. Bondi first called attention 2 .

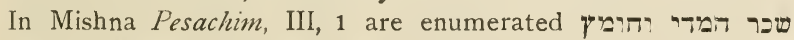
"Median beer and Idumaedn vinegar and Egyptian zythos". The Gemara (B. Pesachim 42 b) remarks that barley is put into the first two. It says regarding the Egyptian beer: "What is Egyptian zythos? Rabbi Joseph

I) Flinders Petrie, Gizeh and Rifeh (British School of Archaeology in Egypt and Egyptian Research Account, I3 th year, 1907), p. 23.

2) Aeg. $Z$, 33, p. 62 .

Lutz, Viticulture and Brewing. 
teaches: a third of barley; a third of safflower seed ${ }^{\prime}$ and a third of salt. Rabbi Papa took barley off (the recipe) and placed instead (of it) wheat ....... They moisten it, roast it, grind it and drink it from Passah unto the week-festival. It causes diarrhea to whosoever is costive, and whosoever suffers of diarrhea, him it makes cos-

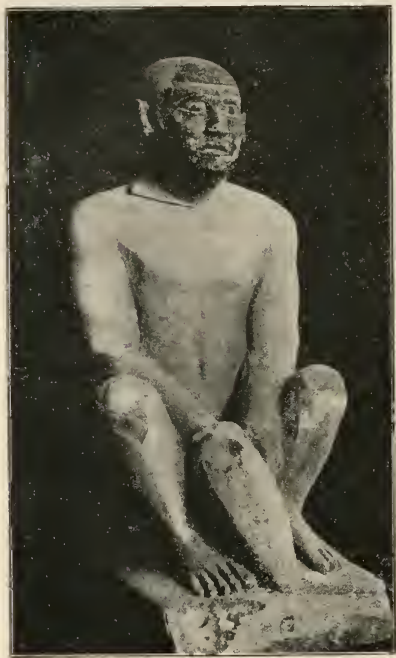

No. 17. Coating the interior of beer bottles with bitumen (after Aeg. Zeitschr. Bd. 35 ). tive. It is a danger for the sick and the pregnant woman" 2. The "foaming" of the beer was expressed by the word stf,

The Egyptians also imported beer. The greatest beer export country seems to have been along the Syrian and Asia Minor coast, which was known geographically as Qode, $\sqrt{\|}$. The Qode-

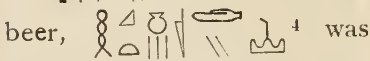
probably not a Syrian product, but came from inland, either from Babylonia, or more likely, from the Hittite country. Qode may be identical with the Biblical "coast of the Kittians", i. e., the coast-land which formerly reached from Cilicia to $\mathrm{Pe}$ lusium; cf. Solin. 38, 1: Ciliciam, qua de agitur, si, ut munc est loquamur, derogasse videbimur fidei vetustatis: si terminos sequimur, quos habuit olim, absonum est a con-

I) Carthamus tinctorius L., which grows in Egypt.

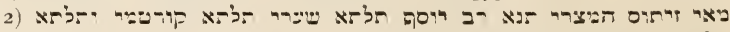

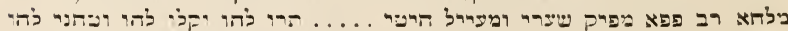

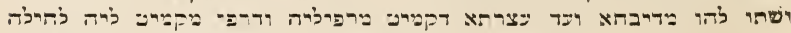

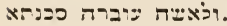
3) Pap. d'Orb. $8,6$.
4) Pap. Anast. 3 verso 2; 4, I2, II. 
templatione rerum praesentium. Cilicia antea usque Pelusium Aegypti pertinebat, Lydis, Medis, Armeniis, Pamphilia, Cappadocia, sub imperio Cilicum constitutis: mox ab Assyriis subacta, in breiciorem modum scripta. This beer played an important role in Egypt, where it was often imitated ${ }^{1}$. In a letter ${ }^{2}$, the writer, who was stationed in Qenqen-tane ${ }^{3}$ writes to his superior that the food at that place was bad and the best drink he could get was beer from Qode. Two kinds were known in Egypt, the imported ${ }^{4}$ and that which was brewed in Egypt by foreign slaves ${ }^{5}$. The genuine Qode beer was differentiated by the name $8 \begin{array}{lll}\Delta & 0.111\end{array}$ mи 4 (f) $\mid \sqrt{\square}$, i. e., "imported Qode beer". In Pap. Leid. I, 345, rev. G. VII is mentioned "a thirst, which empties the Qode

1) Hierat. Inschr. 5637 .

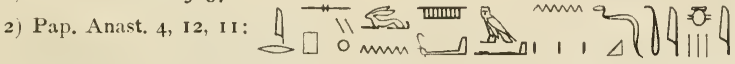

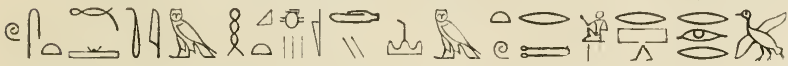

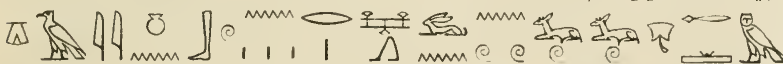
อгеm

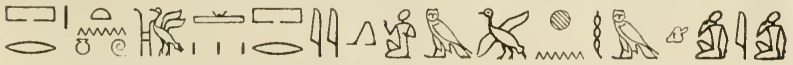

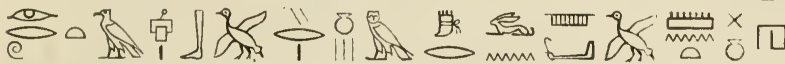
[1 गी i. e., "Sometimes when bottles are opened, filled with beer from Qode, then (?) the people go forth to make a drinking-bout outside. There are 200 great dogs and 300 jackals, 500 in all. They stay all day at the door of my house. Each time that I go out while they sleep, whenever the $n$ sck of the bottles is broken and when the jug is opened, I should be excluded, if I did not have the little jackal-dog of N'hr-hww, the royal scribe, who dwells with me in $\mathrm{my}$ house. It is he who saves me from them (scil. the $\operatorname{logs}$ )".
3) Location unknown.
4) P:tp. Anast. $3,3,6$.

5) Pap. Anast. $4,16,3 ; 3,8,5$. 
countries", which also indicates that Qode was the beer country

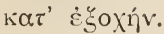

The inscriptions refer to an officer called "inspector of the brewery", 0 .

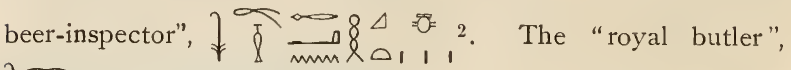
$\neq$, was a high court-official. In the representation of Wiedemann, Hierat. Texte, Tafel 8 (Pap. Louvre 3308) the 7 के stands behind the king with a fan. 7 of selon DHI $40 \mathrm{e}$; Mar

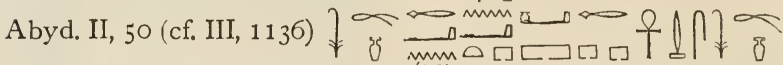

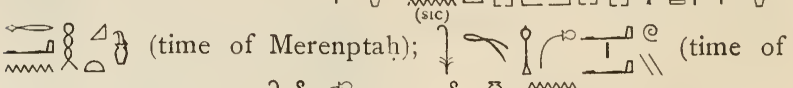

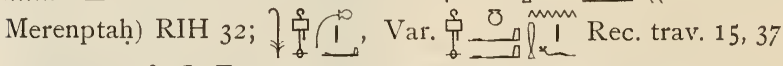
(Amarna); 吊 J D=

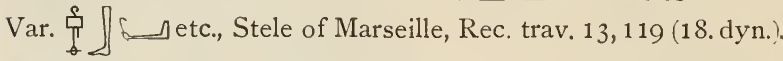
$8=3 \triangle \square$ ? 44 on a stele of the 12. dyn., ed. Wiedemann, Marseille. Next to butler the 0 if with bottles and jars, LD II, 129 (Hnmhotep). A servant, whose hair-dress seems to point to

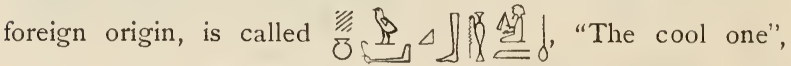
LD III, 242. For a graphic variant of the name "butler" (jug in bowl) from Bab-el-Moluk see Desc. II, pl. 85; similar Wilkinson, I, 425. For a good picture of the butler see Champ. mon. 434 . Characteristic are the sleeves and the double garment in the dress of the butler (see Mar. Ab. II, 49 and Champ. mon. 225). For the best and largest representation of the butler of Medinet Abu see Desc. de l $E_{g}$. II, 8 (smaller II, 10). The uppergarment is most likely a sleeve-apron, which the butler wore in order to protect his chief-garment. It is of interest to note in this connection that the pre-Islâmic Arabic waiter also

I) Stele $\mathrm{C}_{45}$ in the Louvre.

2) Stele of Ramessai-m-pr-rc in Bulaq. 
wore a kind of apron, or a woman's garment, of course for the identical purpose. Regarding the chief-butler of Pharaoh the שֶר הee Gen. 40, 2, 9, 20, 21 and 41, 9, Emperor Augustus is represented in the temple of Denderah as e d nm "

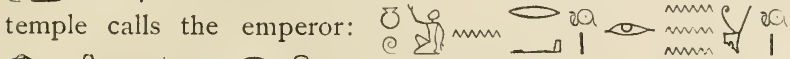

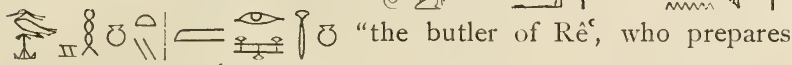
the drink for Rế, filling the vessels with "green Horus-eye"wine (see Dümichen, Die Oasen der Libyschen Wïste, p. 1 and plate XVII).

Under the Ptolemies and the Roman emperors the Egyp-

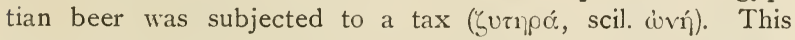
tax was paid by the producer, the sutoroióc. It was leased

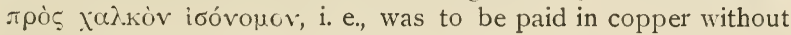
agio ${ }^{1}$.

The tax on beer played a great role in the finances of the Ptolemies and of Roman times. A papyrus in the British Museum ${ }^{2}$ refers to the taxation of a large brewery firm, named "Pasion and Sentheus". This text makes us acquainted with a brewery, which must have done a tremendous business, as the tax receipts show. For each month of the year the two brewers, who lived in the first century B. C., paid five copper talents, as pópo气, which according to Wilcken $^{3}$ is the tax for production.

The consumption of beer in Egypt for all periods of its long history must have been considerable. According to an inventory, for instance, of the income and the expenses of the royal court at Thebes, dating from the end of the Middle

I) Wilcken, Griechische Ostraka, p. 369 .

2) See Grenfell and Hunt, II, 39

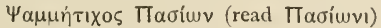

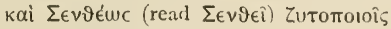

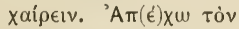

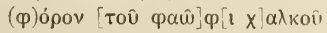

$[\tau \dot{\lambda} \lambda \alpha] v\left[\tau \alpha \quad \pi \epsilon^{\prime} v \tau \epsilon \quad\right.$ ik] $\epsilon$

['Eтous Bquîpl] ic

3) Wilcken, Griech. Ostr., p. 37 r. 
Kingdom (c. 1800 B. C. $)^{1}$ there were brought daily 130 jars of beer to the royal court, and the queen received on one day five jars filled with beer.

Egypt until recently, was considered the oldest beer country in the world. Since the last decades, however, from the materials published, we learn that Babylonia was not less engaged in the brewing industry than Egypt. The oldest evidences of beer brewing in Babylonia reach back to the very threshold of its history. The material is so large and so detailed that we are enabled to receive a pretty complete insight into the work of the Sumero-Akkadian brewer ${ }^{2}$.

The commonest beer (Sumerian: kaš, Akkadian šikaru) in Babylonia was, like that of Egypt, prepared from barley

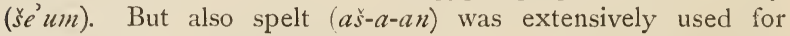
that purpose, and it is possible in some instances also wheat (se $G I G, G I G$, "se $G I G . B A$ ). Essentially the method of the SumeroAkkadian brewing industry differed very little from that of Egypt. We have seen that in Egypt beer brewing to a large extent was connected with the baking of bread loaves. In the Sumerian beer recipes which go back to c. 2800 B. C., we meet continually with the word $K A \breve{S}+N I N I) A$, that is the "beer-loaf". Also the name in Sumerian for brewer, lì- $K A S^{\circ}+$ $N I N D A^{3}$, i. e., the "man of the beer-loaf", points to the close relation of the brewer and the baker. The texts acquaint us with a great variety of beers. We meet with the kas-gig, the "black beer", kas-si, the "red beer", kaš-š̆g, "fine-beer",

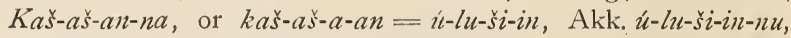
"spelt-beer", kaš "barley-beer", kurun-babbar, "fine white beer", kurun-gig, "fine black beer", kaš-sag, "prima beer", kaš-sag$a s^{\xi}-a$-an, "prima spelt-beer, $k a s ̌-20-q a$, "20 qa beer", $k a s ̌-30-q a$, "30 qa beer", kaš-40-qa, "40 qa beer", kas-as-a-an-mah= ulušinmah, Akk. ulušinmahluu, "fine spelt beer". In addition to these we also find a large number of so-called mixed beers, as for instance, $k a \grave{s}-a-s u d$, "beer mixed with water", also called $k a s$-bir, and the many beer names composed with the element

I) See Borchardt, in Aeg. Z., XXVIII, 189o, pp. $66 \mathrm{ff}$.

2) The first scholar, who explained these texts was Hrozny, Das Getreide im alten Babylonien, Wien, 1914.

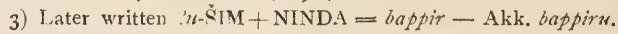


$i l-s a$, which according to Hrozný are all mixed beers. There

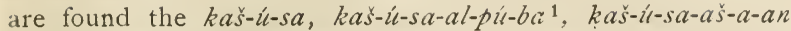
$=$ dida imgrigá $=\mathrm{Akk}$. dišiptahhu or alappanu, "a sweet mixed

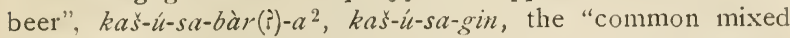

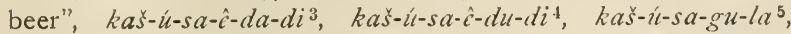

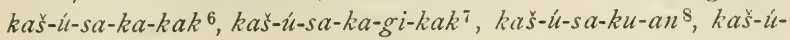

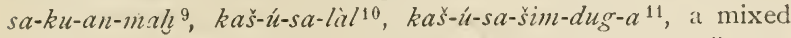
beer flavored with spices, $k a \grave{s}$-ú-sa-šg, "fine mixed beer", $k a s$ -

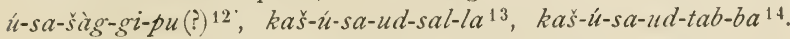
A special kind of beer was called kaš-nag-lugal15, "the royal beverage", as distinguished probably from the common beer called kaš-lu-gàl-la, "the beer of man" ${ }^{16}$. The saleable barley beer appears under the name $k a s^{2}-s_{e}-r i-a^{1 i}$. In BE, XIV, 161, 7 is found a beer called $k a s ̌-d u r-a n-k i$. See farther $K a s ̌-t i^{15}$, $k a s ̌-t i n$, a "fine beer", $k a s ̌--i n-5-?^{19}, k a s ̌-t i-r i-a^{20}, k a \check{s}$-ti-šar ${ }^{21}$, $k a s ̌-u m,(?)-\mathrm{ra}^{22}$ and $k a s^{2}-u m-r i-a^{23}$. The muititude of names, which the above list does not aim to exhaust, and which describe the different kinds of beer, show how many-sided and specialized was the industry of the Sumero-Akkadian breweries.

It must, however, be borne in mind that some of the beverages mentioned above, which are taken from so-called "lists", may refer to artificial wines just as well as to beer. So long as such names composed with $k a s^{y}$ are not found in texts in which the context can assist, the interpretation of

I) Ni. 10815; Dr. Chiera has kindly placed the lists of beers to my disposition.
2) Ni. 10820 .
3) Ni. 10872 .
4) Ni. 10872 .

5) Ni. $10816, \mathrm{Ni} .10873$.

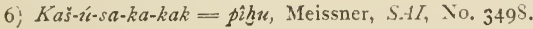

7) Ni. $\operatorname{LoS} \mathbf{3}$.

8) Ni. $10810, \mathrm{Ni}, 10811$; or read kaś-í-sa-aś(!)-an!

9) Ni. 10812 , or read $k a \dot{s}-\imath \iota-s a-a s ̌(!)-a n-m a h$ ?

10) Ni. 10815, a beer mixed with fruit-juices.

II) Ni. 10814. I2) Ni. 10819. I3 Ni, 10818.

14) Ni. 10817. 15$) \mathrm{Ni}, 10877 . \quad$ 16) Ni. I1 329.

17) Ni. II 324. I8) Ni. II 385.

19) Ni. I I 204; probably $q a$ is to be supplied.

20) Ni. I $386 . \quad 2$ I) Ni. 11080.

2 2) Ni. I1 326 ; probably identical with the following.

23) Ni. 11325 
some of these names must remain doubtful. This is due to

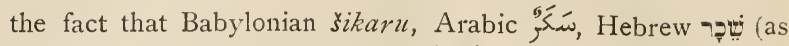
loanword in Egyptian ta-ki-ra script. Hierogl. 12) is one of the most ambiguous words in the Semitic languages. It may mean any intoxicating beverage prepared from grains, grapes, fresh or dried dates ${ }^{1}$, pomegranates, apples, honey etc. But even though some of the names mentioned may ultimately be recognized as words for artificial wines, there still must remain a great variety of beers, which is surprising.

The cheapest beer of the oldest time was seemingly the "black beer", kas-gig, which was prepared of barley only 2 . An exception is a text ${ }^{3}$ which enumerates an addition of spelt. A brewer furnishes 8 nigin $(=80 q a)$ of black beer. For its brewing he needs $18 q a$ of spelt, $18 q a$ of ninda-tam-maloaves, 24 qa of beer loaves and 36 qa of germinated grain!. The materials used for the "good black beer", kas-gig-dug-ga, differ little from the common "black beer". In order to brew

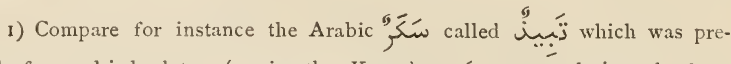
pared from dried dates (so in the Koran). سكر was also made from dried dates and from is growing profusely in Babylonia, and was probably used already in ancient times by the Babylonians, for the purpose of mixing it with their beverages. Whenever the cuscuta, $\mathbf{O}^{-}$, was not sufficiently cleansed from other herb;, on which it grows, the date-wine lost in quality according to Sar Shalom Gaon. For the occurence of the cuscuta in Babylonia see Pliny, XIII, 46. 2) de Genouillac, No. 34, Obv. IV, $5 \mathrm{ff}$.

3) de Genouillac, No. 45, Obv. II, I ff.; see Hrozný, Das Getreide im alten Babylonien, p. 154 .

4) The translation of kulug, by Hrozny, = buqlu as "malt", does not seem to me to be correct. Malt is out of place in the Babylonian method of brewing. Since the Babylonian method was similar to that of the Egyptian, where the process of boiling was unknown, it is difficult to understand what purpose malt could have served. We can get along very well with the

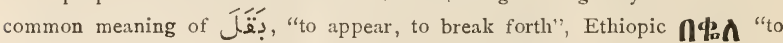
germinate". Bulug, then, seems to refer to a certain kind of grain, seemingly always barley (notice se-bulug besides bulug) that was dug into the ground and left there until it had commenced to germinate. It is still the custom in modern Egypt to use germinated grain for purposes of brewing. 
10 nigin of red beer ${ }^{1}$ there were necessary 96 beer-loaves, $72 q a$ of (hulled) spelt and $120 q a-s a g-g a ́ l$ of ground germinated grain. Hrozny ${ }^{2}$ has further shown that the Babylonian beers are valued according to the amount of spelt that was added to the barley and the barley products. The Babylonian "Prima beer", kas-kal, thus was composed often with somewhat more than $1 / 4$ of hulled spelt, or somewhat more than $2 / 5$ of husked spelt ${ }^{3}$. The "good black beer" was sometimes prepared from barley exclusively. So in Allotte de la Fuye, No. 169, Rev. I, $5 \mathrm{ff}$, and No. 170, I, $1 \mathrm{ff}$. In this case the more valuable barley products were used in larger quantity. The texts mention further a beer, which was of a syrupy thickness and was eaten. The name of this beer is written ideographically 领

We have followed so far the exposition of Hrozný, who gives a very detailed account of the composition of the Babylonian beers prepared with an addition of spelt in particular. Leaving out of consideration the surely erroneous idea that the Babylonians used malt with the preparations of their beers, Hrozny's investigations have given us valuable informations concerning the composition of the old Sumerian beers. The Sumerian beer recipes give us only knowledge of the materials of grain that were used by the Babylonian brewer, or the composition of different grains, with a statement of their respective amounts. They contain, however, no statements regarding the method of brewing itself. Since the texts, referring to brewing, always mention the beer loaves, it indicates that the method of brewing must have been very similar to the method employed by the Egyptians. For the making of beer loaves we may refer back to what has been stated above p. $78 \mathrm{ff}$. (The barley, or barley with the addition of spelt, was kneaded with the beer loaves in the same way as was customary with the Egyptians. We have, above, mentioned that amongst the vessels found in Rifeh there still remained in many a quantity of barley grain and of barley mash. In

I) See Allotte de lat Fuye, No, r68, Obv. I, i ff. and Hrozny่, i. c., p. 159.

2) Hrozny, l. c., p. I6r and p. 174 .

3) Hrozny, l. c., p. 16r. 4) Hrozny, l. c., p. 172. 
the tomb-painting at Deir el-Gebrawi we also noticed that the artist indicated the hidden contents of the brewing vat, showing the yellow grain in the white mass representing the beer loaves, which were trodden by the feet of a man who stands up to his knees in the rat. While with the ligyptians the process of treading the beer loaves and the grain, or the working and kneading of these substances with both hands was most characteristic as

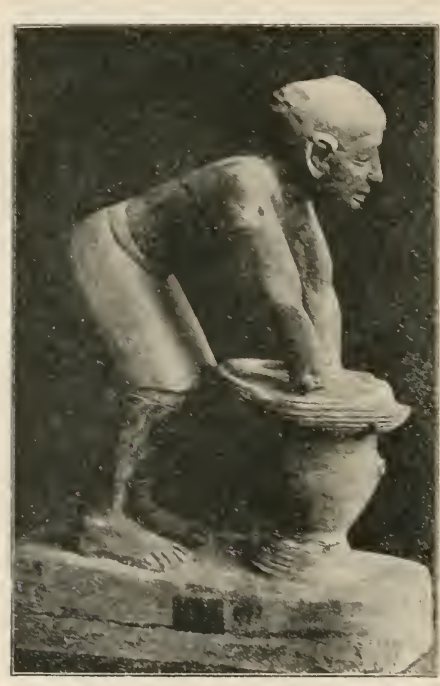

No. IS. An Egyptian brewer iatter Aeg. Zeitsihr. Bd. 35 ). the work of the brewer (see lllustration Nos. IS and 19), the Sumero-Akkadians considered the making of beer loaves as the activity most characteristic for the brewer. Thus, while the Egyptians called the brewer " $f t y$ ' and represented him ideographically by the sign Sumero-Akkadians called the brewer lì-KA $\dot{\mathbf{S}}+$ NINDA, or hapfir, i. e., "the man of the beer loaf". It is thus probable that the verb "Iahimu", which is used to indicate a certain activity of the brewer, contains plainly and simply the word for brewing, originally probably "to make loaves".

Lahimu is of course connected with the Hebrew word =nis "bread", and indicates that the activity which to the minds of the Egyptians was most characteristic of the brewer, was also so considered by the Sumero-Akkadians, and probably means also the same as the Egrptian ' $f t$, "to wring, to knead, to press, to stir". The industry of brewing beer thus was alike both in Egypt and in Babylonia. Both countries supplement in their literary and pictorial remains our knowletge of the making of beer 
in the Ancient Orient. Egypt contributed to our knowledge of the methods used in brewing beer, and Babylonia gave us the earliest beer recipes. It may finally be remarked that whenever Babylonian texts speak of honey ${ }^{1}$ in connection with beverages, this refers not to beehoney, but to a syrup prepared from fruit-juices, which was thickened with sikaru, "beer". Also the Hebrews prepared this beverage, which

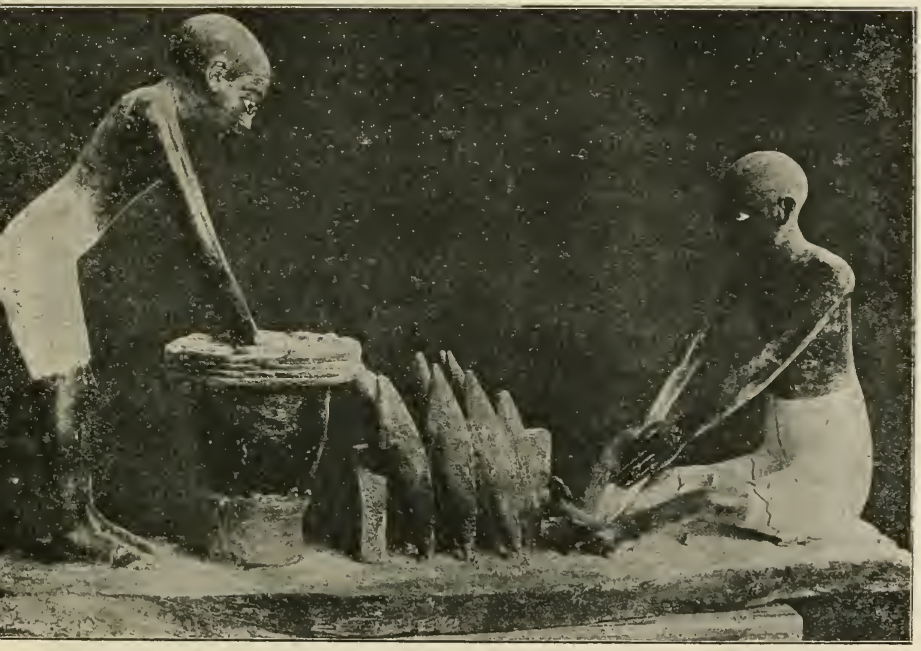

Yo. 19. Brewer and bottle washer (after Aeg. Zeitschr. Bd. 35).

according to Lev. 2, 11 was excluded for ceremonial purposes 2 . Strassmaier; Inschriften i'on Darius I, No. 168, line 2, mentioning "one year old beer", evident that the Babylonians knew well to preserve the quality of the beer for a longer period.

1) Murd, iing-ga, tablu.

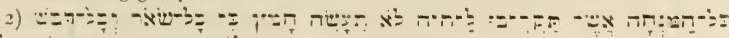

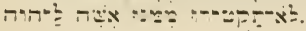


A contract of the time of Xerxes narrates the hiring of a certain brewer named Nabû-ušallim for the purpose of preparing mixed beer for the repast of the god Nabû. It reads ${ }^{1}$ : 300 clay jars ${ }^{2}$ of beer for the repast of the god Nabû, belonging to Rimût-Bêl, the son of Iddina-Nabû, the descendant of Ilu(?)-abušu(?), he has given for preparing unto Nabûušallim, the son of Nabû-aplu-iddin, the descendant of Lâkuppuru. For the keg Rîmût-Bêl shall give to Nabû-ušallim $78 q a$ of barley and $6 q a$ of ..... cassia-spice. Then he shall mix the kegs to the amount of 300 , execute (it) and give (the kegs) for the cellar(?) of Rîmût-Bêl and of Marduk-balațsuiqbi, beginning with the month of Kislev of the 36 th year $^{3}$ according to his document. He shall stand good(?) for(?) the correct delivery of good mixed beer before the cellars(?) of Rîmût-Bêl and of Marduk-balațsu-iqbi. He shall stand security for it that the offering of the repast (of the god Nabû) suffers no delay and for ......... Nabû-ušallim shall give nine kegs ..... unto Rîmût-Bêl. Therefrom (!) Nabû-ušallim has received from the hand of Rîmût-Bêl So gur of barley and the remainder of the barley in Barsip(?) ....... RimutBêl shall give to Nabû-ušallim. The cassiaspice(?) Rîmût-Bêl shall give to Nabû-ušallim in . ..... 1 gur . . . . Rîmût-Bêl shall make with Nabû-ušallim. In the house of Rîmût-Bêl, which is closed up, Nabû-ušallim shall dwell. He shall take care of the work of repair of the walling. For three years he shall cover(?) the roof. The work of tiles, cane and beams, as much as Nabû-ušallim shall make in the house of Rîmût-Bêl, which is closed up, Nabû-ušallin shall reckon up to the charges of Rîmût-Bêl. For ....... and housefurniture, which Rìmût-Bêl shall entrust to Nabû-ušallim in the closed-up house, Nabû-ušallim is responsible. Nine ...... .jars, 18 clay-kegs ........... two bukannu, one mixingmachine of cane, one ..... of cane, ...... one ....

I) See VS, VI, I82.

2) Tuns, barrels and casks, which were made of wooden staves and held together with hoops are an invention of the Gauls. See Pliny, AIV, 132 $^{2}$ circa Alpes vinum ligneis vasis condunt tectis circulisque cingunt.

3) That is the 36 th year of Darius I.; which was the accession year of Xerxes. 
...... belonging to Rîmût-Bêl are entrusted to the disposition of Nabû-ušallim"1. The brewer, according to the document, is hired for the period of three years in order to prepare mixed beer, for which he receives certain quantities of barley and cassia-spices. In return for his labor he is given a house with its furnishings and the brewing outfit, for the good keeping of which he is held responsible.

The Old Testament mentions the šekhâr (Deut. 29, 6; Judg. 13, 4 ff.; I. Sam. 1, 15; Lev. 10, 9; Is. 28, 7 etc.). On account of the too general meaning "intoxicating drink" it is impossible to determine in each instance whether a certain kind of artificial wine or beer is intended. Nor does Jerome know what kind of beverage it was ${ }^{2}$. From passages such as Lev. 2, 11 it becomes, however, evident that the word šêkhâr was also applied to the beer. For the šêkhâr prepared from grain, see Pesach. III, 1. The brewery was known in Rabbinic times by the name "place of the brewing vat",

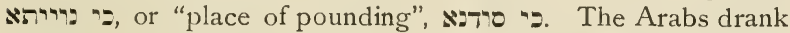
a certain beer called fokk $a^{3}$. Simon Seth ${ }^{4}$ characterized it in the same way as the zythos by the earlier writers. He states that the fokka is a good beverage for those who have a very. warm constitution, particularly in the stomach and the abdomen, and for those persons who suffer considerably from thirst on account of excessive heat. The fokka is particularly good on hot days, if it is free from any spices. It drives away thirst, stimulates appetite, is laxative, and causes frequent urination. It is, however, harmful to a watery stomach and persons with cold temperament. The Arabian beer was drunk by the Byzantines under the name poukä s. According to Temimy a variety of beers were called by the name fokka. This writer gives the following account of its property and its ingredients: „Different kinds of beer are made. There is one which is pre-

I) Follow the names of witnesses.

2) Ep. ad Nepotian, ed. Vallarsi I, 266: Sirera hebraeo sermone omnis potio, quae inebriare potest, sive illa quae frumento conficitur sive pomorum succo, aut quum favi decoquuntur in dulcem et barbaram potionem, aut palmarum fructus exprimuntur in liquorem, coctisque frugibus aqua pinguior coloratur.

3) See de Sacy, Chrestomathie arabe, II, 437.

4) p. I I $S$ ff. 
pared from germinated, dried (and) ground barley-flour, being fermented with mint, rue, dracunculus hortensis, leaves of the lemon-tree and pepper. It is warm, dry, exceedingly putrid (and) harmful to the stomach. It produces flatulence and rumbling and injures the brain-nerves, because it fills the brain with thick, warm vapors, which pass off with painful difficulty: And often, on account of its bitterness and its pudridity, it causes diarrhoea; and often it causes diseases of the bladder and heartburn to those who make a habitual use of it. As for (the beer) prepared with bread of the best grade wheat flour, well prepared, of parsley, and of fine germinated wheat, or germinated barley flour - it is less dangerous than the first kind. It is more suitable for choleric persons. But those who are of a rather moderate temperament, and who desire to prevent its (causing) flatulence, winds and rumbling, and to render it moderately warm, and to strengthen the stomach, put into it some aromatic plants, which benefit and strengthen the stomach on account of their aromatic nature, and their absorption of its moisture, as e. g., hyacintl, mastix, cinnamon, long pepper, musk, some cardamom and nutmeg and clove. Of the powder thus made from these spices let one mithkal (two drachms in weight) serve for each twenty jars of beer (the jars being of the kind called?) ${ }^{1}$. If it is desired to render it agreeable of taste, there must be put into each jar a heart of dracunculus hortensis, and two leaves [of the heart] of a lemon-tree, with a little rue and mint. They make also a more simple kind of beer, with water, bread of best grade wheat flour, well prepared, having been filtered, and an infusion of musk and mastix only, with a heart of mint in each jar, or a heart of dracunculus

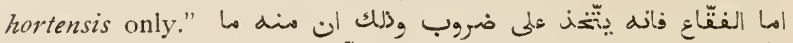

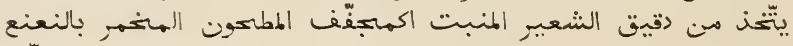

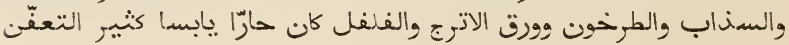

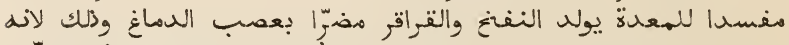

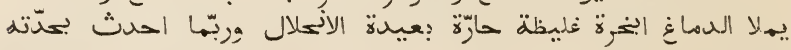

I) De Sacy reads: : الضار. We should evidently expect here the name of a vessel with a specification of its size. 


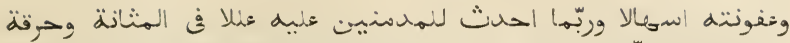

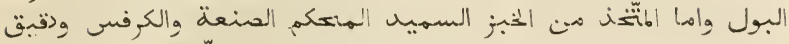

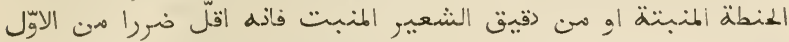

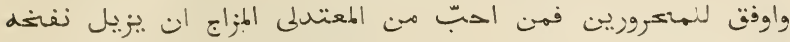

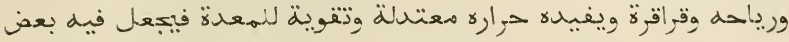

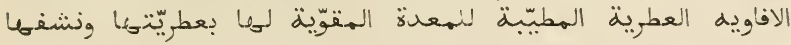

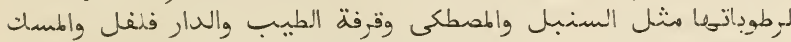

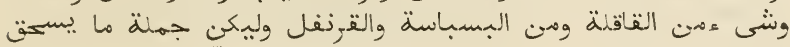

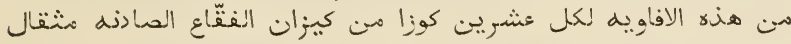

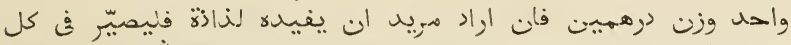

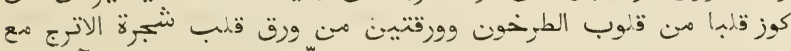

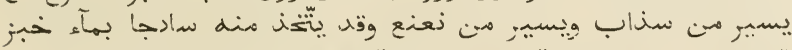

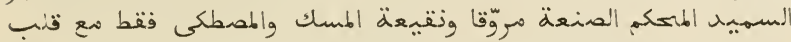
نئ Another kind of beer was called mizr, misar, jo which the Kâmûs explains as iئi "wine of durra and barley". De Sacy (Chrest. Arab. I, p. 150, 151) identified minr with the Greek koúput, a stronger kind of beer than the รư গos. This identification, however, is doubtful. According to Ibn Baitar II, 513 it was prepared of wheat, durra and barley and was the national drink of Egypt long after it had embraced Islàm. The misrbeer was subject to a government tax (Makrizy, Chitat I. 105). Bokhary mentions the use of this beer also in South-Arabia.

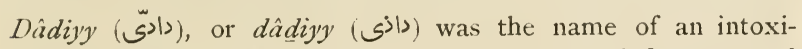
cating beverage, which was probably prepared from a seed of the same name. This seed tasted bitter, and resembled the barley, being, however, somewhat thinner and longer (see Reinaud, Relations des voyages faits par les Arabes et les Persans, Paris 18+5, 55). According to Gawaliky 108 the Abyssinian beer, called ghobairâ, or sokorkal (sokorka'), which was introduced into Arabia at a very early time, was especially prohibited to be drunk, since Mohammed had placed it in the same class as wine. The sawiq, (سويتن), a particularly favored drink, seems to have been quite harmless. It was a barley-water,. which was imbibed from the vessel by means of straws, and was generally drunk by sick persons. 
When Niebuhr visited Arabia, he found the Arabs drinking a beer that was white and thick, being prepared from flour ${ }^{1}$.

In the subterranean dwellings of the North Armenians Xenophon ${ }^{2}$ saw jars filled with barley beer. Barley was mixed with it up to the brim. The Armenian barley beer was very strong if it was not diluted with water. One who became accustomed to the taste of this beer found it very agreeable. Old Cappadocian documents ${ }^{3}$ show that during the third millenium B. C. beer was brewed in Asia Minor by the same methods used in Babylonia.

I) Niebuhr, p. 57 .

2) Anabasis IV , 5, 26 they (the peasants of the Armenian mountains)

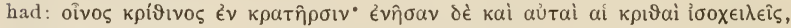

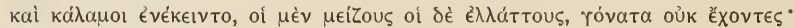

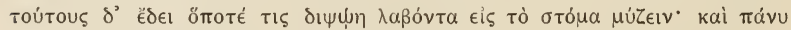

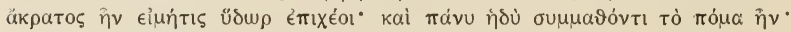

3) Golenischeff, Vingt-quatre tablettes cappadociennes. 


\section{Chapter Four}

\section{Wine and Beer in the Daily Life and Religion of the Ancient Orientals}

In Egypt, as well as in Babylonia and Assyria, we find only one view regarding intoxicants. This view is of a favorable character, as far as the national conscience of these peoples is concerned. It was impossible during the early stages of the national development of these peoples that any considerable group should rise up in protest against the excessive use of beer or wine. Intoxication was not yet considered as constituting a moral offence against the drinker's own self and against society at large. It was, on the whole, rather considered in the light of a harmless pleasure in which one might indulge. The moral sense was still too undeveloped to put a different construction on excessive drinking. In Pap. Anast. IV, 3, 7 it is stated that the mouth of a perfectly happy man is filled with wine, beer, etc., 18 $\triangle 8$. The same text refers to the hilarity that it caused by wine, 40 L But there were always individuals who took a different viewpoint, and as ages passed, the moral sense of wider groups of people reached a stage where it found intoxication unbecoming to the dignity of a man. So at the time of Athenaeus the Egyptians were described by him as temperate in banquets of every kind and that they used only so much wine as was necessary to gladden the heart. The statement

Lutz, Viticulture and Brewing. 
of Athenaeus reflects, however, only one group of Egyptians. Herodotus ${ }^{1}$ presents us with the second group. The drinking

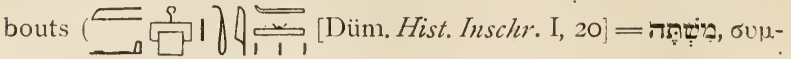
róбtov) generally started after a meal. Then a wooden image of a dead person was carried about and to each guest was given the admonition: "Behold this one, drink and be happy, for after thy death thou wilt be like this onel" That the second and probably far the larger group heeded this admonition well is richly illustrated in the tomb-paintings of Beni-Hasan. They show us that beer and wine were drunk

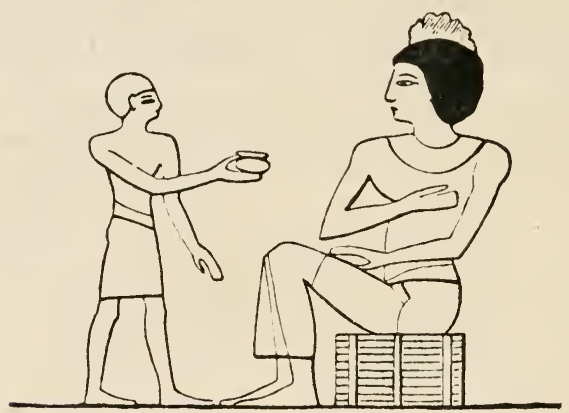

No. 20. Slave offering wine cup to a lady (after Wilkinson).

by the Egyptians often to excess and that the women of the upper classes were also not free from this habit. Illustration No. 20 shows a slave offering wine to a lady. Two slaves carry their totally drunk master, one at the foot, the other at the head. They are followed by three slaves who have lifted their master on their heads and carry him away like a stiff pole (see Illustrations No.21). The first slave holds with his hand the head of the master. On a wall-painting at Thebes we behold an even more unesthetic picture. Ladies, overcome by the use of too much wine, pay a painful and ugly sacrifice to Dionysos (see Illustration Nos. 22 and 23). The lotus-flower, bent over the arm of a drunken lady indicates her condition, for this flower

1) Herod. II, 7 s. 
Wine and Beer in the Daily Life and Religion of the Ancient Orientals.

determines also the concept of intoxication ${ }^{1}$. These ladies are held by their female servants. For an Egyptian banquet scene

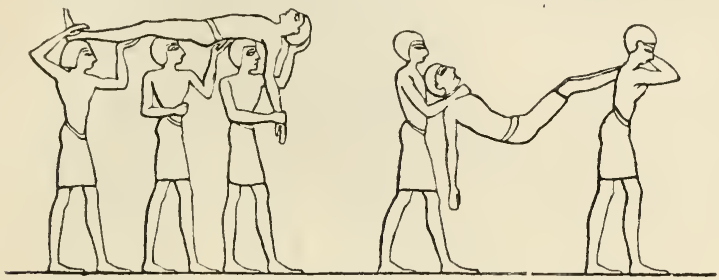

No. 2I. Scene after the close of a banquet (after Wilkinson).
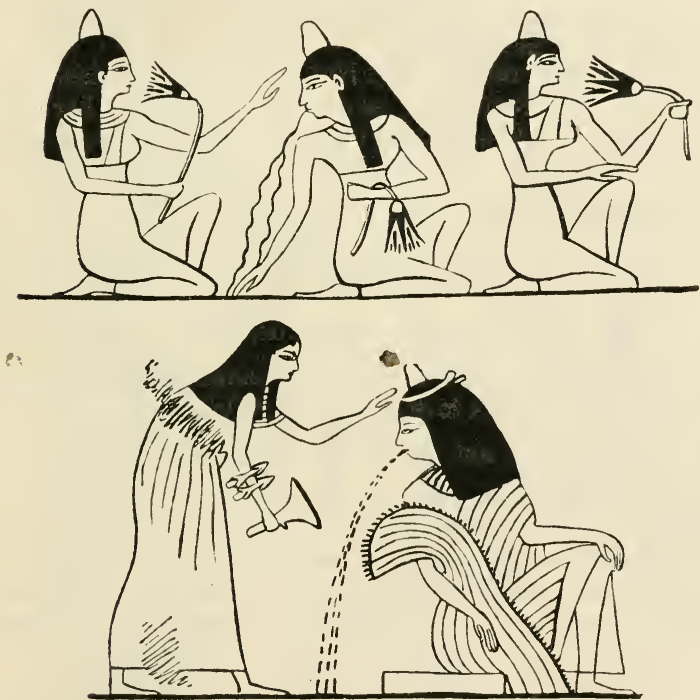

Nos. 22 and 23. From a Theban tomb (after Wilkinson).

1) So in Demotic 04 . The lotus-flower, in a more general way, serves as determinative of joy, f. i., in the vert) "to rejoice, to be in an 
see Illustration No. 24. In the banquet scene of the tomb of Paheri we are enabled to become quasi listeners to the form and tone of conversations that prevailed at these banquets. A servant had offered to Amen-sat, one of the daughters of Kem, a drinking-bowl. The lady was of another type than her sisters of Thebes. She refused the proffered drink.' The servant, forgetful of his position while the drinking-bout progresses says jokingly: "(It is) for thee ${ }^{1}$, drink unto drunkenness (and) celebrate! O listen to what thy companion is saying,

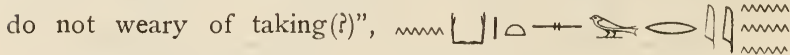

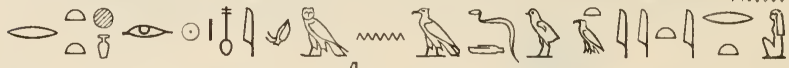

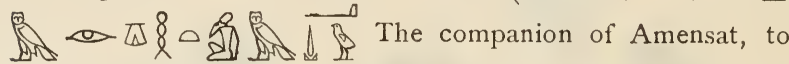
which the servant refers, called Nub-mehy, is her distant cousin. She is of a different type, as we can judge from her words, with which she addresses the porter: "Give me eighteen cups of wine", she calls out unto him, "dont you see ${ }^{2}$ I want to get drunk! My insides are as dry as straw!", \&

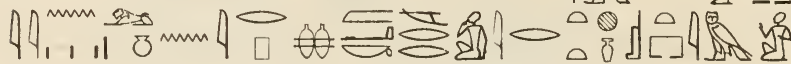
mи $\Longleftrightarrow\{$ ? of refusal with her hand. It is the nurse Sensenbet, whom another servant invites to drink, saying: "Drink! Do not refuse(?).

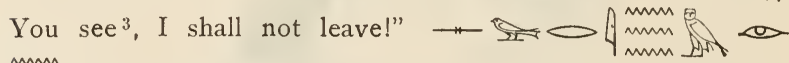

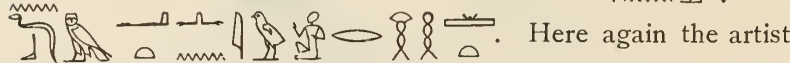
has grouped Sensenbet with a lady, the nurse Tupu, who calls upon her to drink and not. by her refusal, spoil the entertainment. She says: "Drink! do not spoil the entertainment.

exalted mood", $\infty$ D DKI, II 2; DKI, 105.

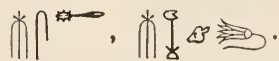

r) Lit. "(It is) for thy $k a$ ".

2) Lit. "Behold", which in English, is too formal.

3) Lit. "Behold". 


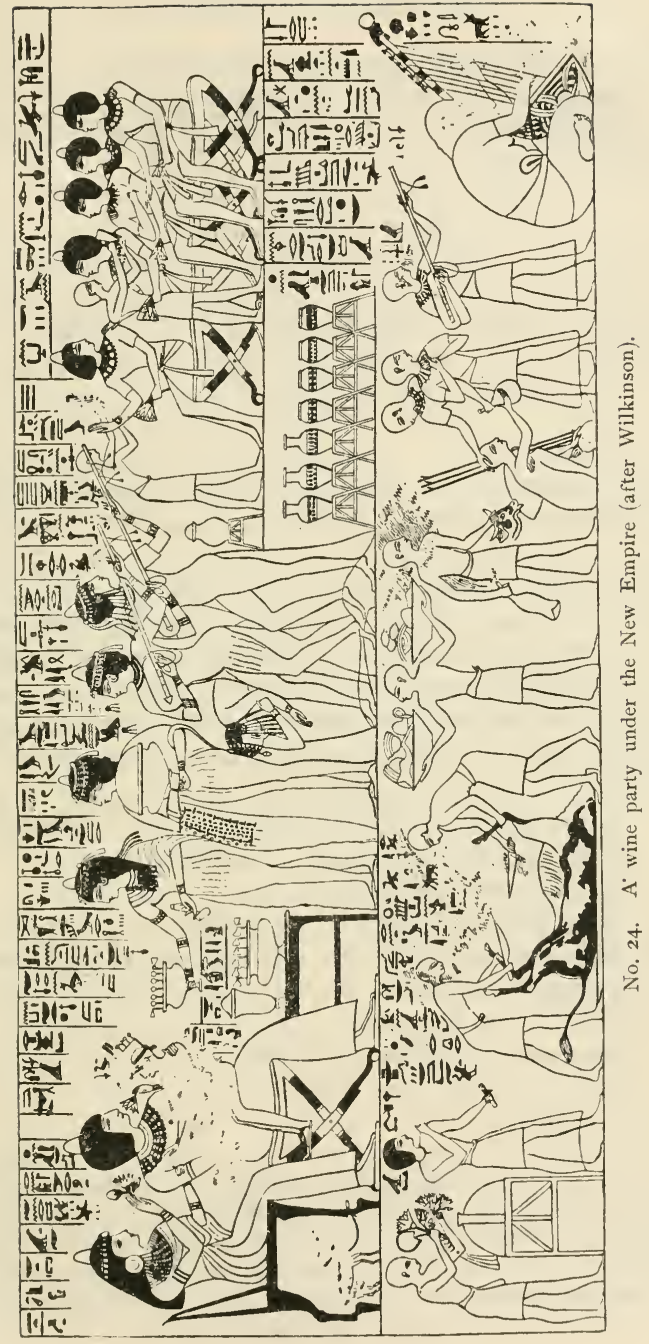


Let the cup reach me. You know ${ }^{1}$ it is due unto the ha to

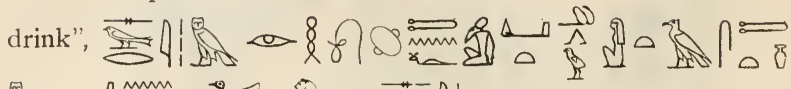

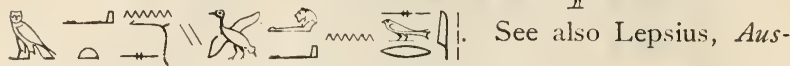
wahl, 16, line 16: "Do not cease to drink, to eat, to intoxicate thyself, to make love, (and) to celebrate good days",

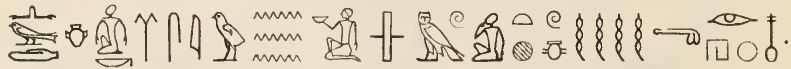
The Egyptian toast seems to have consisted in the address: $k$ 'i-k, i, e., "to thy double", or rather $k$ ' $i-h r-k$ ' $i, L$ word is preserved in the name of the month Koiahk. кІАгк, ХоıлгК, ХоІак; Хolók and in the name of the vessel $k u-i-$ ih-ku (Winckler, Amarnataf. No. 294; see OLZ, 1899, Vol. II, 105).

A few songs, which seem to have been most popular at banquets, have come down to us. They contain exhortations similar to the one Herodotus had taken down. The Egyptians are advised therein to enjoy life to the utmost, and to use every day for mirthmaking until the day shall come to depart for the land whence none returns. Pap. Harris 500, $6,10-7,3^{2}$ :

"Place aromatics on thy head!

The garment on thyself (let be) of byssus,

Dipped into the precious (and) genuine things of the gods!

Surpass (even) thy life of pleasure (shown hitherto)! Let $[$ not $]$ thy heart get weary!

Perform thy affairs on earth

I) Lit. "Behold".

2) See Goodwin, TSBA, III, ${ }_{3} 87$; Maspero, Fourn. Asiat., I880, 404 also Etud. Egypt. I, 164; Erman, Aeg. 516, Griffith, World's Best Lit. 5316 and Müller, Liebespoesie, pp. 29 and 30 . See also Müller, ibid. pp. $3 \mathrm{I}-33$ and the text published in Reinisch, Aegypt. Chrestomathie I, 20, in which the deceased lady Ta-imhotep, the wife of the high-priest of Memphis, implores her husband to enjoy this present life to the utmost, since the underworld is a land of dense darkness and a dreary place for the dead. 
Wine and Beer in the Daily Life and Religion of the Ancient Orientals. 103

according to the bidding of thy heart!

That day of lamentation will come to thee,

(in which) he of a paralyzed heart will not (be able

Weeping will not compel

to) hear their mournings.

the heart of a man (to beat) in the tomb.

Moral(?): Celebrate the joyous day!

Do not rest in it!

Behold! It was not granted,

to take along one's possession.

Behold! There is none, who has gone hence

and has returned again.

At banquets the harp-player was seldom missing. We possess an interesting, though very difficult text ${ }^{1}$, which describes the manner of life this minstrel lived and particularly his struggle for existence. $\mathrm{He}$ is in want and privation. He knows only one song, of which the theme is "I am hungry and thirsty". When he goes to the banquets of the rich, he first eats and drinks. But moderation in eating and drinking is an unknown virtue to him. "He drinks for two, he eats for three, he satiates himself for five". When he is called upon to play his harp and accompany his instrument with his song, he is so drunk that he is unable to perform and the guests chase him away from the banquet-hall.

"He has doctrine and he has not. ( $\mathrm{He}$ is) like one who can not speak, although (being) intelligent, and who does not know to answer in a satisfactory way. ( $\mathrm{He}$ is) like a fool who has digested a book, in which is contained every teaching, and (yet) he is able to sing only one song, since he was born: "I am hungry, I wish to drink. Is there nothing to eat(?)". . . . . . when before him he sees meat. He searches after the blood more than the fly, (more than) the vulture that has decried the massacre.

He will be able to pass four days awake, to look for provisions, being fully dressed they call unto him "There is

1) Vienna Domotic papyrus No. $3^{1}$. This text was first translated by Revillout in the Revue igypt. After this first endeavor, Krall published partly a new translation. See now Revue ligypl., 1919. 
meat in such and such a bad placel", and he is already there with the harp. He has no ........ (it is) the throat(?) of the man, who destroys his own self. As soon as he has found wine (and) meat before him he goes there without being invited. He converses with the guests: "I can not sing, I am hungry. I can not bring the harp in order to chant (it), without having drunk, (and) eaten from the jar ........... And he uses wine for two, meat for three, food for five together. The harp presses (against) his heart; it is like a heavy load. He causes them to call to him three times for a song. He is accustomed to carry the harp in order to inebriate himself, in order to exhibit every kind of vice in him. He play's (on) the harp in entire discord ........ "Serve food". He turns it to his side. He responds to recite the ... $\ldots . \ldots$ He is accustomed to exaggerate his art. (For) his mouth is his strength, (and) his words do not bear witness to his art. It differs his voice, it differs the harp; his bat behavior, his art speak against him, against the order to sing. "Shame with thy splendor!" They are unaccustomed ...... until ........ the pupil of his eye. They will not receive him at another place because of his many vices. Once satiated he leaves the harp, he flees, he departs. I He causes the hour to pass to show(?) his face."

Krall was the first scholar who recognized ${ }^{1}$ that this text belongs to the same class of literature, which depicts in a satirico-humorous way the life and doings of men of different professions and crafts, as contained in Pap. Anastasi III, 3, 94, 4; V, 8, 1-9, 1; Anast. III, 5, 5-6, 2; IV, 9, 4-10, 1; Anast. V, 15, 6-17, 3 and Pap. Sallier I, 6, 1-9; Pap. Sallier II, 4, 6- 8 . In a company of high-living guests the harp-player fell an easy prey to a debauched life. The text was probably written as a warning to those who desired to choose the tempting life of a musician and minstrel as their life's work. The harpplayer is no uneducited person, "he has doctrine", but is of a mind that seeks, since his early childhood, his highest

1) See Rec. de tran'. V, Pl. $76-78$. 
Wine and Beer in the Daily Life and Religion of the Ancient Orientals. 105

ideals in good and plenty of food and drinks, until he becomes so depraved that his presence is offensive even in those circles, which otherwise are all but Puritan themselves. The intoxicated husband, who returns home from the banquet, does not meet an enfuriated wife who showers him with reproaches anc moral lectures. She removes the wreaths, the banquet-adornment, when he has retired (Pap. Harris, 500, 7 , 11,12). The young Egyptian student, it appears from a letter written by a teacher to his pupil ${ }^{1}$, was prone to forget his studies and frequent the taverns of the city in order to get drunk on home-made and imported wines. The teacher writes:

"I am told that thou forsakest books (and) dost abandon thyself to pleasure. Thou dost wander from tavern to tavern.

Every evening the smell of beer, the smell of beer frightens men away (from thee).

It corrupts thy soul, (and) thou art like a broken oar.

Thou canst guide to neither side.

Thou art like a temple without a god, (like) a house without bread.

Thou art detected as thou climbest up the walls, and breakest the plank.

The people flee from thee, and thou dost strike and wound them.

$\mathrm{O}$, that thou wouldst comprehend that wine is an abomination

and that thou wouldst abjure the pomegranate-drink; that thou wouldst not set thy heart on fig-wine, and that thou wouldst forget the carob-wine.

The Egyptian public beer- and wineshops $\frac{0}{6-8} C_{0}$,

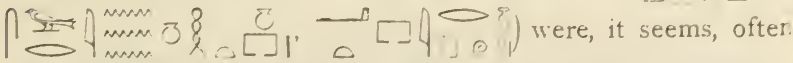
also dens of prostitution. We see on one monument girls in the company of an intoxicated man. The Egyptian demimondaines embrace him in this condition in which he

1) Pap. Anast. IV, I , 8 ff.; cf. also Sallier, I, 9.9 ff. 
was an easy mark to their lures. The girls have placed a wreath around his neck and have anointed him with oil. Wild scenes and disorder may often have ended the drinking bouts, as we read in a love-song: "The banquet is disordered by drunkenness" 1 . The keepers of public taverns stood very low in the estimation of the better class of their fellow-citizens. We gain this information from a satirical remark in which a taverner figures as criterion for the moral lepravity of a certain scribe Roye, the cattle-counter Kasa and an official of the treasury called Amen-wah-se. It says ${ }^{2}$ : "Well then, I describe(†) unto thee Nakht, him of the wineshop; he is ten-times better for thee than these",
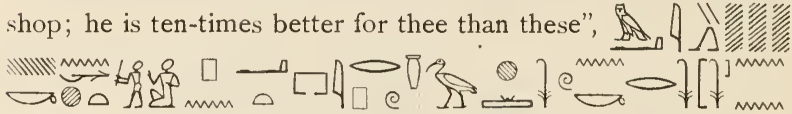

$\cap-$. At social gatherings the participants were invited to drink heartily. In the tomb of Ahmes at el-Kab we read: "drinking unto intoxication and celebrating a festive day", swry $r$ thl iry lirw nfr. A servant carries to Amenemheb ${ }^{3}$ and his wife a beverage 0 , "good intoxicating drink". Holidays were always especially days of great drinking bouts. Thus we read 4: "The soldiers of his Majesty were drunk of wine and anointed with oil each day as on a holiday in Egypt"

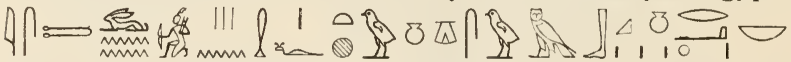
Q 4011 An 8 व wine and beer must have been enormous ${ }^{5}$. It was brought to kings, warriors and priests by right of state in specific quantities. Every warrior, for instance, if we can trust the statement of Herodotus ${ }^{6}$, of the royal body-guard, which consisted of 2000 men received four measures of wine.

I) Turin love-songs, Maspero, Étud. Égypt., I, $22 \mathrm{~S}$.

2) Pap. Anast. I, 9, 4 ff. See also Aeg. Z., 44, pp. 124 and I.25.

3) Sethe, Urkunden IV, pp. 9 I 6 and 9I7.

4) Sethe, Urkunden IV, p. 688.

5) Ramses III. says: "I gave every day wine and must, in order to equip with abundance the land of On" (Pap. Harris I, 27,8).

6) Herod. II, I 68. 
Every priest, who performed service at the temple, received one measure. The Egyptian calender contained a "day of

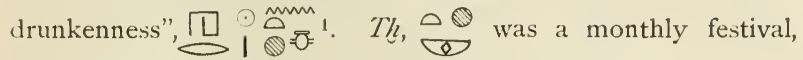
which was celebrated on the twentieth day of the month of Thot, Coptic $\Theta 00 \gamma$ r, $\Theta \omega 0 \gamma$, Greek $\Theta \omega \vartheta$, $\Theta \omega$ viv. The name of the first month of the year, Thot was probably originally called thy, $\backslash 1$, which referred to the "vintage-festival", or, "vine-festival", which originally inaugurated the NewYear of the Egyptians. The old Canaanites similarly, commenced the New Year with the vintage, or rather after the wine-harvest. It is possible that the origin of the Purim festival goes back to the old Canaanitish vintage-festival (Purim etymologically connected with pîra, "the wine-press"). Herodotus II, 59 mentions that at the tekhu-celebration of the bacchanal Bubastis (Bestis)-festival, there was more wine drunk on one day than throughout the entire year. These festivals, celebrated in honor of the catgoddess, were of proverbial gaity and men, women and children came from all parts of Egypt to take part in them. "The gods of heaven rejoiced, the ancestors diverted themselves, those who were present became drunk with wine, their heads were crowned with flowers, the inhabitants ran merrily to and fro, their heads streaming with perfume, in honor of the goddess; the children skipped sportively about from sunrise to sunset" (Dümichen, Bauurkunden, p. 21). In the inscription of Tehutineht, son of Nehera, in the quarry of Het-Nub, the dead is praised as (10): "loved by alls his town(s-folk), women as well as men, not conspiring evil, (11) great of beer (

Although the Egyptian monuments make it clear that the Egyptians were heavy beer- and wine-drinkers, and that from their early youth, according to a passage ${ }^{2}$, which states that a good mother is accustomed to bring to her 'son, who attends school, three loaves of bread and two jars of beer daily, yet there were at all times voices raised against

1) Cf. Düm. Resultate, 51, 25: $m$ hrre tpy $n$ th.

2) Pap. Ani, 20, 20; cf. Yap. Sall. II, 10, 6. 
drunkenness. Sentences such as "A cup of water satisfies the thirst" 1 , or, "A short minute overpowers the heart" ${ }^{2}$, or, "Do not set thy heart on fig-wine" ", show this conclusively. The scribe Ani indulges in the following warning: "Do not pass (thy time) in the beer-house and thou shalt not speak evil about thy neighbor even in intoxication. Then (if) thou fallest to the ground, and thou breakest the limbs, none reacheth out the hand to help thee. Behold, thy companions! They drink and say: Go home, thou, who hast drunk enough!". It is pretty certain that moderation in drinking was recommended to the kings more than to any other class, in view of the dietetic and other laws by which the priests have regulated and assured the life of the king ${ }^{4}$.

Many references to drinking are found in the Egyptian love poetry. The lover is even satisfied to go without his accustomed beer, as long as he enjoys the pleasant company of his sweetheart ${ }^{5}$. A beautiful lovesong, with a reference to the sweetheart making her lover drunk with love as well as beer or wine, is the following 6 :

"The little sycomore

which she has planted with her hand,

commences to speak,

and its (words are as) drops of honey.

It is charming, its foliage is beautiful,

more green than the (papyrus).

It is laden with fruits

redder than ruby.

Its leaves are like malachite,

their color is (transparent) like the glass;

its stem is like the color of the (yellow) nešmet-stone,

I) Pap. Prisse, I, 5; cf. also I, 8 etc.

2) Pap. Prisse, I, 4.

3) See also Pap. Anast. I, ro, $3 \mathrm{ff}$.

4) Diod. I. Jo. Clemens Alexandr. Slromata, YI, p. 633 mentions tòv

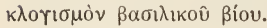

5) See Müller, W. Max, Liebespoesie.

6) Maspero, Turin pap. 79-83. Étud. Égypt., I, p. 217 ff. and Erman, A., Ägypten und ägyptisches Leben im Altertum, Tübingen, r885, pp. 272 and 273, W. M. Müller, Liebespoesie, pp. 39 and 40. 
Wine and Beer in the Daily Life and Religion of the Ancient Orientals. 109

round(:) like the Besbes(-tree),

its shade cooleth.

It sends its letter through a small girl, the daughter of the chief-gardener.

It causes her to hasten to the much-beloved:

"Come and tarry amongst the young people.

The meadow, full of bushes, celebrates(?) its day.

The arbor and the tent are to thy disposal.

Thy village-chiefs rejoice,

(and) the young folks, who behold thee!

They send thy slaves ahead of thee

The servants, who belong to thee

furnished with their tools,

are drinking, while hastening to thee,

before they have (started drinking),

(when they) hear their comrades,

coming with their utensils.

They bring beer of every (kind),

all kinds of mixed bread,

many flowers from yesterday and to-day,

and all kinds of refreshing fruits.

Come, celebrate this day,

and to-morrow and the day after to-morrow three days

sitting in my shade.

Her companion sitteth to her right side,

(and) she maketh him drunk,

she obeying that which he sayeth

(when) the drinking-bout becomes disordered by drunkenness

(and) she is left alone with her brother

unwrapping herself below me,

the sister, on her promenade.

I am of a silent mind,

and do not say anything, that I see,

and I do not tell ..............

In the records of the so-called Harem conspiracy we read that certain persons had forsaken the king's instruction and that the women had gone to these men, one an infantryofficer, the second a captain of police, the third a butler, the 
fourth a scribe of the archives, and the fifth a standard-bearer of the infantry. Both men and women had gotten drunk, or as the phrase expresses it, they had "made a beershop", '.t-hk.t. The butler evaded court-proceedings by taking his own life. The standard bearer Hor was acquitted. Tefnahte, in his message of submission expressly states "I have not sat in the beershop" !.

Beer has found a place in Egyptian mythology. Once upon a time in primeval days Rêt reigned as king over men and gods. But he grew old, his bones were silver, his limbs gold and his hair was genuine lapis-lazuli. He had become old and stiff. Mankind became aware of this and had put it in their minds to blaspheme the old god. But their thoughts became known to $\mathrm{Re}^{\mathrm{c}}$ and he caused the gods to assemble before him in order to inflict a punishment upon mankind. This he did so secretly that the people were kept completely ignorant of his plans. Rêt sent his eye, which descended as the goddess Hathor. She killed the people, who had started to take refuge, stream-upward, into the mountains. The rage of Hathor was so furious that it became too much for Rêt. But Hathor's fury knew no bounds. She did not want to stop the slaughter, until the last man was destroyed. She waded, against the will of the sungod, for a number of nights in the human blood, until, finally, Rêt conceived of a trickery. He caused immense quantities of beer, which was red-colored, in order to look like the blood of men, to be poured over the fields ${ }^{2}$. The beer attracted the goddess. It tasted good to her and she returned home in an intoxicated condition, not recognizing the people. Thus, some people were saved, who had taken their refuge in the desert. The beer, according to this myth was prepared of barley and dada-fruit, i. e., the mandrake-fruit from Ethiopia. "Hasten to the island of Elephantine, and bring me much dada-fruit", is the order given by $\mathrm{Re}^{\mathrm{r}}$ to his messengers. When they had brought it, $\mathrm{Re}^{\hat{c}}$

I) Pianhi Stele, I, $133 \mathrm{ff}$.

2) "On that day Rêt [stood up] in the best part(?) of the night for causing this sleeping draught to be poured out, and the fields were flooded four spans high by [that] liquid through the power of the majesty of this god". 
gave it to the goddess Sektet ${ }^{1}$ of Heliopolis, in order to grind it. The dada-fruit was added to the barley which was crushed by the slaves, and the whole was mixed together with the blood of men, making thus 7000 jugs of beer Another version has it that wine was made, instead of beer, out of "the blood of those who formerly fought against the gods" 2. Plutarch in this connection asserts that before the time of Psammetichus, the kings had abstained from wine, and had even not allowed themselves to offer it up as sacrifice, since wine was held to be the blood of the one-time enemies of the gods. The one version gives us the origin of the beer, the other that of the wine. For it states that when these enemies of the gods were killed and their blood mingled with the earth, the vinestalk was created. The story of the first version winds up with the statement: "Thus originated the girls in the Pleasent City. Rêc said to that goddess: 'Make sleeping-draughts for her at the time of the New Year festival! Their number (shall be) according to(?) that of my (temple) slave-girls.' Thus originated the making of sleepingdraughts for(?) the number of slave-girls at the festival of Hat-hồr by all men since that day", ${ }^{3}$. The goddess Hathor is generally brought into connection with the invention of making beer. She is called "she who, first, has made the beer", or, "the inventress of brewing", 107e $8 \Delta 4$. From the temple inscription of Dendera we learn that Hathor is called "the mistress of intoxication", $\square=0$, or even, "the intoxicated one", telyy.t, probably in connection with the myth of the destruction of mankind. Dendera and its temple bore the name "the place of drunkenness", ] $\int_{0}^{0}$ (Düm., Dend.

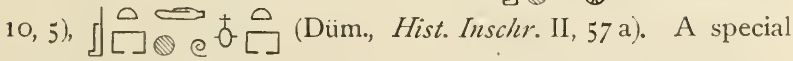
part of Hathor's temple was named "the house of drunkenness", 凹ロ

1) Or read "the miller"(?), see Müller, Max W., Myth. p. 75.

2) Cf. Plutarch, De Iside (ed. Parthey), VI.

3 ) See Müller, Max W., Myth. p. $76 . \quad$ 4) Düm., Kal. Inschr. гоo. 
patron goddess of wine. As the patron goddess of the Mareotic wines she is called "Hathor, the mistress of neha, who resides in hat-u ar-imnt, 㑇 is represented the festive offering of the mnw-jar unto the goddess of wine. Between the king, who offers the wine jar with his right hand, and the goddess, who sits on her throne, there is a long inscription, which contains the songs, which were sung on the 20th day of the month of Thot before the mistress of intoxication during the ceremony of presenting he wine jar to the goddess. With reference to this mnw-jar Hathor is called "mistress of the mnw-jar, whose $k a$ was first prepared on the 20 th day of Thot ${ }^{3}$. This day was the "feast of drunkenness of the mistress of Dendera", 6 The song of the seven Hathors is of especial interest. It reads ${ }^{5}$ :

"We gladden daily thy majesty,

And thy heart rejoiceth, when thou hearest our songs. We shout, when we behold thee,

Every day, every day.

And our hearts rejoice at the sight of thy majesty,

For thou art the mistress of the wreath,

The mistress of the dance,

The mistress of drunkenness without end" 6 .

I) See Düm., Tempel Inschr. I, 73, I. In the same passage she is also called "mistress of the jars, mistress of Yemet," $\nabla=$ toि

2) Mariette, Dendera, I, $3 \mathrm{I}$.

3)

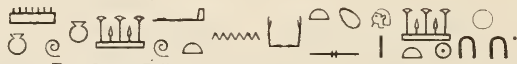

4) Mariette, Dendera, III, 200.

5) Mariette, Dendera, 6o, e-h, = Düm. Res., XLV; see also Junker, H., Poesie aus der Spatzeit, Aeg. Z., 43, pp. IOI-I 28.

6)

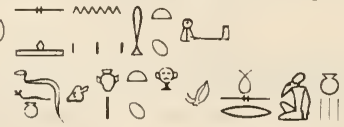


By the side of Hathor appears the goddess Menqet, as a beer-goddess of the Egyptians. Menqet is mentioned as a vegetation divinity, and as such she is orthographically connected with a tree. But later she is shown as a woman holding two (beer?-)jars. She is often described as maker or giver of beer, f. i., "Menqet, the goddess who makes beer", щ $\triangle$ Of m.

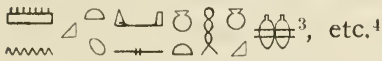

The Classical writers most frequently identified Osiris

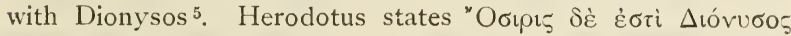

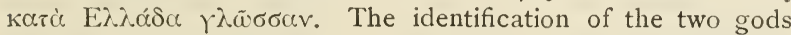
was undoubtedly due to the similarity of the rites of the

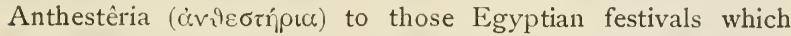
took place in the month Choiak, commemorating the passion and resurrection of Osiris. The holy plant of Osiris as well as of Dionysos was the ivy ${ }^{6}$, but also the vine. The reproduction

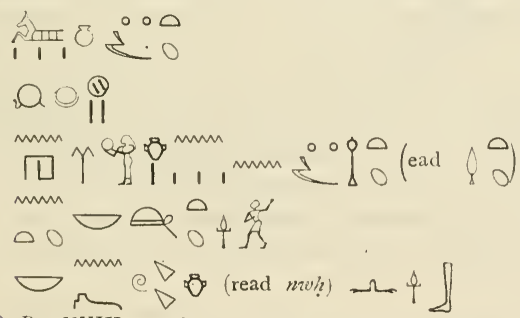

1) Rec. XXIII, p. 167.

2) Lieblein, Livre que mon nom fleurisse, XXXIII, 16.

3) Aeg. Z., 50, p. 42.

4) See further De Morgan, Ombos, No. II2; Mariette, Dendera, II; 6, I5; Piehl, in Mélanges Charles de Harlez, p. 222; v. Bergmann, Buch vom Durchwandeln, $1.7 \mathrm{I}$.

5) Diod. I, II, I3 ff., 96; 1V, I; Plutarch, de Iside I 7, 28, 34 ff., 37; Tibull. I, 7, 29 ff.; Anson. ep., 29-30; Dio Cass. 50, 5, 26; CIG, 4893; Tertull., cor. 7 , etc.

6) Plutarch, de Iside 37. According to Plutarch the ivy was called by

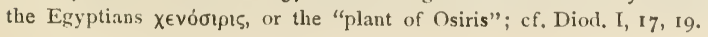

Lutz, l'iticulture and Brewing. 
of vegetation in general, and the fructification of the vine in particular, symbolized to the Egyptians the successive phases of the rebirth of Osiris. In this mystic signification the vineplant figures for instance in the tomb of Sennofri near Sheikhabd-el-Gurnah. The observation made by the Ancients of the vine's reproduction and multiplying without seed, tended naturally to see something divine in this plant. It was, therefore, a befitting symbol of Batau ${ }^{1}$, or Osiris, who revives again, in spite of his mutilation ${ }^{2}$. According to Pyr. 1082 the sky-goddess conceived Osiris by wine. In a bilingual the element רס of the name of a man of Tyre, called corresponds to $\Delta$ เovv́oเo૬, Baudissin, Der phönizische Gott Esmun, ZDMMG, Vol. 59, (1905) p. 485, note 1. A second Egyptian Dionysos was Antaeus, who is known to us only by this classical name Antaeus (or Antaios), and who was. worshipped at Antaiopolis in Middle-Egypt. Also to him the vine or the ivy was holy. Golenischeff ${ }^{3}$ wished to identify him with the Semitic god Resheph, רשט. Rešpu, referring to Plutarch's de Is. et Os., chapter 37, in which it is said that Dionysos is called in Egyptian 'Apбopńs. The god Osiris of the Ethiopians of Meroë has been considered very early as a Dionysos ${ }^{4}$. Also Horus is sometimes identified with Dionysos by the Greeks ${ }^{5}$. A deity, identified with the 16 th decan star, the principal star of the constellation Shesmu ( $\Sigma \varepsilon \sigma \mu \eta)$ is written with the hieroglyph of a press. In Pyr. $\mathrm{P} 707$ he appears to give water and wine. Pyr. T 41 .brings him into connection with a "vine-city". See Müller, Myth. p. 58. Tenemet also seems to have been a patroness of intoxicating drink, according to de Morgan, Ombos No. 65 .

It mar finally be remarked that the misshapen god Bês, of Punt(?), who gained a footing in Egypt as well as in Asia

I) Pap. d'Orb.

2) On the identification of Osiris with Dionysos see Revue des Questions historiques, avril, I 893 and Rec. XX, p. 2 I I ff. See also Müller, Max W., Mytho$\log y, \mathrm{p} . \mathrm{II}_{3}$, fig. II7 Osiris under the vine.

3) Aeg. Z., I 882, p. $138 \mathrm{ff}$. and plates 3 and 4. - Antaeus sometimes in the monuments is identified with Seth.

4) Herod. II, 29 and Origines, c. Celsum V; 37 and 38 .

5) Diod I, I 7 and Plut., de Is. et Os., cap. 37 . 
and the islands of the Greeks, was very fond of drinking and is represented on scarabs as sucking beer from a large vessel in the fashion of the ancient Hittites, the Armenians and early Babylonlans (see Illustration No. 25). He "is no other than the benificent Dionysos, who as a pilgrim through the world, dispensed with hand rich in blessings, mild manners, peace and jollity to the nations" 1 .

The frequent mention of wine and beer in the SumeroAkkadian documents makes it quite certain that the quantities of intoxicating liquors consumed by the ancient Babylonians and Assyrians were enormous. The Babylonians had the reputation of being heavy wine-drinkers, and they surpassed even the Persians in the consumption of wine, who were notorious as winedrinkers ${ }^{2}$. We possess not many documents which refer to drunkenness in Babylonia, but this lies in the nature of the case. The Babylonians, also, were less prone to picture their own vices than the more careless Egyptians. But such docu-
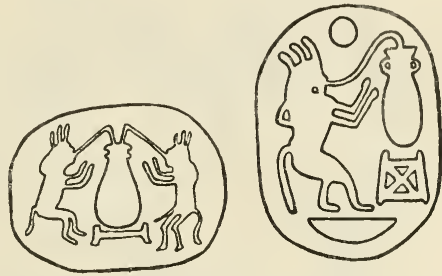

No. 25. God Bês drinking beer through a reed (atter Müller, W. Max, Epyptian Mythol.). ments, nevertheless, have come down to uș. In an Assyrian letter ${ }^{3}$ to the king three armyofficers who had recently been raised to higher military posts, are accused by the writer, Bêl-iqîsha, of drunkenness. The letter reads: "To the king, my lord, thy servant Bêl-iqîsha. May Nabû (and Marduk) be gracious unto the king my lord! The servants of the house of my lord, whom the king, my lord has distinguished to-day, Tabzuâ, son of Bêl-ḩarrâni-ahușur, whom the king my lord has raised to the rank of a major, (and) Nabû-sakip, whom the king my lord has raised to (the rank of) third commander of the regular cavalry, (and)

I) Brugsch, History of Egypt, London, I879, Vol. I, p. II 5.

2) Curt. V, I, 37: Convivales ludi tota Perside regibus purpuratisque cordi sunt; Babylonii maxime in vinum, et quae ebrietatem sequuntur, effusi sunt.

3) K. 613; Harper 85 ; see also VR 54 , No. 2. 
Emur-ilishu, whom the king my lord has raised to (the rank of) body-guard - these three men are drunkards. As soor as they are inebriated, none turns away the iron dagger from him, who is in front of it. The information, which I know, I write unto the king my lord. The king my lord may do as he pleases"1. For a drinking scene in a fortress see the second tent from the left in the middle row of Illustration No. 26. In the right compartment we notice the army-brewer and a huge beer-vessel. In the third tablet of the Babylonian

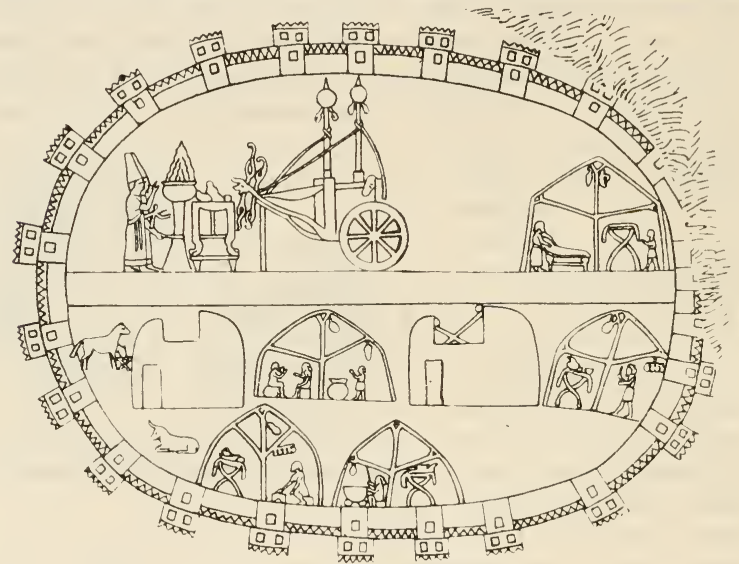

No. 26. Interior of a fortress (after Klio, VI, p. 396).

creation series Anshar speaks unto Gaga, his minister: "Let the gods, all of them, prepare for a feast, let them sit at a

I) A-na šarri be-li-ia (2) ardu-ka m.Bêl-iḳ̂iša (3) Nabû Marduk a-na šarri bêli-ia (4) lik-ru-bu (5) ardâni ša bît bêli-ia (6) ša šarru be-li û-mu (7) an-ni-ú ú-par-ri-su-u-ni (8) m.Tab-zu-a-a mâr m.Bêl-ḩarrâni-ah̆-ușur (9) ša a-na amêluràb ki-șir-u-tu (Io) šarru be-li ú-še-lu-u-ni (II) m.Nabû-sa-kip ša ana amêluIII rakbê (I2) ka-a-ma-nu-tu (I3) šarru be-li ú-še-lu-u-ni (Rev, I) m.Êmur-ili-šu (2) ša ana amêlumutîr-pûtê (3) šarru bêlu ú-še-lu-u-ni (4) III annu-tu șabê (5) ša-ak-ra-nu-tu šu-nu (6) ki-ma i-šak-ki-ru (7) amêlu pațra parzilli (8) ultu pa-an me-hi-ri-šu (9) la ú-sa-ah-ra (Io) a-bu-tu ša ú-du-ú-ni (II) a-na šarri be-li-ia (I2) as-sa-pa-ra (I3) šarru be-li (I4) ki-i sa i-la-u-ni li-pu-uš. 
banquet, let them eat bread, let them mix wine." The closing lines give a vivid description of a banquet of the gods:
ikšašûnimma illak[kûni]
ilâni rabâti kâllišunu mušim[mu šînti]
irubîma muttiš Anšar imlî.....
innisku ahku ahi ina puhri .......
lišânu iškunu ina kirêti [ušbu]
ašnan îkulu iptiḳu [kurunna]
širisa matku usanni beradišu[nu]
sikru ina šatê habașu zum[ri]

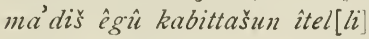

"They came together and went,

The great gods, all of them, who decree fate.

They entered and before Anshar they filled ......

They kissed each other, in the assembly .......

They prepared for the feast, they sat at the banquet;

Bread they ate, strong wine they mixed.

Sweet herb-wine confused their minds(?).

They became intoxicated with drinking, (their) bodies were filled.

They were wholly at ease, their spirit was exalted."

In the recently published version of the Gilgamesh epic Enkidu is decribed in these words: ul idi iluEnkidu aklam ana akâlim šikaram ana satîm lâ lummud, "Enkidu did not know to eat food. He had not been taught to drink beer." From the Assyrian version we know (see Tablet I, 2, 39-40; $3,3-7,33-34 ; 4,3-4)$ that.

"He ate herbs wite the gazelles,

Drank out of a through with cattle."

The woman, who introduces him to civilized life, speaks to him:

akul aklam ilu Enkidu
simat balâtim
šikaram šiti šimti mâti

"Eat food, O Enkidu, the provender of life! Drink beer, the custom of the land!" So "Enkidu ate food till he was satiated. Beer he drank, seven goblets. His spirit was loosened, he became hilarious. His heart became glad and his face shone" 
(see Jastrow-Clay, An Old Babylonian Version of the Gilgamesh Epic, p. 65). Drinking was practised on a large scale at the courts of Babylon and Persia ${ }^{1}$, and Nineveh ${ }^{2}$. From the latter city we possess monumental representations of Assyrian banquets ${ }^{3}$. The banquet scenes represent the guests only as drinking. The sculpture never shows them eating. We see the servants emptying a huge wine-bowl with drinking-cups. The wine-bowl stands on the ground and is of a tremendous

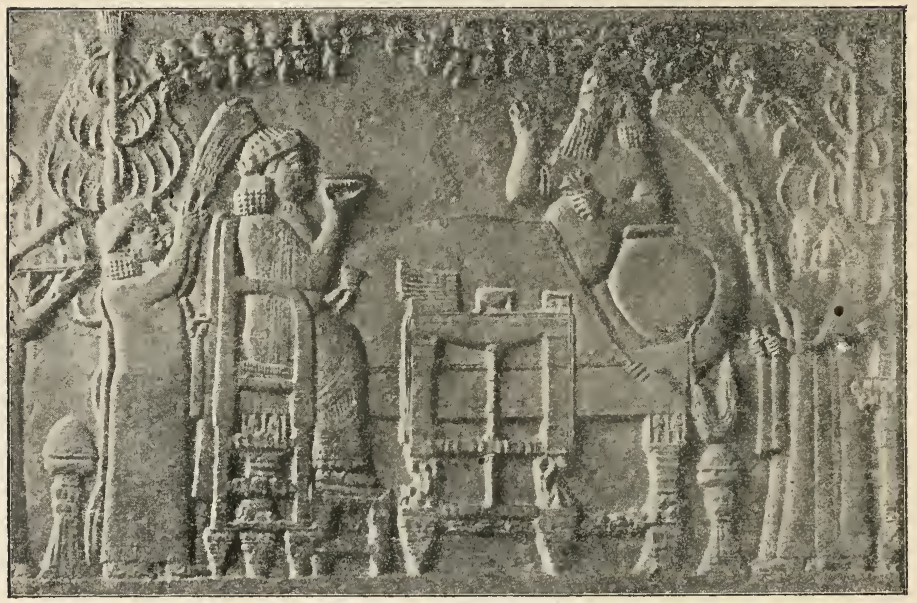

No. 27. Ašsurbanipal reclining in à bower (after Jeremias, Dās Alte Testament im Lichte des Alten Orients).

size, reaching up to a man's chest. The prophet Nahum characterizes the Ninevites as drunkards, saying": "While they are drunken as drunkards, they shall be devoured, as stubble fully dry". Ishtar bids Ašsurbanipal: "Eat food, drink strong wine, make music (and) exalt my divinity," $a-k u l a-k a-l u s i-t i$

1) Htrod. 9, Iro; Daniel 5, 1; Esther 1, 3: Diod. Sic. II, 20.

2) Nahum I, Io.

3) See Botta, Monument, plates 51-67:107-114.

4) Nahum I, 10. 
ku-ru-un-nu nin-gu-túu šú-kun nu-'-id ilu-ti (Assurbanipal, Annals Cyl. B Col. V, 65, 66 and $\mathrm{K} 2652$, Rev. 5). A marble slap from Nineveh, now in the British Museum pictures Aššurbanipal with his consort in a bower, enjoying the precious juice of the grape (see Illlustration No. 27). The Assyrian banquet scenes depict the guests as sitting together in the company of always four on one table, two on each side. Each table had its special waiter. In one case there are depicted some forty or fifty guests present at the banquet. The artist has brought little

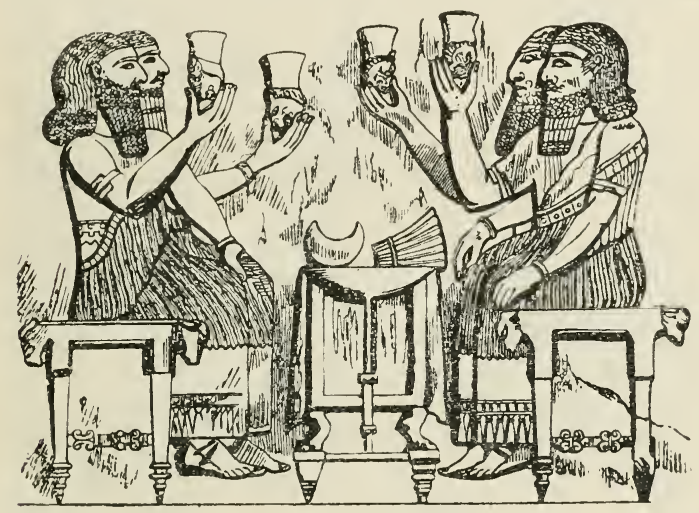

No. 28. An Assyrian banquet scene (after Meissner).

animation into his picture. Each guest is shown in the same pose, holding in his right hand a wine cup, raised to the level with the head (see Illustration No. 28 ). The wine cups are very beautifully worked. They show the form of a lion's head, from which the cup itself rises forth. The Assyrians, as well as the Egyptians reveal a great deal of good taste in the form of their drinking-cups. These cups had different shapes and were made from different material. Herodotus' statement ${ }^{1}$ that the Egyptians drank wine only out of brass

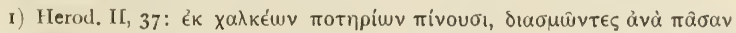

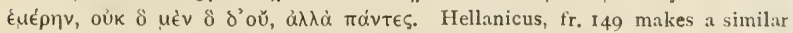
statement. 
or bronze cups is wrong. Joseph ${ }^{1}$, we are told, had a wine goblet wrought of silver, while golden cups are mentioned in the demotic novel (Papyr. Mariette), "and they had set down many golden cups $^{2}$ on the drinking-table. Each of the golden goblets was filled with wine". Also Papyrus Harris pl. 6 mentions vessels of gold for wine and beer. Amongst the many jugs and bowls, there have been found particularly often the $-\square$, ";

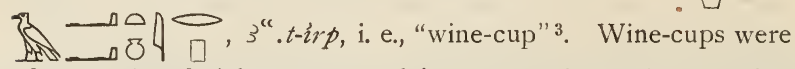
often made of alabaster, porcelain, and perhaps also, judging from the pictures, of glass. They had either the form of an opening flower, which was held in a stand, or contained, like the Assyrian representation, heads of animals, or birds, from whose necks they drank (see Illustration No. 29). A simpler drinking-vessel had the form of our own coffee-cups or saucers (see Illustration No. 30). These latter forms seem to have been most customary with the Syrian neighbors of the Assyrians. In one monument we see representatives of conquered Semitic principalities bringing their tribute of wine in such bowls, while one bears a wineskin on his neck and shoulder (see Illustration No. 31; see also the drinking-scene on the Stele of Nerab; Illustration No. 32). The Assyrians also had musical entertainments with their drinking bouts, as is seen in the banqueting scene of Khorsabad. Two players are playing on ten-stringed lyres, which were of a square shape, and hung around the neck of the musician by a string. Among the high court-officials we meet with the rab $\xi_{a q} \hat{e}$, chief-cup-bearer", or "chief butier" and the rab bappiri, "chief-brewer". These titles were rather honorary, since we find the $r a b$ saq $\hat{\varepsilon}$ employed as military commander, f. i., II Kings 18, 17 "And the king of Assyria sent Tartan and Rab-saris and Rab-shakeh from Lachish to king Hezekiah

I) Gen. $44,2,5$.

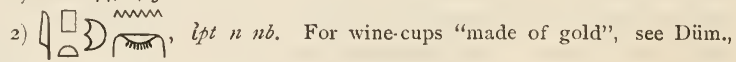
Recueil de mon. Egypt. II, I0, 59.

3) This word represents at the same time a certain measure. On

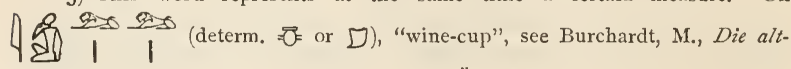
kanaanäischen Fremdworte und Eigennamen in Ägyptischen, Leipzig, 1909-10, 106. 
with a great army unto Jerusalem." On one of the most ancient relics of Sumerian art dating back to the time of UrNina, the founder of the dynasty of Lagash, we see the king in the guise of a laborer, surrounded by his children and the

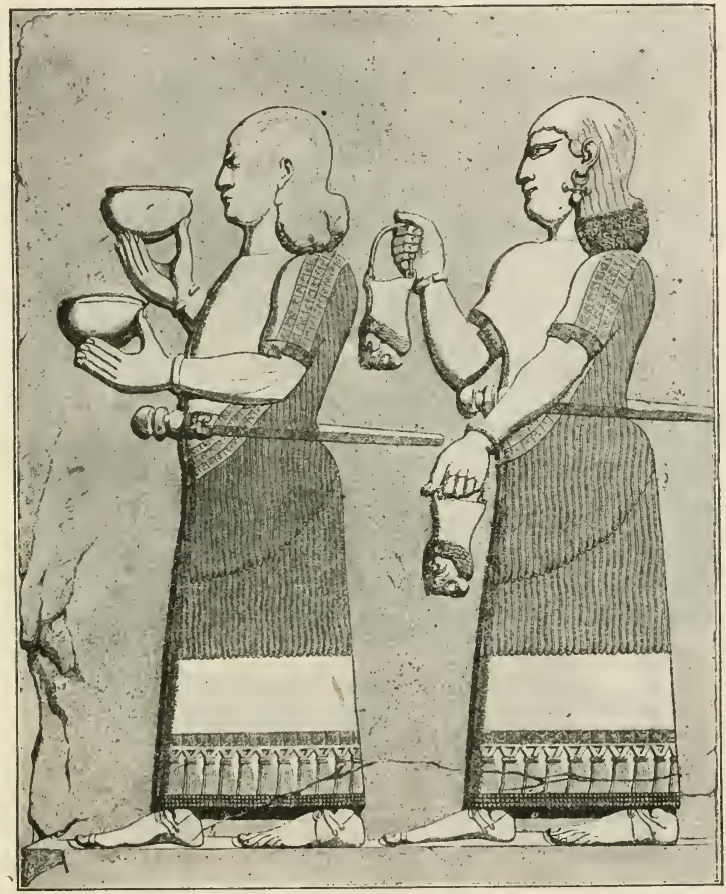

No. 29. Assyrian eunuchs carrying drinking vessels (after Lenormant, Fr., Hist. ancienne de l'Orient).

royal cup-bearer. Thus it appears that this official must have held one of the highest court-positions even at this very early time.

From the cylinders B and C of Urukagina, the last king of Lagash, who stood forth prominently as a great reformer, 


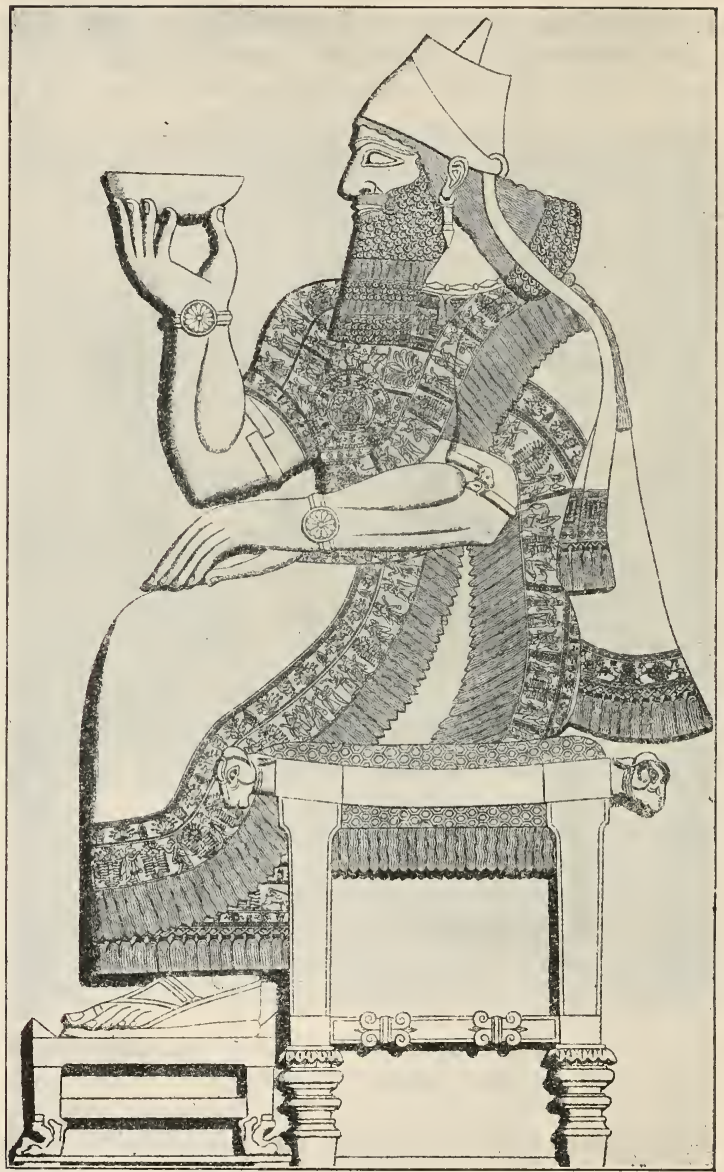

No. 3o. Sennacherib upon his throne (after Lenormant, Fr., Hist. ancienne de l'Orient. 
Wine and Beer in the Daily Life and Religion of the Ancient Orientals, 123

we learn that it was customary for the priests to receive a certain quantity of beer besides other things, when officiating at funerals. "(When) a dead body (was) laid in the grave his beer (amounted to) seven jars", lù-idim ki-mah-šu gub kas-ni $7 d u g$. In Cylinder A, V, $1 \mathrm{ff}$. he narrates what took place after order was again restored". "(When) a dead body (was) laid into the grave, his beer (amounted to) three jars", luidim-idim-a ki-mah-šu gub kas-ni 3 dug. The priests were restricted, by Urukagina's reform, to contend themselves with three, as against formerly seven, jars of beer. In an other

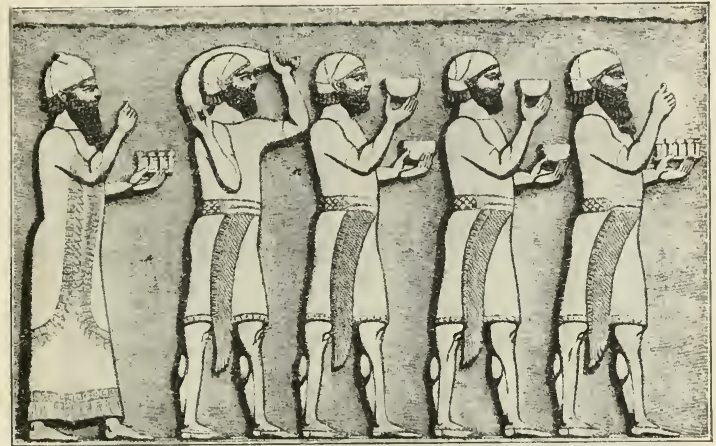

No. 3 r. Representatives of conquered peoples bringing their tribute to the Assyrian king (after Lenormant, Fr., Hist. ancienne de l'Orient).

passage $^{2}$ he fixes the quantity of beer for the lamentationpriest $^{3}$ of Girsu, the lamentation-priest of Lagash, and the artisans. It reads: Two hubur and one amphora of beer for the lamentation-priest of Girsu, 490 loaves of bread, two hubur and one amphora of beer for the lamentation-priest of Lagash; 406 loaves of bread, one hubur and one amphora of beer for the lamentation-priests; 250 loaves of bread, one hubur of beer for the artisans; 180 loaves of bread, one hubur of beer

I) See also Cylinder B and C, IX, $26-X$, i fi.

2) Cyl. B and C X, 2i ff.

3 Ḱầ. 


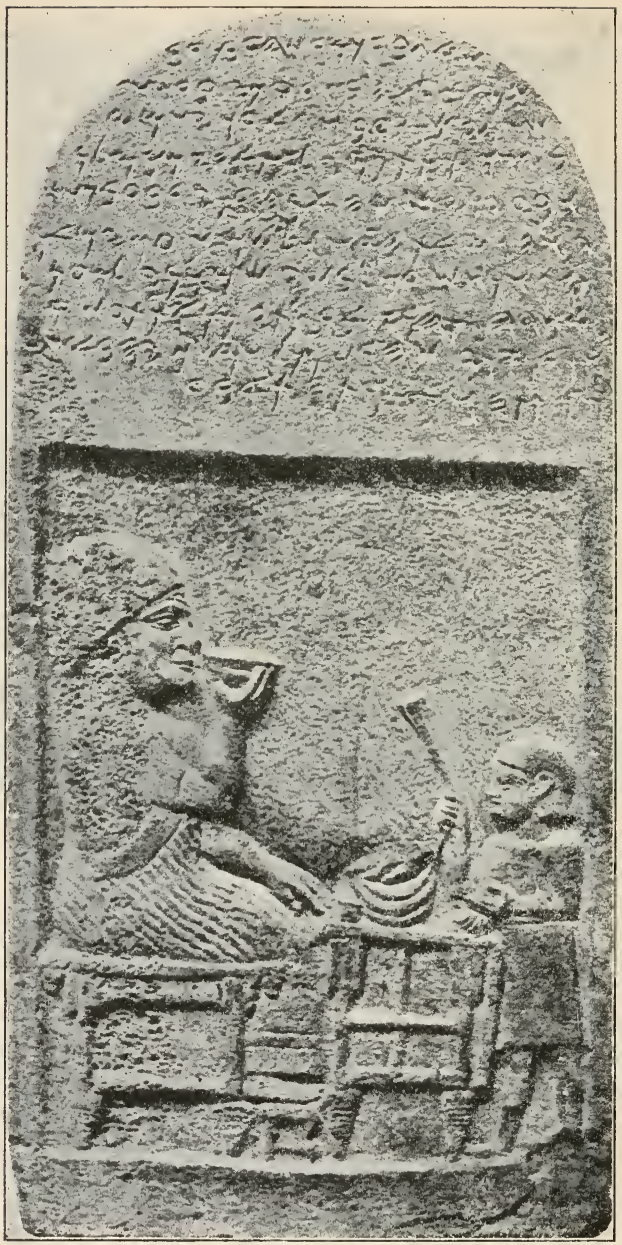

No. 32. The stele of Nerab (after Ball, Light from the East). 
for the ...... of the city of Ninâ" etc. ${ }^{1}$ Hubur and sá-dúg designate in the pre-Sargonic tablets measures of liquids. The specific amount of these measures is not known. The dugmeasure, which was smaller than the $s a^{\prime}-d \dot{u} g$, contained either 20 or $30 q a$, which equalled about 8 to 12 liters. The hubur was again larger than the $s a^{-}-d{ }^{\prime} g g^{2}$. In the oldest periods of the Babylonian history it is known that also the women received their special quantity of wine or beer. One text interests us in this connection, since it shows that wine was drunk by the ladies of the harem ${ }^{3}$. The text reads: "I 30 pomegranate cakes, 40 qa of wine, Etur; 90 pomegranate cakes, $30 q a$ of wine, Urki; 138 pomegranate cakes, 20 fig cakes, 10 qa of wine, Etaë; total: $35^{8}$ pomegranate cakes, 20 fig cakes (and) So qa of wine the gardeners have returned. Shakh, the superindendent, brought it into the harem. Year 1 (of Lugal-anda)".

Wine and beer were offered up as sacrifices to the gods 4 , and Gudea ordered his donkey-shepherd Ensignun "to make plenty beer" 5 for the god Ningirsu. Bel-Marduk received daily six metretes of wine (Hist. Bel. v. 3). The daily wineofferings were presented in gigantic golden chalices. Upon a golden table of offering, measuring 41 feet in length and 15 feet in width, and weighing 500 talents, stood two golden

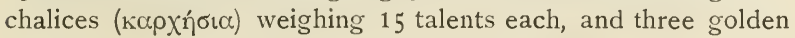
chalices, the one of 1200 talents and the other two of each

I) Cyl, B and C X, 2 I ff.: 2 kas hubbur I sá-düig ušs-ku Gir-suki-kam $60 \times 8+10$ ninda 2 kas-ḩubur 1 sá-dúg uš-ku Širpurlaki-kam $60 \times 6+10 \times 4+6$ ninda $I$ kas hubur $I$ sá-díg us-ku-an $60 \times 4+10$ ninda $I$ kas hubur nam-umma-an $6 o \times 3$ ninda I kas hubur AB.ÁŠs.ŠI Ninâki-na-me.

2) See Zeitschrift f. Assyr., XVII, pp. 94 und 95.

3) H. de Genouillac, Tablettes Sumériennes archä̈ques, No. 43. In Rev. d'Assyr., VI, p. i $34, \mathrm{AO} 4424$, Obv. I ff. (neo-Babylonian) ladies of the palace receive each three $q a$ of spelt-beer as their daily portion. In the sumtotal (Rev. I) it is called, however, kas-ka-lum-ma. i. e., "datewine". See also $\mathrm{AO} 4423$ in Rev. d'Assyr., VI, p. I 34 and often.

4) Gudea, Cyl. B III, I 8; Cyl. B V, 2 I (wine libated in a vessel of lead, bur-an-na mu-tum din mu-ni-dí-dé); Cyl. B VI, 26 (beer- and wine-libation named together, kaš bur-ra dé-da din kaś-a dí-da, "in order that he libate beer, in order that he libate wine with the beer".

5) Cyl. B X, 3 "kaš ha $a-d a "$. 
600 talents (Diod. II, 9). Diodor's account is, of course, exaggerated. Varro (Plin. XXXIII, 15) speaks of a chalice of Semiramis, taken by Cyrus in Babylonia, which only weight 15 talents, while according to Diodorus its weight was 600 talents. Ašsurbanipal, on one of his hunting-inscriptions, is pictured as offering a drink-offering over four dead lions (seeIllustration No. 33). The inscription states: "An offering I offered up over them. Wine I libated over them," muh-huu-ru e-li-šs-nu u-ma-ȟir karâna aḳ-ḳa-a e-li-šu-un. The same king refers to a corner-stone rite of the bit riditi in Nineveh in the following words: "With strong wine and wine I sprinkled its cellar, I poured (it) on its foundation-wall(?)," (Annals, Col. X, $8_{3}-84$

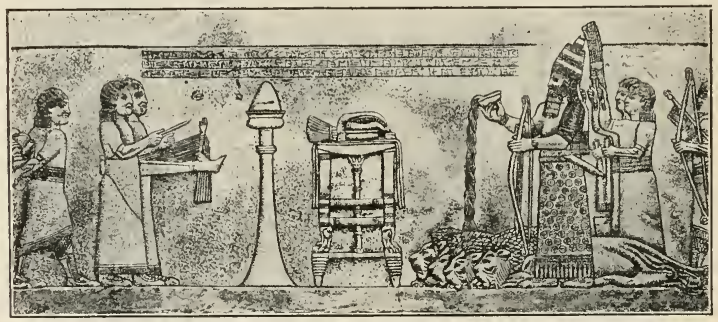

No. 33. Ashurbanipal pouring a drinking-offering of wine over lions slain in the chase (after Ball, Light from the East).

ina kurunni u karâni ka-lak-ka-šu ab-lulul am-ḩa-șa šal-la-ar$\check{s} u$ ). $\mathrm{K} 2674,26$ refers to a libation of wine after the beheading of enemies: "The heads of my enemies I cut off, (and)

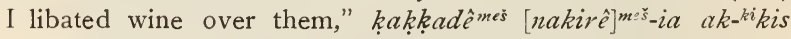
karâna aḳ-ḳa [e-li-šu-nu]. Illustration No. 34 shows king Aššurnàșirpal about to pour a wine libation, after a successful lion hunt. The fermented liquors were conserved in the $\hat{e}$ KAS + NINDA, i. e., "the brewery", or, "the beer-cellar". We have seen above that Babylonia imported much grapewine. The wine was brought from the Eastern mountains in large jars ${ }^{1}$. From a text ${ }^{2}$ it appears that brewers were

I) Tab. pier. d'Uruk II, 6: ê.KA

2) Sippar $123^{\text {bis }}$ (No. 12 in Friedrich, Altbabyl. Urkunden aus Sippara; BA, Vol. V, p. 49I and pp. 422-424). 
drafted into the army, probably to provide the soldiers with beer rather than to serve under arms. It perhaps contains a list of military conscripts, who were called to the colors ${ }^{1}$. In the second tent in the middle row of Illustration No. 26, which pictures a fortress we see in one apartment two sitting men, of whom one is drinking. The second compartment shows a large vessel probably filled with beer.

Babylonia possessed its wineshops and beerhouses ${ }^{2}$, which seems to have been located generally near the water of a river or of a canal. See f. i., Ebeling, $K A R$, I, No. 16, Rev. 35, 36, kar

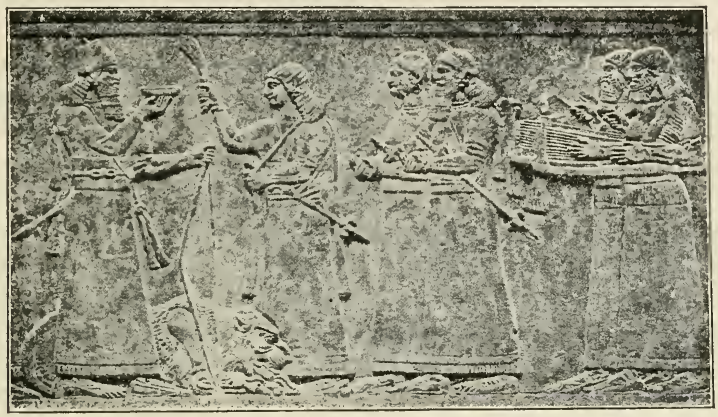

No. 34. Ashurnașirpal about to pour a wine libation over dead lion (after Ball Light from the East).

geštin-na-gè mà ne-in-uš; ina kâr karani elippu um-mid-ma, "The ship stopped at the 'wine-wharf'". See also references below, p. 130, n. 4. The Babylonians, however, considered the frequenting of a public tavern by any respectable person as disgraceful. In a moral text $^{3}$ it is said (line 15): $\forall$ Mm lâ tirrub, i, e., "O lord, thou shalt not enter the beer-house". The same view prevailed, as is well known, amongst the Greeks, for whom it was likewise improper to visit a kapeleion.

1) Date-formula is mu ugnim(ki) ab-nun-naki, i. e., the 32 th year of Hammurabi.

2) For instance, Bu. 88-j-I2, 58 lines 2-3, "bît šikâri"; see Meissner, Beiträge zum Altbabyl. Privatrecht.

3) S. A. Smith, Misc. Texts. 
In Athens, a visit to a tavern was a sufficient cause to bring about expulsion from the Areopagus. According to tradition Kish owed its existence to queen $\mathrm{Ku}$-Bau, who was a woman of obscure and humble origin. It is told of her that she achieved her first popularity and influence as the keeper of a wine shop. There seems to be sufficient reason to believe that the public inns (without exception) were at the same time places of prostitution. The Code of Hammurabi devotes four paragraphs to the regulation of inns, which are called "wineshops". A striking feature of the Code is the fact that it speaks only of female taverners, sal geštin-na, sâbîtu. Men in the liquor-business are not mentioned. But this is merely accidental. The Code may, after all, refer only to such wineshops as were also brothels, kept by women only. Paragraph 108 (Col. XVIII, lines 15-25) makes it clear that it was illegal to accept money for drinks. The price of a drink had to be paid in grain. The taverner was also bound by law to give full measure. Severe punishment was inflicted upon her in case the measure for drink was not in proportion to the measure of grain. The paragraph reads: "If a liquor dealer do not receive barley as the price of drink, but if she receive money by the great stone, or make the measure for liquor smaller than the measure for barley, they shall call that liquor dealer to account, and shall throw her into the water" 1. BM 26961 (King, L. W., The Letters and Inscriptions of Hammurabi, No. 85) illustrates the application of this section of the law-code. King Abieštu $(2042-2015$ B. C.), in a letter to Sin-idinnam. writes: "Unto Ibni-Šamaš, Sin-idinnam, the board of trade(?) of Sippar and the judges of Sippar speak as follows: Thus says Abi-ešû: Messengers and chief-shepherds(?) ..... are going from Babylon to Sippar-Yahrurum. They will reach you on the $24^{\text {th }}$ day of Tišritu. As soon as you see this tablet of mine, buy 300 (kegs) of mixed barley-beer (=pihu from taverners in Sippar-Amnanu, for refreshment(?). When they send you in-

I) šumma salsâbîtum ana šìn šikarim še'am lâ imtaḩar ina abnim rabitim kaspam imtahar $\hat{u}$ maĥ̀r šikarim ana maḩî še'im umtaț salsâbîtam šuâti ukan-

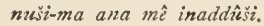


formation, ship the barley(?)-beer to Sippar-Yahrurum. Regarding the barley to be given to the taverners, about which you have written unto me (I reply): It bas been ordered (that) they shall give the barley in Sippar to the taverners." The second paragraph prohibits riotous gatherings in public drinking places and fixes the deathpenalty on the innkeeper in case she does not cause the arrest of the outlaws, "If outlaws collect in the house of the liquor dealer, and she does not arrest these outlaws and bring them to the palace, that liquor dealer shall be put to death"1. The tavern, thus, was a favorite haunt for all kind of rabble that shunned the light. It was a breeding-place for all kinds of crime and the best way for the state to protect itself and its citizens was the imposition of a severe punishment on the innkeeper herself. It would be interesting to know how this law worked in actual practice. The innkeeper certainly was immensely concerned to keep order and not to allow outlaws to make her house a meetingplace or a place of refuge. According to the verbal form employed in the paragraph it would seem that the innkeeper had the power of arrest in her own hands, for otherwise we should expect the causative form, "cause them to be arrested", and, "cause them to be brought". The next paragraph ( $\$ 110$, Col. XVIII, lines $36-44$ ) provides for the punishment on the stake, in case a vestal virgin leaves her house to open a wine-shop or to frequent it for strong drink. It reads: "If a votary, who is not living in a cloister open a tavern, or enter a tavern for a strong drink, they shall burn that woman"2. Only two cases are mentioned in the Code of Hammurabi, in which the horrible punishment of death by burning is ordered. The one referred to above, and the other in $\S 157$, dealing with the heinous crime of incest of mother and son. The last paragraph ( $\$ 111$, Col. XVIII, lines 45-49) regulates the price of liquor sold on time payment. "If a liquor dealer", it states, "give one pîhı-drink

I) šumma salsâbîtum sarrutum ina bîti-ša ittarkasu-ma sarrutim šunûti lâ ișsabtam-ma ana ekallim lâ irdiam salsâbîtum -ši-i iddak.

2) šumma națitum entum ša ina gâgîm lâ wašbat bît sâbî iptete $\hat{u}$ lu ana šikarim ana bît sâhî iterub auviltam šuâtí iqallûšsi.

Lutz, Viticulture and Brewing. 
on credit, at the time of harvest she shall receive 50 qa of barley"1.

Zimmern has recently published ${ }^{2}$ the transliteration and translation of a text, which is of interest in this connection, It contains incantations and rituals, which were intended to increase the business of a taverner, which had for some reason or other fallen off ${ }^{3}$. Two incantations were to be recited by an incantation-priest, while the third incantation, a love charm, was to be used by a demimondaine, or a votary of Ishtar, in order to bring back the lovers, who had stayed away from the inn and the brothel. The text contains an additional proof, if proof were necessary, that the Babylonian inn was at the same time a brothel. All three incantations are addressed to Ishtar, the goddess of love, and possibly also a goddess of beer and wine, like her Egyptian counterpart Hathor. Some passages may illustrate the general character of the text. "O Ishtar, enter at my word, and this tavern let be thy tavern! O Ishtar, support thy hand on the jug and the pressing vat! May profit enter unceasingly, (since) thou takest upon thyself responsibility!" The harlot recites: "Come enter into our house; thy beautiful bed-fellow may enter with thee, (and) thy lover and thy courtesan". The incantation of the harlot ends with the sentence: "As the heaven fructifies the earth (and) plants are plentiful, so may be plentiful the (saying): 'Be sweet unto me'".

In mythology we meet with a divine female taverner, Siduri sâbîtu, who dwells at the "seat of the ocean" ${ }^{4}$ Gilgaše'im iliqi.

I) summa salsâbitum ištên pîham ana qîptim iddin ina ebîrim so qa

2) Zeitschrift für Assyriologie, Vol. XXXIl. pp. 164-is4.

3) Inim-nim-ma šummama mi-ḩi-ir-tum ina bît amêlusa-bi-i par-sat, "Incantation in case that the profit has ceased in the house of the taverner"; inim-

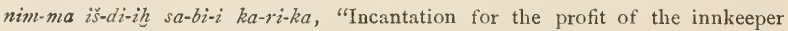
at the dyke".

4) Kussề tâmti; Zimmern, ZA, Vol. XXXII, p. I69 explains this phrase quite naturally, by referring to the sâbî kâri, "the innkeeper of the dyke" and to the si-bi-'-i $k a-a-r i$ in Gray's Hymn to Šamaš, Col. III, 45 (- Jensen, $K B$, Vol. VI, 2, I, p. I04) and $Z A$, Vol. XXXII, 114, 16. See, however, also Albright ( $A \mathcal{F} S L$, Vol. XXXVI, p. 260) who considers the phrase "a very curious detail". 
mesh in his burning quest for eternal life, having passed the abodes of men, finally reached the gate of the sun. Giant scorpion men guard this gate. $\mathrm{He}$ is unwillingly admitted to pass on the dark road of the sun. He travels for twentyfour hours, and at last he comes to a beautiful vineyard.

"Amethyst it bore as its fruit,

Grape-vine was trellised, good to behold;

Lapis-lazuli it bore as grapé-clusters, Fruit it bore, magnificent to look upon"1.

Gilgamesh meets Siduri, the taverner, in this her vineyard. The vineyard is her domain, the vinestalk the tree of life and the noble and precious fluid, which she prepares, the means of imparting eternal life. As the Babylonian female taverner was primarily concerned with the preparing of beer or wine, and secondarily with the serving of beer or wine ${ }^{2}$, so Siduri, the taverner, is described as engaged in the preparation of wine. To this purpose "they have made her a jar, they have made her a pressing vat" 3 .

One of the oldest divinities of the pantheon of the ancient Sumerians was a vinegoddess, called dingirGeštin ${ }^{4}$, or also, dingirAma-geštin, i. e., "the mother vinestalk". A temple was dedicated to her in the city of Lagash, which is mentioned in an inscription of Urukagina ${ }^{5}$. At a very early date, however, she loses all characteristics of a vinegoddess, and appears as the goddess Ninâ, "the lady of the waters". This was but natural, when we consider, how little vine was cultivated in Babylonia, on the one hand, and on the other,

1) sâmtu našât inib̌sa

ișhunnatum ullulat ana dagâla țâbat

uknî̀ našî hashalta

inba nas̀ì-ma ana amâri sa'âh.

2) Schwenzner, Altbabyl. Wirtschafisleben, p. 25 ff. (MVAG, 1914, I1I).

3) Gilgamesh-Epos, Tablet $\mathrm{X}, 3$ : epšsušsi kannu epšuši namzîtu. On the restoration nam-zi-tu see Zimmern, 1. c., p. 169.

4) Or dingirMu-tin and dingirMu-ti. As the consort of the god of heaven she is later called Geštin-anna, "the vinestalk of heaven", or Mu-tin-an-na.

5) Urukagina, Clay Tablet, Rev. II, I and 3. 
how important a role water and irrigation played in Babylonia ${ }^{1}$.

A vinegod appears by the name dingir Pa-geštin-dug ${ }^{2}$, "the good vinestalk", whose consort was dingirNin-kasi, "the lady of the inebriating fruit", also called dingir Ša-bil, i. e., "she who causes burning". She is also mentioned by the name dingir Kaštin-nam, "the intoxicating beverage, which decreed life". As her mother appears the goddess dingirNin-til, "the lady of life". dingirŚa-bil is the mother of nine children ${ }^{3}$, who seem all to have some connection with intoxicating drinks, or describing an effect of the use of alcoholic beverages. In the list dingirSirîs is mentioned first. Her name refers to "beer" or any intoxicant not prepared from grape-vine. This goddess is followed by dingirŠ IM + KAS š a certain kind of beer prepared of barley and an addition of spices, and dingir bably a dark kind of beer. The names, which follow, describe the effects of beer or wine. Here we meet with dingirMe-huš, who may perhaps best be translated by "the brawler", literally, "he of frightening speech". The fifth child is called dingi.Meazag, i. e., "he of a clear speech"; the sixth, dingirEme-te, i. e., "he of an eloquent tongue"; the seventh dingirKi-dur-ka-zal, i. e., "he of the abode of mirth"; the eighth, dingirNu-silig-ga, i. e., "the braggart", or, "the boaster", and the last, dingirNinma-da, i. e., "the lord of the land". Ninkasi lives on Mount Sàbu, which, of course, is not a geographical designation, but means either "the mount of the taverner", or, "the mount of retailing (scil. beer or "wine)" 4 . The god Ninurta, at least in one instance (see Meissner, Altorient. Texte und Untersuchun-

I) For wine in the incantation literature see Ebeling, $K A R I$, II, No. 62 , lines I0-13. karamu ui-paț-ra qablê-ka lišs-ša-pah šepêt-ka dan-mu ki-ri-mu-ka li-ir-mu-ka.

2) See CT XXIV, Io, $22 \mathrm{ff}$.

3). They are salled ilimmu-ám dumu-meš dingirNin-ka-si-gc̀ muš-lah-lahe-ne an-na-gè, i. e., "they are the nine children of Ninkasi, the "snake-drivers" of "heaven".

4) Ninkasi is called in CT, XV, 4I, 24: geme-tug-tug dagar-ra-me-tegar = sinnišstu itpišstu ummu ša ana simâti šaknat, i. e., "the clever woman, who tends to the giving of drinks". Simâti seems to be etymologically con-

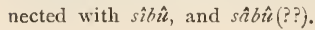


gen, I, 279, 39) is referred to as one who knows "well to prepare strong wine."

In passing on to Palestine, we may finally remark that the Babylonian literature has not yet produced anything like moral prescription in which a warning is contained in regard to the excessive use of alcoholic beverages. That such "proverbs", however, were existent is seen from such passages as: pukli na’pi meštû ul uhhuršu, i. e., "(as for) the strength of the worm, the drunkard is not inferior to it" 1 .

The Hebrews, like their neighbors, appreciated wine, and no festivity was held without it, for the very name "festivity" - mishteh, points to this ${ }^{2}$. Numerous passages in the Old Testament praise the vinestalk and its fruit. "Wine cheers man's heart" 3 , yea even the gods ${ }^{4}$. It is indispensable at the meals of the Hebrews ${ }^{5}$, and was not allowed to be missed on the altar of Yahweh as a drink-offering. Drunkenness was by no means unknown to them ${ }^{6}$. Only the Rekhabites and the Nasiraeans abstained from its use. The majority of the people, probably, always regarded wine with favor. The numerous wine-presses still testify to that. The religious leaders, of course, took quite another view-point, regarding the use of wine ${ }^{7}$. During the early days of the history of Israel, no opposition from that side was as yet encountered. But it soon set in. Viticulture represents a higher form of culture, which, like every other form of an advanced stage of human progress, was looked upon with disfavor. The simple beduin

I) II R I6, lines 23-24 d; see also BA, II, p. 296. Cf. Sir. 34, 30"(wine) diminishes the strengthj', $\pi=\neg[0]$ מת.

2) This designation occurs first in Gen, 21,8 . It becomes more common, however, at a later time. It is strange that in the story of Abraham's reception of the strangers (Gen, $18,6-9$ ), and even at the mention of the deliveries for the royal court of Solomon, only bread and meat are mentioned ( I Kings 5, 2, 3) but not wine, while the possesssion of a privately owned vineyard is ascribed to every citizen (I Kings 5, 5).

3) Psalm 104, 15. Sir. 40, 20a: "wine and beer gladden the heart",

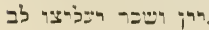

4) Judg. 9, 13. 5) I. Sam. 1, 9. I3.

6) I. Sam. 25,36 ; I, I 3 ; II. Sam. I I, I 3 ; Jer. 5,$22 ; 23,9$; Hos. 7,3 ctc.

7) On a discussion of the "Wine in the Pentateruchal Codes", see Jastrow in $7 A O S$, Vol. NXXIII, pp. rso-r92. 
life of the nomadic patriarchs was the ideal life to which Israel's religious leaders looked back. Each step of an advance to a more refined mode of living is a step farther away from Yahweh. To warn against viticulture and wine-drinking is narrated an occurrence in the family of Noah ${ }^{1}$, and another in the house of Lot, in which the use of wine led to shameful intercourse with his two daughters ${ }^{2}$. The lawgiver permits parents, whose son is living in debauchery and is a drunkard to accuse him to death before the judges ${ }^{3}$. This is an extraordinary ordinance, which stands without parallel. Drunkenness, for instance, is never mentioned in the Code of Hammurabi, or any other legal regulations of Babylonia and Assyria. This fact is significant and tends to show that drunkenness was not considered a crime by the Babylonians and Assyrians. On the other hand, Deut. 21, 20 permits the most severe punishment to be imposed upon the drunkard. The Ancient Orient otherwise knows no punishment for intoxication. A change was wrought in this respect by the introduction of Islâm. The Muhammadan law provides for forty beatings in case of drunkenness. They could be augmented up to eighty strokes in case of habitual drunkenness ${ }^{4}$. The Hebrew lawgiver forbids the priests to partake of intoxicating drinks during their services ${ }^{5}$. The assumption of the preexilic Hebrew leaders is that he who drinks wine necessarily becomes inebriated. This is still evident in a later period of Hebrew history. There is preserved a pleasant song, in which the mother warns the royal prince of wine-drinking ${ }^{6}$ :

"It is not for kings to drink wine,

Nor for rulers to mix strong drink;

Lest, drinking, they forget the law,
I) Gen. 9, 2I ff.
2) Gen. I $9,32 \mathrm{ff}$.
3) Deut. 2I, 20.

4) Mâwerdî, 388 . Cf. also Lane, An Account of the Manners and Customs of the Modern Egyptians, 5 th ed., London, 1871, p. 137: "Drunkenness was punished, by the Prophet, by flogging; and is still in Cairo, though not often: the 'hadd'; or number of stripes, for this offence, is eighty in the case of a free man, and forty in that of a slave."

5) Levit. Io, 9.

6) Proverbs, 3I, 4-7, given according to Toy, Critical and Erangelical Commentary on the Book of Proverbs, p. 539. 
And disregard the rights of the suffering. Give strong drink to him who is perishing, Wine to him who is in bitter distress; That, drinking he may forget his poverty, And think of his misery no more".

Motive and close of the admonition are equally interesting. The Book of Proverbs takes a decidedly unfavorable position to wine. "Wine is a mocker, strong drink a brawler" ${ }^{1}$; "he who loves wine and oil will not be rich" ${ }^{2}$; "look not on wine when it is red, when it sparkles in the cup"3; "thou shalt not be with the wine-bibbers, with the gluttonous eaters of flesh, for the drinker and the gormandizer shall impoverish, and drowsiness shall clothe a man with rags" 4 "Who crieth: 'Woe'? who: 'Alas'? Who hath contentions? who hath raving? who hath wounds without cause? who hath redness of eyes? They that tarry long at the wine; they that go to try mixed wine" 5 . The opposition, however, from the religious leaders, becomes weaker as the time passes on. The establishment of the kingdom, which marked a real political and material progress in the history of the Hebrews, but making also higher claims regarding the mode of living, undermined the ultra conservative position of the religious leaders, and by the end of the seventh century the opposition towards wine and other intoxicants had ceased. In post-exilic times only the excessive use of alcoholic beverages is condemned ${ }^{6}$. It is now considered as a distinct blessing of God, when the vine-harvest showed a good crop and the winecellars could be fully stored with wine. Sir. 30, 25: "I stood in the blessing of the Lord, and like a gatherer I filled my wine-press." According to Jastrow 7 "the later view of postexilic Judaism is reflected in the juxta-position of 'bread and wine', as the accessory to the blessing formula in Gen.

I) Prov. 20, I. $\quad$ 2) Prov. $21,17 . \quad 3)$ Prov. $23,31$.

4) Prov. 23, 20-2r. 5) Prov. 23, 29-30.

6) In spite of all the bad experiences of Judah with wine, be does not prohibit the use it, but only warns against its excessive use. (Sec Das Testament Fudas, p. $47 \mathrm{I}$ ff. in Kautzsch, Die Apokryphen und Pseudepigraphen, Vol. II).

7) F.AOS, Vol, XXxiII, p. I\$2. 
14, 18". Also the stereotyped phrase, characteristic of Deu-

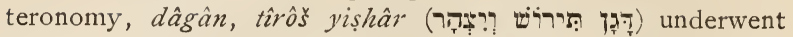
later a change due to the view taken by the post-exilic prophets towards wine. In place of tîrôs, which according to Jastrow "represents a preparation of the grape-juice in a less advanced stage, than the finished fermented product" the word yayin was inserted ${ }^{1}$. This, of course, does not imply that at the time of the Deuteronomistic writer "the process of manufacturing a thoroughly fermented article had not yet been perfected" 2 , but that for quite another reason yayin was not used in a phrase, which summed up the products of the land. In this phrase tîrôs is used, with means "new wine". Each year the land yielded "corn, new wine and oil", but not yayin, which refers to "old wine", and which was the product of the land of former years. Yayin was introduced due to a change of view taken towards strong old wine, it is true, but the change to yayin is really less correct than the tirôs of Deuteromy.

Sir. 9, 10, 11 likens new wine to a new friend: "Do not give up an old friend, for a new one does not equal him. New wine is a new friend, when it becomes old, then thou mayest drink it."

$$
\begin{aligned}
& \text { אל תש אורהב ישן }
\end{aligned}
$$

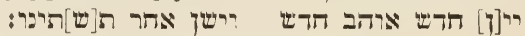

Cf. here Alcharisi's Tachkemoni (p. 70b):

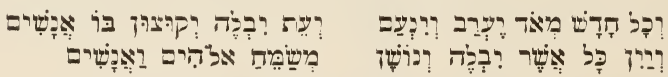

No feast was considered to contain true joy for men unless it was celebrated with wine, while women found their pleasure rather in beautiful dresses (bPesach 109a), although custom permitted women to drink wine, as f. i., in the example of Hannah. Wine nourishes (זירי), refreshes ( (זמח) (bBerakh 35b; cf. also bSukka 49b). Wine is the foremost of all medicines; wherever wine is lacking, medicines become necessary. Sir. 34, 27, 28: "Wine is like water of life

1) And instead of dâgân (corn) hițțim and in place of yişhar, šemen.

2) See Jastrow, p. I8 3 . 
for man, whenever he drink it moderately. What is life for him who is without wine, since it is destined from the beginning for joy! Joy of heart and jubilation and life of pleasure is wine, which is drunk at the right time and for satiation."

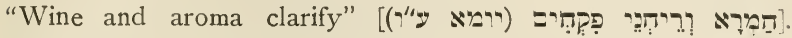
But the use of wine may become also dangerous. Sir. 34, 29: "Headache and shame and ignominy is wine, which is drunk in quarrel and anger. Wine often brings the fool to ruination, it diminishes the strength and multiplies the wounds." Sir. 34, 25: "The must has killed many." "Man is known by three things: by his (wine)-cup, by his purse and by his

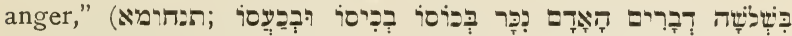

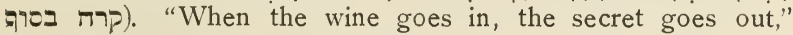

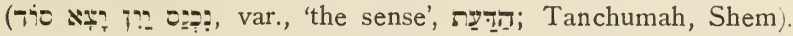
He who sings Bible-verses in the tavern has no part in the eternal blessed life (Sanh. 101 a):

The Hebrews seem to have practised a good deal of luxury at the banquets of the rich and at the royal court. Solomon, we are told, had golden drinking vessels ${ }^{1}$. Jere-

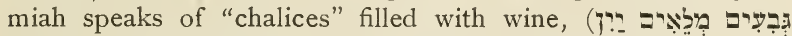
sioj), with which were given drinking cups, probably in order to take out the wine with them from the chalice, as was the fashion in Assyria. This indicates that the wine was served in large chalices, similar to those in Assyria. In the time of the prophet Amos wine was drunk also from flat dishes, or flat bowls ${ }^{2}$. These flat wine-bowls, it seems, were an object of bitter reproach of the prophet, since they let the spirit of wine evaporate quickly and thus necessitated faster drinking, which led so much more readily to debauchery.

The public inns of Palestine, we may conjecture from the story of Rahab, had the same evil reputation as those of Babylonia. Rahab, the innkeeper was at the same time a har$\operatorname{lot}^{3}$. The public inns were attended by singing-girls, who played some kind of musical instruments. Cf. Sir. 9, 4: "Do not have intercourse with a cither-player in order that thou art not caught in her snares."

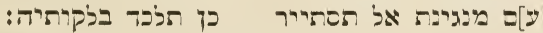
I) I Kings 10,21 .
2) $A \operatorname{mos} 6,6$ פיר
3) Joshua 2, I. 
(Smend, Die Weisheit des Fesus Sirach, Berlin, 1906). In view of conditions in Arabia, we may judge that these singing-girls in Palestine constituted a large, if not the largest, class of prostitutes. Here as well as in Arabia she was a foreigner, a $\pi$, which means both the foreign woman and the harlot (Prov. 2, 16; 5, 3; 5, 20; 7, 5; 22, 14; 23, 27). The Palestinian

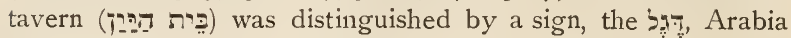
غئَ (see below p. 149). Correct singing at drinking-bouts ${ }^{1}$ is likened to a seal-stone of carbuncle on a golden neck-chain and to a seal-stone of emerald, Sir. 35, 5, 6:

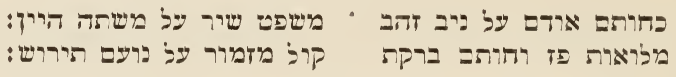

The custom of the Greeks and Romans, to wreath oneself at banquets, had been introduced also by the Jews (Wisd. 2, 8; cf. Is. $28,1-5$ ). Johns ${ }^{2}$ has pointed out that there exists a striking parallel between the Code of Hammurabi and Lev. 21, 9. Death by burning is decreed to the daughter of a priest who is unchaste. The Code, we have seen above, mentions the horrible punishment only twice, but so does Hebrew legisla. tion, and in the same cases. Josephus directly states that in the case of the priest's daughter it is not unchastity alone that brought upon her this fearful punishment of burning, but this punishment was imposed upon her in case that she at the same time opens a tavern. The Talmud seems to indicate that the rabbis also connected the crime of the priest's daughter with the tavern, for they ask: Shall not a priestess or priest's daughter be treated better than a tavern-keeper? There appears to have remained thus in Talmudic time a recollection that in certain circumstances the law had prescribed the death-penalty by burning for innkeepers.

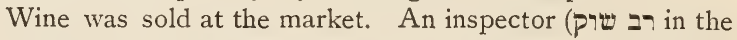

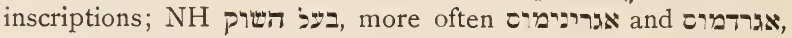
i. e., çropavónos) who controlled the market-prices and weights and examined the provisions and the grain, tasted (av) the

I) The name of Josiah is likened to a song at a wine drinking-bout (Sir. 49, I).

2) Johns, C. H. W., The Relations between the Lares of Babvlenir and the Laws of the Hebrew Peoples, The Schweich Lectures, I9I2. 
quality of the wine by means of a reed, a siphon or a special cup, or by simply smelling the wine. The price of wine was

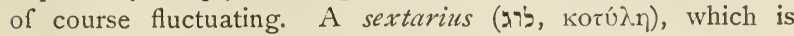
32 ounces, i. e., one quart, of common tavern-wine cost four pieces of the small coin lumi (לומין, voupuior, nummus). According to another reckoning a sextarius of wine cost ten

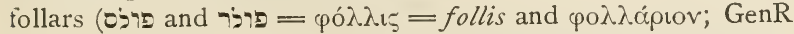
49, 4; LevR 27, 2). Wine was drunk to excess at weddingfestivals (bBerakh 9a, ibid. $6 \mathrm{~b}, 30 \mathrm{~b}$ etc.) and at funeral-feasts it was not missing, but in order to prohibit over-indulgence, ten cups of wine were the maximum set for the seven days of mourning. The slaves, in Rabbinic times, had the reputation of often being drunkards, and "the slave, who frequents

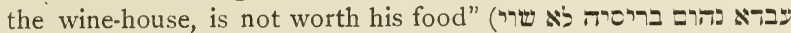
$\mathrm{bBm} 64 \mathrm{~b})$. The effects of chronic alcoholism are mentioned neither in the Old Testament nor in the Talmud. A legal distinction was made between the sathîy, the person slightly intoxicated, and the šikkor, the person totally drunk (Erub. 64a; Erub. 65a; Eben haezer 44, 3 and Choshen hamishp. 235, 22). Aged wine, according to Ned, IX, $8(66 \mathrm{~b})$ is beneficial to the intestines, while new wine is harmful. As a rule, unmixed wine should be drunk after letting blood, but in case one is unable to buy wine, seven black dates should be eaten instead (Sabb. 129a). Wine was also used as an application (Sabb. 109a). In Northern Syria the custom seems to have prevailed of sipping beer or wine through a long cane directly out of a large vessel, in which the liquor was brewed. On a tombstone $^{1}$ of a Syrian mercenary found in Tell el-Amarna this custom is proved for Syria in the fourteenth century B. C. This custom prevailed amongst the Hittites and the peasants of the Armenian mountains. In the cylinder of black serpentine, which was found in Kueltepe, the main-scene shows two seated men, who drink barley-beer through a long reed. The same custom of drinking appears in Babylonia in the oldest time $^{2}$, but seems to have been unknown amongst the Hebrews.

I) Berlin Museum, No. I4 I22; see plate 17 , facing p. 126 in Aeg. Z., Vol. ${ }^{6}$.

2) See Ward, Seal-Cylinders, Nos. $83,84,85,86,87,88,95,99,732,734$ and $73^{8}$. 
Wiedemann, in $O L Z, 1901$, Vol. IV, 7 drew attention to the fact that the Armenian tubes for sucking beer differed in so far from those used in Egypt, as Xenophon states regard-

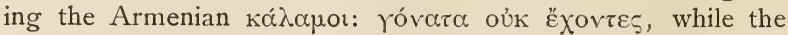
Egyptian tubes possessed the Yóvv. Drinking-tubes were probably used in order to avoid swallowing the particles of yeast, which gathered on top of the brew (see OLZ, 1900, Vol. III, 307), as well as the barley-grains.

Yahweh the austere god of the Hebrews, strange as may seem, was identified in Classical times, with Dionysos, the god of wine and merry life. In the Symposion of Plutarch ${ }^{1}$, it is stated by one who is initiated into the Athenian Dionysian mysteries, that the god of the Hebrews is the same as Dionysos. He makes this assertion on account of the fact that the Hebrews commence other festivals some days after the feast of the tavernacles, which they themselves call those of Bacchos ${ }^{2}$. Movers ${ }^{3}$ explained this statement in Plutarch by referring to the Hallelu-yah shouts at the feast of the tavernacles, which lasted for eight days. The Athenian, thus, was led to his statement on account of the Hallelu-yah shout which reminded him of the iaxeiv, i. e., the iav-shout of the Dionysian rites. Baudissin ${ }^{4}$ has shown beyond doubt that the identification of Dionysos with Yahweh is due to misunder-

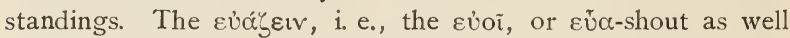

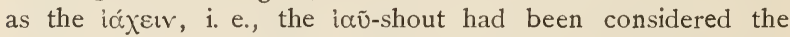
same rite as the $Y a$-shout, i. e., the Hallelu-yah of the Hebrew priests, while on the other hand, the thyrsos-staves of the festivals of Dionysos were wrongly brought into connection with the palm- and myrrh-branches of Jewish festivals. The feast of the temple-dedication, particularly, according to II. Macc. 10, 7, at which hymns were song, while carrying thyrsos-staves, palm-branches and other branches, was responsible for this mistake of identification. Tacitus ${ }^{5}$ also mentions

I) L. IV, 6, 2 .

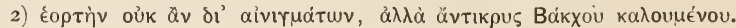

3) Movers, Die Phönizier, Bd. I.

4) See Baudissin, W. W., Studien zur Semitischen Religionsgeschichte, Leipzig, 1876; III. Der Ursprung des Gottesnamens 'láw, pp. I 81-254.

5) Hist. 1. V c. 5 . 
Wine and Beer in the Daily Life and Religion of the Ancient Orientals. 141

this confusion of the ceremonies, but he rejects it: .... quia sacerdotes eorum ${ }^{1}$ tibia tympanisque concinebant, hedera vinciebantur, vitisque aurea templo reperta, Liberum patrem coli, domitorem orientis, quidam arbitrati sunt, nequaquam congruentibus institutis: quippe Liber festos laetosque ritus posuit, Fudaeorum mos absurdus sordidusque.

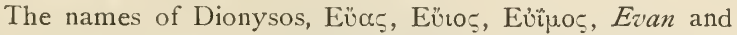

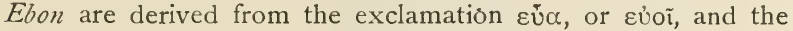
name Iacchos ("I $\alpha_{\chi}{ }_{0}$ ) from the Homeric ióxeıv, "to call aloud" 2

While the identification of Yahweh with Dionysos must be rejected, there is a strong probability of identifying the Phoenician god Esmun with Dionysos ${ }^{3}$. Dionysos appears on coins of Tyre ${ }^{4}$ since the time of Seleucus IV (167-175 B. C.) and on coins of Sidon ${ }^{5}$ since $111 \mathrm{~B}$. C. In the time of the emperor Gordianus the representation of Dionysos appears also on coins of Berytos ${ }^{6}$. A Hittite wine-god appears in Illustration No. 35.

According to Baruch II, 4, the tree that seduced Adam was the vinestalk. It was planted by the angel 'Samael'. This angered God, and he cursed it and did not permit Adam to touch the plant. But Satan seduced Adam through the vine. The vine was swept away from Paradies through the waters of the flood, but it was not completely destroyed. Noah found the plant after the Flood. He was troubled in his conscience whether to make use of the plant or not. In order to ascertain the will of God regarding it he prayed for forty days. Finally God sent his angel Sarasael with the permission

I) Scil. Judaeorum.

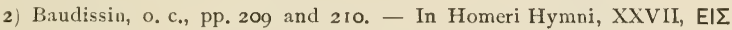

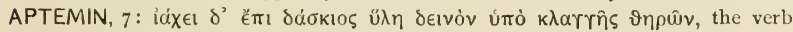

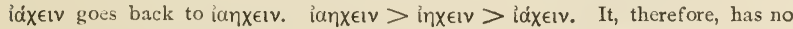
bearing on the question.

3) See Baudissin, Der phönizische Gott Esmun, ZDMG, Vol. 59 (Igo5), pp, 432 439.

4) Rouvier, Fourn. Intern. d'archíol. numismat., Vol. KI, p. 279, n. I 829 -1835 ; Vol. VIJ, p. $76^{\circ}$ n. 2366.

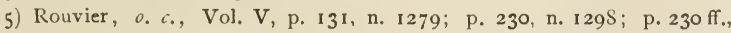
n. 1299 -1302; p. 245, n. 1397 ; p. 248, n. 1417 ; p. 248 ff., n. $1418-1437$; p. 267 ff., n. $1528 ;$ p. 277 , n. $1573 ;$ p. 282 ff., n. 1613 and 1614 .

6) Rouvier, o. c., Vol. III, p. 307 ff., n. 603-606. 
to plant the vine. Tanchumah, Noah contains the story as to what happened at the time when Noah was about to plant the first vineyard. "When Noah began to plant the vineyard came Satan up to him and said to him: 'What art thou planting?'; he said to him: 'A vineyard'. 'What are its properties?'.

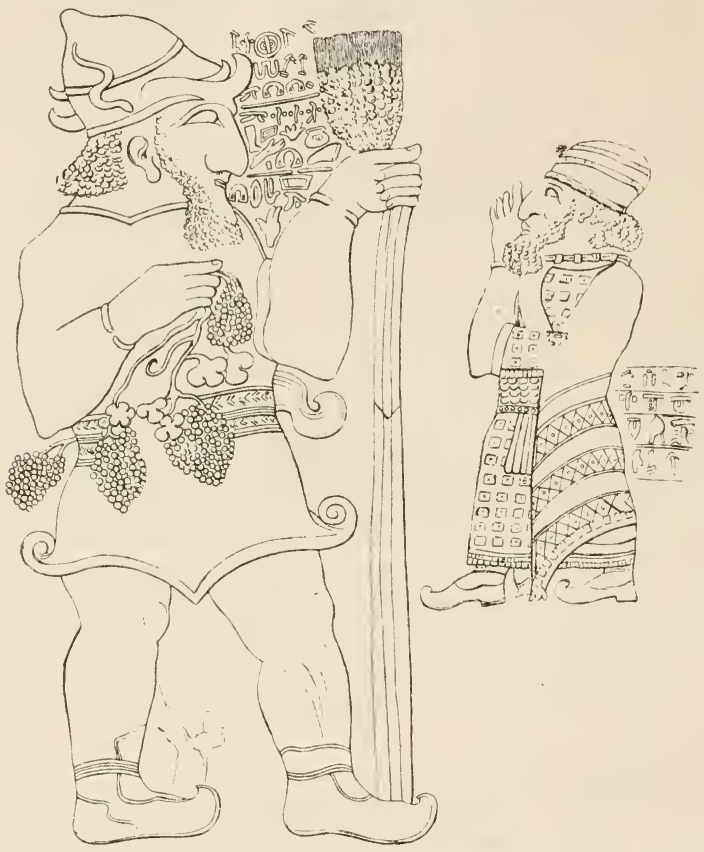

No. 35. Rock-sculpture at Ibrîz - a king or noble worshipping a god of corn and wine (after Ball, Light from the East).

'Its fruits are sweet and pleasant, green as well as dried; and wine is made from them, which gladdens the hearts, as it is written: 'Wine gladdens the heart of man' (Ps. 104, 15). Satan said to him: 'Come on and let us both lay out this vineyard'. ,Alright' he said. What did Satan do? He brought a lamb 
and killed it under the rinestalk, and again he brought a pig and killed it and again he brought a lion and killed it, and again he brought a monkey and killed it under the vine and caused the blood to drip on the vinestalks, and they were moistened from their blood. He indicated thereby, that man, before he has drunk of the wine, is innocent like a lamb, which knows nothing and like a sheep that before its shearers is dumb (Isaiah, 52,7 ). Has he drunk moderately, (then) he is strong like a lion, and is saying that none is like him in all the world. Should he drink wine beyond measure, he will become like a pig, trodding about in the mire and if he has become drunk, he will act like a monkey, jumping about and speaking filthy

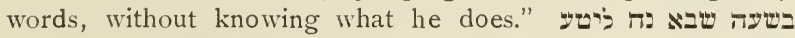

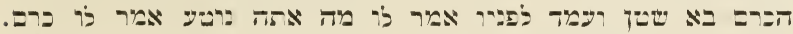

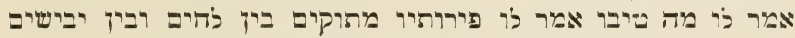

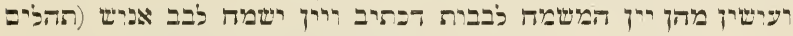

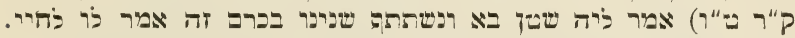

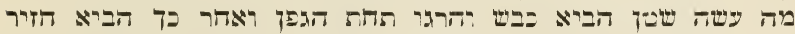

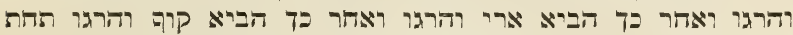

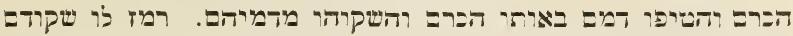

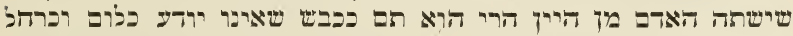

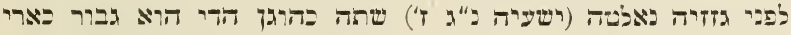

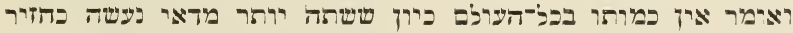

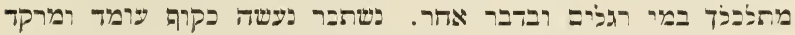

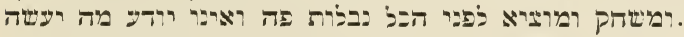

Pre-Islàmic Arabia has left us sufficient material to form an idea of the use of wine in that country. Our sources are exclusively Old-Arabic poems. Wine-drinking was a habit freely indulged in by the pre-Islâmic Arabs, and no old poem, which pictures the daily life of the Arab, is without a reference to it. Ibn Haldûn (see S. de Sacy, Chrest. arab. Vol. I, pp. $1 F y, 1 F v)$, makes the strange statement that the pre-Islàmic noble Arabs abstained from the use of wine, that the vine was not one of the trees cultivated in Arabia and that old and وقو كانت حال :

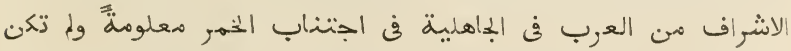

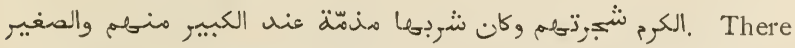
always were, of course, to be found individuals in pre-Islàmic 
time, who abstained from the use of wine and other liquors. But these were rather isolated cases, so f. i., 'Âsad, the son of Kurz ibn 'Âmir ('Ag. XIX, 53, 22). 'Âsad's father "a man of high qualities" was seemingly always well supplied with wine (see, Kais ibn al-Hațîm, ed. Kowalski, XIV, 16-i7). Selfimposed temporary abstinence from wine (and food, women, etc.) is often undergone before starting on the mission of bloodrevenge. Amruul-Kais, at the news of the murder of his father at Demmun in al-Yaman vowed, after seven nights spent in drinking, to abstain from it until he had taken blood-revenge (Kitâb al-'ag̉ânî, VIII, p. 68). 'Abû Kais ibn al-'Aslat swore to abstain from wine for thirty nights (var., years; Kais ibn al-Hațim, ed. Kowalski, IV, 28). Ta'abbața Sharran, after having accomplished his task of avenging his uncle, slain by the tribesmen of Hudhayl, sings ${ }^{1}$ :

"Lawful now to me is wine, long forbidden:

Sore my struggle ere the ban was o'erridden.

Pour me wine, O son of 'Amr'! I would taste it,

Since with grief for mine uncle I am wasted."

Three motives are always recurring. The poet boasts of his drinking powers, mentions his liberality when drunk, and the exorbitant price he paid for the drinking-bout. Yet, the Arab had not always a chance to drink wine. $\mathrm{He}$ was dependent upon the wine merchant, the tarir, who was generally a Jew ${ }^{2}$, and sometimes a Christian. In 'Ag. VIII, 79 the Christians of Hîra are mentioned as being engaged in the sale of wine. Wine was very expensive in all parts of Arabia. In the deathsong of 'Abd-Yaghûth, son of Waqqâs, chief of the Banu-1-Hârith, of Najrân, he sings: "Now am I as though I ne'er had mounted a noble steed, or called to my horsemen - "Charge! gain space for our men to breathe", or bought for a wealth of gold the full skin of wine" 3 . "Amr ibn Qamî ah" XII, 3: "The wine-skin is a kingdom to him who pos-

I) Hamâsa, p. $3^{82} \mathrm{ff}$; translated by Micholson, R. A., A Literary History of the Arabs, p. Ioo.

2) Goldziher, $Z D M G$, Vol. 46,1892, p. 185 . Mufaḍalîyât, ed. Lyall II, 34 .

3) Lyall, Ch. J., Transl. of Anc. Arab. Poetry, London, I885, p. 86.

4) Lyall, Charles, The Poems of 'Amr son of Qâmî'ah, Cambridge, 1919. 
sesses it, and the kingdom therein, though small, how great it is!" 'Abîd VII, 17-18: "We bid up the price of all old wine, strong and fragrant, whiles we are sober. And we hold of no account, in pursuit of its delights, the mass of our inherited wealth, when we are drunken 1." When 'Abd-Yaghûth was taken prisoner and "was about to be gagged, lest he should utter satires against them before being put to death: for he was a famous poet...... then he said - "Ye men of Taim, if ye must slay me, let me die as befits one noble". "And how wouldst thou die?" asked they. "Give me wine to drink, and let me sing my death-song, 'he answered"' 2 .

Mutalammis ${ }^{3}$ describes the wine as his sweetheart ${ }^{4}$, who exercises such a great power over him, that his own volition completely succumbs to his beloved, It has made him lightminded, frivolous. But, finally, he severs the bonds and gives up drinking, after he recognized that fear of god and thrift are after all more profitable. He says, ${ }^{5}$ :

"My heart is frivolous after a period of rest and it is generous in submissiveness to the friend.

I) Lyall, o. c., p. 29; see also 'Abîd XXVIII, 4 (Lyall, o. c., p. 59): "If I drink wine, if I buy the costly juice at its price."

2) Lyall, o. c.; pp. 84 and 85 .

3) See Vollers, Arabische Gedichte des Mutalammis, in BA, Vol. V. Pp. 189-19o and p. 218 .

4) The poet really turns it around and describes his sweetheart as wine. His love is filled for woman as though he is a drinker etc.

5)

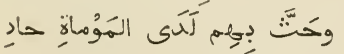

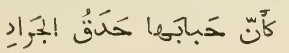

$$
\begin{aligned}
& \text { لما أبَيَا | } \\
& \text { بَشاشةُ كلّ عِلقِ مُسنتَفادِ } \\
& \text { وتَنْوَى اللّهِ من خَيَ العَتِادِ }
\end{aligned}
$$

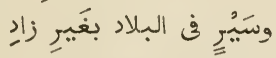

$$
\begin{aligned}
& \text { ولا يَبْقَى الكثيَُّ هع الفَساد }
\end{aligned}
$$

Lutz, Viticulture and Brewing.

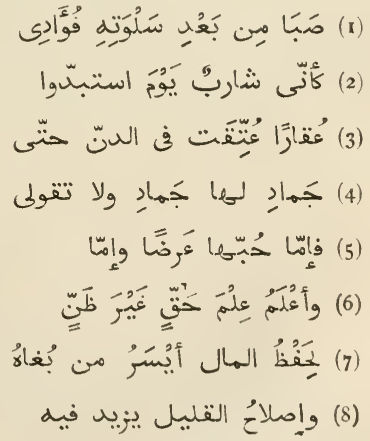

10 
I am like a drinker on the day they go their own way, and the driver rouses them for the departure to the desert,

(a drinker of) wine that has aged in the wine-jar, until the drops of its foam are like the eyes of the locust.

A curse upon it! a curse upon it! And thou shalt never say to it, when it is 'mentioned: Praise unto it! 1

Its love is either non-enduring, or like the joy for every precious thing from which one draws profit.

But (now) I know with absolute certainty, without a doubt, since the fear of god is of the best endowment:

To guard the wealth is easier than to seek it and to wander about in the country without provisions.

A little which is kept in good order multiplies, but abundance does not remain with corruption."

In a second poem the same author thinks of death and the grave and he asks his friends to think of him when he is gone. In this mood he turns back and remembers the joy which he experienced in life. Amongst the pleasures he does not fail to mention also the wine:

"And did not a maiden give him to drink of a well-tasting, agreeable, cool beverage, which the people guard?

And has he not taken a morning-drink of wine, whose fire permeates his members, be the day warm or cold?" 2

'Amr ibn Qamîah'3 deplores his lost youth, in which he often used to sit in the wine-shop, in the following verses:

"O woe unto me for the youth which I miss (I miss in it no small thing!) -

I) A similar sentiment is expressed in 'Amr ibn Qamîah, XII, 6.

2)
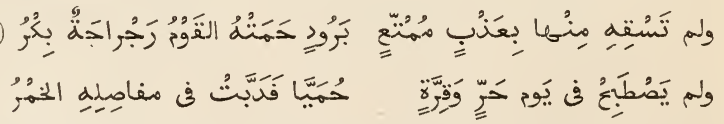

3) 'Amr was a contemporary of Imraul-Qais, with whom he journeyed to the Court of the Greek Emperor Justinian (C. 535 A. D.). He died on the way in Asia Minor at a great age. 
When I trailed my garments of silk and wool to the nearest of my wine-sellers,

And I shook my locks"1.

A slight intoxication was considered as constituting one of life's joy by Sulmî ibn Rabî́ah of Dabbah 2:

"Roast flesh and a slight intoxication

These are life's joy" 3 .

Burdj ibn Mushar of Tai describes his care-free life with his friend in the following song ${ }^{4}$ :

"And many a drinking-companion, who increased the cup's sweet odor, -

I gave to drink, when the stars disappeared.

I lifted his head and removed from him,

With pure wine, the rebuke of him who found fault.

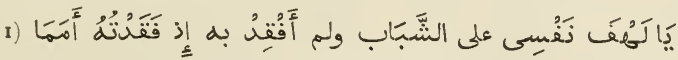

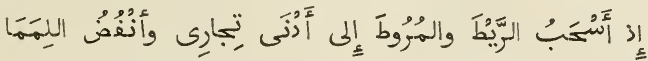

2) He seems to have lived some two generations before Muhammad.

$$
\begin{aligned}
& \text { إِّ شِوَاءًا وَنَشَوَتَ }
\end{aligned}
$$

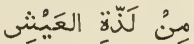

4)

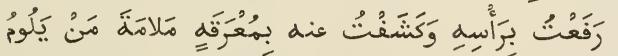

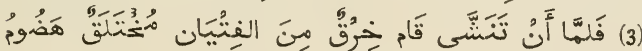

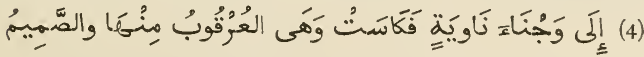

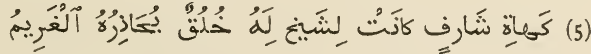

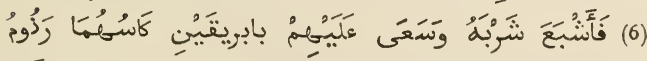

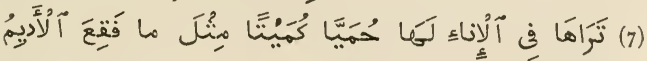

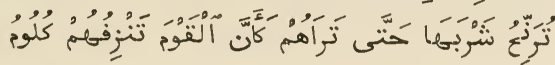


When he was inebriated, he rose up -

The most liberal youth (and) a well-bred lavisher -

Unto a strong and fat camel. It limped

And its knee-joint and tendon was torn;

An old (and) noble (camel) which belonged to a sheikh,

Whose disposition was feared by the creditor.

$\mathrm{He}$ satiated his drinkers and hastened unto them

With two wine-jars; whose cup filled to the brim.

You see it in the vessel having strength, reddish even

As the red goat's skin (of Yaman).

Its drinkers stagger, so that they seem

Like warriors, whom wounds have exhausted."

The wineshop, or tavern, is called hânît. Tarafa, Mu'all. 46: "If you seek me in the circle of the people, you will meet me, and if you hunt for me in the taverns, you will find me" ${ }^{1}$. The hânut which is most generally frequented by a person is called mâlaf, eitó, "the customed, familiar place", i. e., die Stammkneipe, f. i., Kais ibn al-Hajîm, XII, 4. The tavern was most likely a wooden booth, which coula easily be erected and taken down, since these wine-booths were to be found particularly at fairs ${ }^{2}$. In some instances it may have consisted of a special compartment of the bazaar-booth, being separated from the bazaar proper by means of curtains. 'Abda ${ }^{3}$ describes the tavern as a cube $(k a$ ' $b a)$, which was illuminated by lamps. Carpets or rugs with elaborate designs of animals, etc. ${ }^{4}$, were spread on the floor. The Arabs, like the Greeks and Romans, reclined at their. banquets ${ }^{5}$, a custom which was introduced into Arabia probably through Syrian influence. The tavern contained (sometimes) also a table (khizvân), f. i., in 'Abda Mufaḍalîyât XXV, 77, which is a piece of furniture which is otherwise unknown in the Arabic

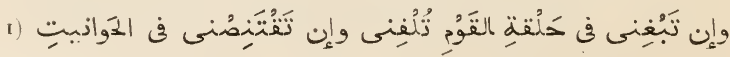
(1)

2) Ibn Hishâm, ed. Wüstenfeld, $43^{8}$.

3) Mufaḍalîyât, XXV, 72 .

4) 'Abda, Mufạ̣d. XXV, 7o. 7 I.

5) Jacob, Georg, Studien in arabischen Dichtern, Heft III, p. Ioz.
} 
household. The Ghassânid king Jabala ${ }^{1}$ sat on a couch of myrtle and jasmine and other sweet-smelling flowers when he would drink wine. About him were gold and silver vessels full of ambergris and musk (Aġânî, XVI, 15 1.24ff.). The wine was served by a waiter, whose finger-tips were colored red with firsìd. He also wore a woman's upper-garment and was adorned with ear-rings ${ }^{2}$. The wine was drunk either from a glasscup (كَ) or from a goblet, called $\operatorname{sahn}($ (ص) a bowl, called qadah ( $\left.\tau^{u}\right)$. The tavern was distinguished by a sign, probably a green branch ${ }^{3}$, which indicated that the wineshop-keeper had still a supply of wine for sale. When the wine had run out, the sign was taken down. 'Antara calls him a gallant man "who causes to be taken down the taverner's sign". Lebîd ${ }^{4}$ sings: "Moreover, you do not know how many serene nights, pleasant in their amusement and mirthful revelry I passed in gay conversation and how many a sign of the wine merchant I went to, when it was raised and the wine had become high in price". The drinking bouts were attended by singing-girls. "My companions are bright as stars, and a singing-girl comes to us at night, clad in a striped robe and saffron-colored mantle" 5 . In A'shâ m. 30 the singing girl (Qaine) wears a wide kimono and is, therefore, called fudul. According to Tarafa $\mathrm{m}$. 50 the singing-girl was by no means bashful. She is asked to sing by calling to her "asmi înâ", i. e. "let us hear". "When we say: 'Let us hear', she steps before us at her ease, gently, in a voice not forced. When she repeates her tones, you would believe her voice to be that of a camel lamenting her lost young" ${ }^{6}$. Abû Mihgan compares her song to the buzzing of flies of the meadow ${ }^{7}$.

I) Jabala was a contemporery of the ruler of Hîra Iyâs ben Qabîṣa of the tribe of Tayyi', who ruled from $602-6$ I $\mathrm{A}$. D.

2) al-Aswad ibn Ja'fur in Mufad̦dalîât, ed. Thorbecke, XXXVII, 23 and A'sha mu'all. 29. The upper-garment is called قartak. Compare with this garment that of the ancient Egyptian butler, p. 84 .

3) See Jacob, Georg, Studien in arabischen Dichtern. Heft I, p. Is.

4) Lebìd, m. 57-58; see also Lebî̀, XII, 20.

5) Tarafa, m. 49 .

6) Tarafa, m. $5^{\mathrm{r}-52 .}$ 7) See Jacob, Georg, o. c., Heft III, p. Io3. 
In 'Antara, m. 23 the song of a man inebriated with wine is likewise compared to the humming of the fly. In Lebîd XVII, 37 the song of the drinker is 'whining'. The singinggirl accompanied her song sometimes with musical instruments ${ }^{1}$. As presents the qaine received the drinker's cloak, which was torn apart in case two singing-girls were present? In the description of the Ghassânid court by Hasan ibn Thâbit (Ag̀ànî, XVI, 15, line $22 \mathrm{ff}$.) mention is made of ten singing-girls, of whom five were Greeks, singing Greek songs to the music of lutes, and five came from Hira, probably Christian girls, who had been presented to king Jabala by Iy'às ibn Qabișa, who was the successor of Nu'mân III. of Hìra. The Hira singing-girls sang Babylonian airs. In addition, Arabic singers were accustomed to come from Mecca. The singing-girls ${ }^{3}$ were disrespected (Diwàn of the Hudhailites, $107,30)$ and prostitutes (Lidzbarski, M., Das Fohannesbuch der Mandäer, Giessen. 1915, p. 97 and 99). For the evil influence of the tavern see, ibid., p. 99: "Einen jeden der in einer Schenke Wein trinkt, sich bei Pauken und Liedern berauscht und in diesem Zustande Unzucht treibt, wird man mit Kämmen von Ketten zerkämmen und er wird seine Augen an Abathur nicht sättigen."

The tavern was often visited during the early morninghours. The morning draught is called sabûh ("َّó). Lebîd, m. 60, 61: "Nany a morning draught of pure wine I quaffed, the singing-girl taking her stringed instrument, which her thumb manages skilfully. I hastened in the early morning before the cock for want of it, that I might take a second draught from it, when the sleepers awoke"t. Kais ibn alHatîim, I, 3: "As often as I take my morning draught, - four

I) See Lebîd, m. 60, 6r; Imr. 63, 5, 6; 'Alqama XIII, 37. For the use of the tambourine (duff) see Gâbir ibn Hunay, Mufadd, XXXV, 9.

2) 'Abda, Mufadd. XXV, Sr; Kitâb al-ag̣ânî. XV, 76 .

3) The omayyade caliphe Yazid II. was completely under the influence of two singing-girls Habâba and Salâma. When Habâba died, he worried himself to death over her loss (Kremer, Culiurgeschichte des Orients, I, p. 150).

4) See also 'Abda, Mufadd. XXV, $66 \mathrm{ff}$. and Tha'laba, Mufadd, XXI, 17, and 'Abîd ibn al-Abraș V, 14 Lyall, The dîwoins of 'Abîd ibn al-Abraș, etc. 1913). 
(cups) - my mi $\approx a r$ draws lines (in the sand) and in generosity I let my pail follow its pulling-rope,"

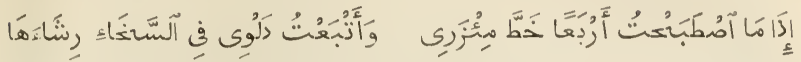

Also $\Lambda$ 'sha makes mention of his early walks to the tavern, stating that he is followed by a zealous, quick and active cook (de Sacy, Chrest. Arab., p. 10r, verse ro). A'sha was buried in Manfuha in Yamama. Revellers were accustomed to meet at his grave and to pour wine over it (Nicholson, R. H., A Literary History of Arabs, New York, 1907. p. 124). 'Antara, m. 37 speaks of the time of the midday-heat: "And I quaffed after the midday-heat had abated, old wine bought with bright and well-stamped coin". Fortunes were squandered in the tavern, on account of the great expense of wine 1 . "When I have drunk", says 'Antara 2, "verily, I am the squanderer of my property, but my fame remains great and unsullied". The generous host is praised even though wine has overcome him (Lebîd XII, 21). Liberality was a characteristic trait of the host. "And if you meet my drinking companions they will tell you that I am the string of a purse, from which I never took refuge in poverty (i. e., by pleading poverty)", Kais ibn al-Hațim, Fr, v, r:

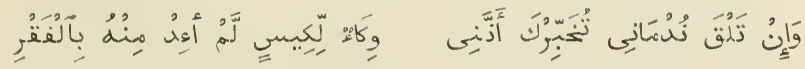

Kais ibn al-Hațim probably reviles the Banû Hàrita in the following verses: "But there are in aš-Šaut some servants from Yathrib, whose price will perish in wine. The al-'Aus consider their price despiceable, when one of their drunkards staggers at evening" (III, 16, 17)

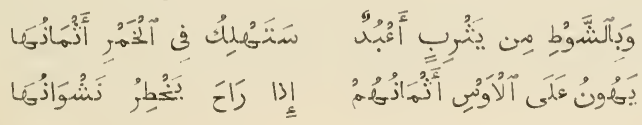

I) The price of a winc-skin tilled with wine was a thrce-year old camel; sce reference in Jacob, Gcorg, Studien in arabischen Dichtern, Heft III, p. 104. Jacob also cites a passage in which it is said that also mares, stallions and slitves were spent in drinking.

2) 'Antara, m. 39 . 
The drinker, in his intoxicated condition, is compared to a male hyaena (Lyall, 'Amr ben Ramîah. XII, 15).

The Nabataeans, who were of the Arabic race, worshipped as their chief-god Dûshara (Nabataean דישריא, Greek

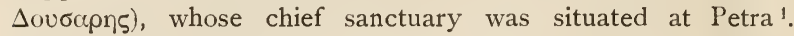
The Classical writers identified Dûshara with DionysosBacchus. The Nabataeans from about the sixth century B. C. occupied the old Edomite country, with Petra as the capital. In history, however, they do not appear before 312 B. C., when, according to Diodorus ${ }^{2}$, Antigonus sent two expeditions against them. In the first century of our era the kingdom extended from Petra northward east of the Jordan over Hauran. Twice it reached even as far as Damascus $^{3}$. In the third century A. D. coins were struck at Bostra

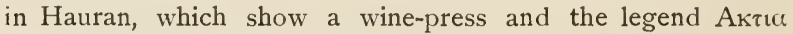
$\Delta$ ovoćpia. Since Petra, as we have seen above, cultivated the vine extensively, it is altogether possible to suppose that the Bacchic character of Dushara is original and that he did not change from a solar deity to that of a Nabataean Dionysos ${ }^{4}$. Gods of Bacchic character are otherwise unknown in Pre-Islâmic Arabia.

In a Palmyrene inscription (Littmann, E., Sem. Inscr. p. 70 $=$ Ephemeris 1,345$)^{5}$ appears the god Saic al-Kaum, who seems to have been worshipped by a group of Nabataeans in opposition to the cult of Dushara-Dionysos. The votive inscription reads in lines 4 and 5: "to Sai" al-Kaum, the good and

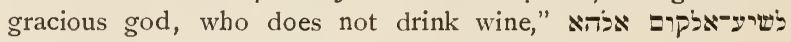
טבא ושכריא די לא שתא חמר

We may finally mention the old tradition concerning the destruction of the peoples of 'Ad in the Hadramaut, in which wine and two famous singing-girls play an important part (Tabari, Annals, I, $231 \mathrm{ff}$.). The.'Adites were of great stature

I) See Epiphanius. Haer. 1. 22.

3) In 85 B. C. and about $34-62$ A. D.

4) For wine-prohibition amongst the Nabataeans see Diod. NIX, 94, 3 .

5) See also Dussaud, René, Les Arabes en Syrue ar'ant l'Islam, Paris, 1907: Clermont-Ganneau, Rec. d'arch. or., IV, p. 382-402, and Wellhausen, Götting. gelehrte Anzeigen, I902, p. 269. 
and strength. They committed all sorts of evil deeds. Finally God sent the prophet Hud un to them. to preach repentance. The 'Adites, however, disregarded the warning of this messenger of God and answered: "O Hud, thou hast brought us no evidence, and we will not abandon our gods for thy saying, nor will we believe in thee. We say: 'One of our gods has afflicted thee with madness"' (Koran, XI, 66, 57). The divine punisment at last overtook the evil 'Adites. A fearful draught fell upon the land. A number of 'Adite chiefs were sent to Mecca to pray for rain. Mu'âwiya ibn Bakr, an Amalekite prince sent his envoys on their arrival to the city and he received the 'Adites hospitably. They were entertained by him with wine and music. Two famous singing-girls, known as al-farâdatân, took part in these entertainments. For an entire month they neglected their mission. When they, at last, executed it, there appeared three clouds in the sky, one red, one black and one white. However, by choosing the black cloud ${ }^{1}$, they brought about the destruction of their people, for God drove the cloud unto the land of 'Ad and from it issued a roaring wind. which consumed all the people, except a few who had listened.

The prohibition of wine-drinking by Muhammed brought about a great change in the attitude towards wine and other intoxicants. This prohibition was never felt to be very severe in a country, such as Arabia, since wine was always expensive and often difficult to procure. And in Syria, the chief wineland of the Orient, it never vitally affected the culture of vine, on account of its strong Christian and Jewish population, while amongst the Persians the new conquering religion of Islàm very seldom took a great enough hold on the people in order to break them away from the customs of their wine-growing country. The prohibition of wine in Surra V, 93 is stated as being due to the fact that Satan causes dissentions in the congre-

1) The 'Adites quite naturally choose the black cloud, sfnce it was con-

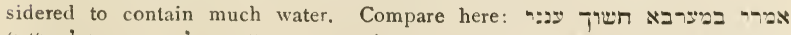

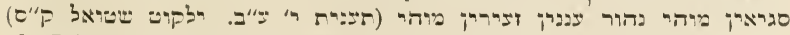
"In Palestine it is said: The dark clouds contain much water, the white clouds contain little water." 
gation through wine and gambling. But this is, however, not the real cause which induced Muhammed to introduce his injunction. Palgrave ${ }^{1}$ held that "the strongest arguments would lead us to assign it, with considerable probability, to the Prophet's antipathy to Christianity, and to a desire to broaden the line of demarcation between his followers and those of Christ." "Wine" he proceeds to say; "has, in fact, been not only tolerated by the Founder of Christianity; but even, if I may so say, patronized, and raised to a dignity of the highest religious import; nay, in the belief of three-fourths of the Christian world, absolutely supernatural. Close on its religious and mystical use follows its social quality and among all nations who own, in Eastern phrase, "the Gospel for their book", that is, are Christians in the most comprehensive sense of the term, wine has always been in high favour, the accompaniment of civilization, of friendship, of cheerful and elegant life, of social, domestic, even of political union, and in this view has been everywhere greatly esteemed and largely employed. This Mahomet well knew; his Greek neighbors alone, with whose ways and customs he was by no means unacquainted, might suffice him for a good example of the fact. Meanwhile his seer-like sagacity, in which he had few equals, led him to anticipate from the Christians far more dangerous opponents, and a more lasting and more perilous hostility than whatever might be expected from Jews or Persians; and at the same time the prudent and almost respectful toleration which numbers and strength exacted, rendered pre-eminently necessary the estabishment of distinctive nay disjunctive marks, calculated to maintain his followers in a permanent antagonism with those whom they could not lightly- despise, nor yet securely persecute. To declare the social, the sacred liquor which had become well nigh typical of Christianity, and in a manner its badge, "unclean", "an abomination". and "the work of the devil", was to set up for his own followers a counter-badge, equally unmistakable and irreconcilable, of a nature to last through all time, of daily occurence, and of equable application in the mosque that antithesis of the sanc-

I) Palgrave, W. G., Central and Eatern Araja. Vol. I. p. 425. 
tuary, and in the harem that contradiction of the house." Palgrave really ascribed to the prophet greater wisdon and insight than he actually possessed. Historical evidences also would point to another direction. Since the law falls within the time, when Muhammed was engaged in a warfare of extermination of the Jews, i. e., in the fourth year of the Hedjra, during the campaigne against the Jewish tribe Nadir, it is probable to suppose that this law was primarily directed against the Jews, in order to undermine their flourishing wine-tracte in Arabial. During the earliest period of the new religion prohibition was strictly observed, although it was not always easy to enforce the law on unwilling Arabs. In Mas'ûdî, Murûg edhdhahab VI, $153^{2}$ it is said of the tribe Garm: "They did not drink it, when it was permitted, and did not raise its price in the market-day, but since the prohibition of wine has come from heaven, behold no Garmî is sober anymore".

Under the Omaiyades a tolerant attitude was taken towards the wine-prohibition ${ }^{3}$, but the ' $\Lambda$ bbâsides introduced a stricter enforcement of the law. Transgressors were threatened with severe punishments, which, however, had not always the desired effect. Already Omar II. was forced to issue a special order prohibiting the use of fermented wine, but allowing the use of $m \hat{a} z e b \hat{\imath} b$ and date-wines. In South-Arabia the muslims continued to drink the mis r-beer as well as their national beverage of honey-wine (bit also called mâdi). The lower classes in the Irak continued to drink date-wine, and sakar,

I) This view was first expounded by Georg Jacob, Stud. in arab. Dichtern, Heft III, p. 106.

2) Cited after Jacob, o. $c_{,}, \mathrm{p}, \mathrm{x}, \mathrm{7}$.

3) At the court of the Omayyades in Iamascus wine-drinking was introduced by Yazid I, of whom it is said that he intoxicated himself daily and that he hardly ever was sober. Abdalnialik drank wine once every month emptying his stomach by means of emetics, in order to be well again next morning. His son Walid I. drank wine every second day. Walid II. spent most of his time in the circle of musicians, singers and his drinking-companions. When in I Iо a. H. his uncle IIishâm appointed him leader of the pilgrim-caravan to Mecca, he entered Mecca with great pomp and even desired to have his tent erected on the roof of the Kaaba, in order to carouse therein with his drinking-companions. 
which was prepared from dried dates and addition of bitter herbs and myrrh. The court-poet Abû Nowâs frequently mentions the khumar, the effect of excessive drinking, in his winesongs." When, in time, a stricter application of the prohibition had taken place among the people, other narcotic and stimulating substances came more generally into use, as, for instance, the chewing of the leaf of the kâdi-shrub (catha edulis), a plant which grows only in South-Arabia, and the consumption of coffee. 


\section{Index}

A

Abel keramim, 25.

Absinthinm Is.

abstinence, tempory 14.

Abyssinia, wine-import inte 23.

Adum $1+1$.

'Ain-Kushith, wine of 2).

Alashiva $20,2+$

alcoholism, chrouic 1,0 .

Aleppo 23. 42.

Alexandria :t

Alt, city of : 0

Ama-gestin, soddess 1;1.

Amedi, city of +4.

Amminea if.

"Aur ibn Camitah 1fo.

Ant, wine of, see lemet.

Amurru if.

' 212.

'Ana, wine of t3.

Anit), 25

'Auifit, vineyards of :

'rut-mer 50.

Androtn, wine of 24.

arequalles $32,+5$

Aataens 114 .

Autarimius 20, 05.

anthesteria, ntes of the 113.

Anthylla, wine of + .

Apanea, witue of $: 3$.
Apple-wute is

Arab-1).ugh +s.

Arabia, vituerards of $\therefore$.

- wille of 30.

- witte export trum ifo

-. wine import inte it. 31,45

Aramabum, country of $+k$

Irbailu +1, + 2 .

Arsincitic nomos, wine of 2 , 0

Artificial wine 10, 1\%, 10.

'Artuti or,

Arral, witue of $: 2$.

Aranbiat moumtain of 3

Arantrina $+1,+2$

Asalli, country of +3

Ascialon 3.5

"Ashbeer - n. 1

assistunt wine master (n), 70,71

Assi ria, viticulture of 35 .

Athitit, in al- launan :3

"Atiyg, mathallat ale, of Bagdid

(3).

\section{B}

Balbek, wine of it

Bant-Hamon 2 .

liabylouia, beer of +1 , so.

- viticulture of $3 \%$, is

- witre of 35

-, wine-export ti 
Bağdâd 39, 40.

Bahr al-Mashra' 15.

Bahrain 43.

Bahriye, oasis of 14 .

Bait Ras, wine of 24 .

Bakuba 39.

banquets, Assyrian 118, 119.

-, Arabic 148.

-, Hebrew 137. 138.

baqa 18.

barley $74,75,76,78,79,81,82$, $86,89,92,110$.

Barygaza 34 .

Bata' 33 .

beer, in Arabia 93, 94, 95, 96.

-, in Babylonia 41, 86.

-, in mythology 110.

-, Nubian 72.

beer-house 69, 105, 108, 110, 127 .

-, keeper of $[a \cdot k a s ̌ l u b=$ šâkû] 70.

beer-loaves $81,86,89,90$.

beer-mash 81 .

beer-tax 85 .

"beer which does not sour" 77 . "beer of eternity" 77 .

"beer of the goddess Maat" 77 .

Belîh 43.

Berytos, wine of 32 .

-, coins of 141 .

Bês, god 114 .

Bêth Hakkerem 25.

Bêth Laban 26.

Bêth Rima 26.

Bezek, wine of 29.

Bilgai, stele of 20 .

Biq'ath bêth Kerem 25.

Birath Sariqah 29.

Bireǧik 42.
Birtu 41, 42.

Bît-Adini 43 .

Bît-Kubatim 43 .

Bitâtu 43.

bitumen 56,81 .

Bît-Zamâni 44 .

black beer 88 .

Bœotia 1.

Book of Proverbs 135.

Borgatha, wine of 29 .

Bosrâ, wine of 24 .

Bostra, coins of 152 .

bottles, beer- 81 .

Brewers 70, 72, 76, 85, 86, 89,

$90,92,93,116,120,127$.

brewery $76,87,93,126$.

"brier"-wine 31 .

Bubastis 2, 107.

Butâmu 43.

butler 84, 85, 120, 121.

Byblos, wine of 31 .

\section{C}

Caesarea, wine of 23.

Cairo 5 .

Cana, of Eleazus 16 n. 3.

Carchemish 44, 70.

cardamom 94.

carob 9, 10.

catha edulis 156 .

Cathif, grapes of 34 .

Caucasus 1.

Chaibar 35.

Chalybon 22, 31 .

Chătulim, wine of 26 .

chief wine-master 69,70 .

Chios 1.

cinnamon 94 .

clapping, of hands 53,54 . 
clay-barrels 68 .

clove 94.

City of the Apis-bull 12.

Code of Hammurabi 128, 134, 138.

- of Justinian 32 .

coffee 156 .

consumption, of beer 85 .

-, of wine 115 .

conversations, at banquets 100 . cuscuta 31.

cup-bearer, see butler.

Coptos, wine of 4,14 .

Crocodilopolis-Arsinoë 2.

custom-house 20,41 .

-, official of the 20 .

,$- \operatorname{tax} 45$.

\section{D}

$d a b$-wine 18 .

Dâdiyy 95.

Dair al-'adârā, wineshops of 39.

Dair al-'Alt, wineshops of 39.

Dair az-Zandaward, grapes of 39.

Dair Darmâlis 39.

Dakhel, oasis of 13,14 .

Damascus 22, 23, 36, 43 .

Damr, grapes of aḍ - 35 .

Daphnae 16.

dark beer, 72 .

dark wine 9,36 .

date-wine $17,31,35,41$.

day of drunkenness 107 .

dbw 9 .

$d b y(y) . t 18$.

Delta 2, 10, 15, 20.

Dendera 112.

desert, Libyan 13.
| Diyàr-Bekr 44.

Dionysos 2, 113, 114, 115, 140, 141,152 .

Diospolis parva 13 .

dnrgs 9.

dracunculus hortensis 94.

drinking-bouts $98,100,106,138$.

drinking-custom $139,140$.

drinking-tubes 140 .

drinking-vessels 133,143 .

drunkenness 10, 35, 97, 98, 100,

$108,115,133,134$.

durra-beer $77,78,95$.

Dùshara 152 .

Daha, the presses of 22 .

Dsds, oasis of 10,17 .

Dshendale-grape 64 .

dwy-beer 74 .

\section{E}

East Africa, wine-import into

23, 31 .

Ecboladic wine 4.

Edom 152.

Egypt 1, 2, 5, 6 etc.

Elephantine 14, 110.

Eme-te, god 132.

Engedi, vineyards of 28 .

Esmun, god 141.

Esna 7, 10.

Ethiopia 110.

Etolia 1.

Euphrates 42, 43 .

Expense, of wine $137,144$.

\section{$\mathbf{F}$}

Fall-festival 65 .

Fayyûm, vineyards of the 2, 6, 7 .

Fenhu, wine of the 33 . 
fermentation 54,56 .

-, vat 80 .

figs 17,25 .

fig-wine 9,18, to.

filtration, of wine 56 .

fity-beverage 24 .

fokka 93.

foreign wines 16,20 .

frankincense 23 .

"Friends"-beer 73 .

funerary wine 56 .

\section{G}

Galilee 29 .

Garm, tribe 155 .

Gath, viticulture of 29.

Gath-Hahêfer 29.

Gath-Rimon 29.

Gaza 16, 32.

G'abal akhdar, in 'Oman 34.

Gennesaret 26, 29.

G'enwàn, grapes of 34 .

Geštin, goddess 131 .

ghobairâ 95.

Gilgamesh 131.

G'izah, vineyards of 6 . gods of inebriating liquors 132 .

G'auf, viticulture of the 35 . grapes $3,4,6,8,9,14,23,24$, $25,29,33,34,35,36,38,39$, $40,50,51$ etc.

grape-juice 54, 56, 65.

Greece, wine-export of 16, 20, 22.

Gurgum, country of 43 .

Gurumu 42.

Guzana 41,42 .

\section{H}

h3zwh.t 9, 74 .

Habur, mountain 38 .
Hàbùr, river $+2,+3$.

hag Iahweh 64.

Hầil, vines of 36 .

Halziadbar 41, 42 .

Hamrîn-mountain 39.

harp-player 103, 104.

Harrân, vinestalks of 40 .

Haru, wine of 26 .

Hathor, inventress of beer 111 .

-, patron goddess of wine 112.

Hat-seha-Hor, produce of 10.

Hat-u $r$-imnt, produce of 8 .

Hauràn, wine of the 24 .

Hawàli, river 40.

Hazàz ('Azàz) 43.

hbt-beverage 74 .

Hebron 25.

Heliopolis 19, 111.

hellebore 18.

Hemy-wine 13 .

Heracleopolis, vineyards of 14 .

Herb-wine 28.

Heroonpolis, viticulture of 14 .

hes-beer 72 .

Hihi, mount 38 .

Hilbunum 43.

hîlîston 26.

hinway $a$-beverage 74 .

Hî̀a $144,150$.

hk.t 74,77 .

hn-'-beer 72 .

hns'm-beer 72 .

hômez 30.

Homs 32.

honey 88,91 .

honey-wine 28,33 .

hops 75 .

horteum hexastichum, L. 74

-, tetrastichum, Kche. 74. 
Horus 114.

K

Horus-eye, the green 7 , 8, 59. Kab, al- 15 .

- the white 8 n. 2 .

"bouse of drunkenness" 111.

$h t-h s p . t 14$.

Huneb, god 15 .

Husur, river 42 .

hwe t-beer 73 .

\section{I, J}

Iacobite Christians 39.

iynbu 24.

'Imet 11.

'Imn.t, nomos of 12 .

import, of wine, into Egypt 16. -, of beer, into Egypt 82, 83. incantations 130.

India 23,31 .

inn-keepers 106, 128, 129, 130, 137.

inspector, of brewery 84 . inspector, of wine test 58 .

'Irâq 39.

irrigation 49.

iron-beer 72 .

irp 7, 9, 10.

irp-zos 8.

irp-im.t 11.

irp-h:m 11 .

irp-rs 10.

irp-mh 10.

irp-sin 11.

Isana 41,42 .

it 76 .

Izallu, country of 43 .

Farâdatân, al- 153 .

Jemnuti, city of 4 .

Jericho 68.

Joppa, vineyards of 32 .

Lutz, Viticulture and Brewing.

$k \hat{a} d y$-leaves 156 .

Kaine, customhouse of 21 .

Kaish, island of 34,

Kalah, vineyards of 38 .

ka-n-kemet $15,48,58$.

Kanțara, la- 16.

Kara Âmid 44.

Kašiari-mountain 44.

Kasius, mount 16.

Kaš-tin-nam, goddess 132 .

Kĕfar 'Azîz, vineyard of 26.

Kĕfar Pagesh 29.

Kĕfar Shalem 29.

Kĕfar Signar, wine of 26 .

Kerzûn 42.

Khargeh, oasis of 13,14 .

Khuss, wine of al-24.

Kîmân Fâris, mounds of 2.

knm.t, of Diospolis parva 13.

knm.t, oasis of 10,17 .

Koran 35, 153.

kurunnu 41, 117, 119.

$k \hat{u} s h \hat{\imath} 27$.

Lachish, vines of 26 .

Lake Mareotis 3, 12.

Laodicea, wine of 16,23 .

laurel-tree 30 .

laurus malabathrum 31.

laws, regarding drunkenness 134 .

- , regulating sale of beer 128 , 129.

Lebanon, wine of $23,29$.

lemon tree, leaves of the 94 .

Libyae nomos 12 .

Lot 29, 134 . 
lotus flower 98, 99.

Love-poetry, Egyptian 108. lupin 75 .

luxury, at banquets 137 .

M

$m \hat{a} z e b \hat{b} b 37,155$.

Ma'arrah an-Nu'màn 24 . mâdi 155 .

Maganuba, vineyards of 43 .

Maioumas, harbor of 32 .

Malaga, in Spain 66.

malt 88 n. 4,89 .

mandrake 110 .

Mar'ash 43.

Marea, wine of 2, 3, 5 .

Margat, wine of 29 .

Maryûț 3.

Maron, companion of Dionysos 3 .

Marqasi 43 .

Masius, mount 44 .

Masqat 34 .

mastix 94 .

Me-azag, god 132 .

Mecca 34, 150, 153.

Medina 35 .

Memphis 2, 16 .

Mendes, wine of 4 .

Menqet, beer-goddess 113 .

Meroe, viticulture of 4 .

Mesopotamia, vines of 38 .

Miniet ibn al-Khașib, vine of 6 . mint 94 .

mixed wines 18,41 .

mizr, mizar, Arabian beer 95 , 155.

$m n$-wine 9.

morning-draught 150 .
Mutalammis 145 .

mulsum 23.

muscatel grape, original home of 34 .

musk 94, 149 .

must 24,78 .

Muza, in South Arabia 33.

Mykerinos 2.

myrrh 30 .

myrrh wine 30 .

myxa 17.

\section{N}

Nabataeans 152.

Nahal Eshkôl 25.

nahlayn 58 .

Naphtali 29.

Nasiraeans 133.

Nebesheh 11 n. 1. 14.

Negeb 62 .

Nestorians 39.

Nh3mme, wine of 12,13 .

Nham.t, city of 14 .

Nineveh 38, 44, 45, 69, 126.

Nin-Kasi, goddess 132 .

Nin-mada, goddess 132 .

Nin-til, goddess 132 .

Ninua 39.

Ninurta, god 132.

$n m \dot{s}$. $t$-beer 73 .

Noah 134, 142.

noon-day draught 151 .

ntr-beverage 74 .

Nubia 2 n. 1, 6.

Nulia 43.

nunneries, wineshops of 39 .

Nu-silig-ga, god 132 .

nutmeg 94.

nwt-nt-Hapi 12. 
Nysa, in Arabia 33.

- in Phoenicia 31.

\section{0}

Oasis, the northern 13. 14 .

-, the southern $13,14$.

Ogdor, wine of 29.

oinomeli 28.

olive 25 .

'Oman, viticulture of 34 .

Orontes, valley of the 23 .

Osiris 2, 113, 114 .

Ostracine 16.

overseers, of wine-cellars 68 .

"ox-eye"-wine 41 .

\section{$\mathbf{P}$}

Pa-geštin-dug, god 132 .

Palestine $18,24,25,26,31,36$, 61,64 etc.

palm-wine 35 .

Pa-mer 3 .

Pa-merti, district of 3 .

Pangeum 22 n. 2.

Paraetonium 12.

parsley 94 .

Patin, country of 43 .

Pelusium 10, 13, 14, 16, 17, 76.

Peparthian wine 5 .

pepper 28, 94.

Per-Ramses-Mery-Amon 15.

Persia, wine-import into 22.

Pĕrûgîtha, wine of 26.

Petra, vineyards of 34,152 .

peuce 4 .

ph-beer 72 .

Phoenicia 16, 30, 31.

Plinthinic wine 3 .

przw-beer 73 . poetry, pre-islamic $143,144$.

pomegranate-wine $9,13,15$,

$17,18,30$.

Pontus, wine of 5 .

pressed wine 41.

pressing-vat 53, 66, 130 .

priests, Babylonian 123 .

priests, Egyptian 2, 107.

prima beer 89 .

prohibition, of wine-drinking 153.

props 63 .

psythia 27.

ptry, canal 15 .

Purim 107.

pûra 66, 67.

Pyramid-texts 10.

py'rgos 62.

\section{Q}

Qàdesia 24.

Qasirin 24.

k. $3 y$ y 8.

ken' $n) y$-beverage 24 .

Qenqen-tane 83 .

Qèruchim, wine of 26.

Qode-beer 82, 83, 84.

Quțrabbul, wine and wineshops of 40 .

R

raisins prohibition of the sale of 5 .

raisin-water 37 .

Raphia 16.

Rashid 6.

recipes, beer- $78,81,89,91$,

93, 94.

red beer 89 .

red wine 7,36 . 
Rekhabites 133.

Rephaim, wine of 29.

Resheph, god 114 .

Rome, beer export to 76 .

-, wine export to 3,5 .

resin 56.

Rhinokorura 16.

Rimusu 42.

Ror 65.

rue 18,94 .

\section{S}

รัง $7,46$.

รั3-imn 12.

$\Sigma^{3} 3-m n ! 212$.

s3mw-beer 73 .

šsiz 7 .

Ša-bil, goddess 132 .

Sâbu, moünt 132 .

śaj 11.

sacrificial offering of beer and wine $111,125,126$.

Sadjur 42.

Sadûm Ràh 35 .

safflower-seed 82 .

Śai' al-Ķaum, god 152 .

Șàlihị̂yeh, aṣ- 11 n. 1, 16.

salt 82 .

Samaria 29.

Sâmarrâ, vineyards of 40 .

Șan'à 33, 34 .

Sarepta, wine of 32 .

Śariš, city of $41,42$.

Sarkhad, wine of 24 .

Sharon, plain of $25,26,62$.

Sarugi (Serûǵ) +3 .

sathîy, the 139 .

Sawiq 95 .

šbb.t 9 . šdh $9,17,18$.

śdw-ib 8 .

Sebennytic wine 3,4 .

sehpet 72 .

šêkhar 93.

Seleucia, wine of 24 .

šft.t 13 .

Shedet, city of 2 .

Shesmu, constellation 114 .

Shibàm, mount of 34 .

Shîlo 26, 64 .

shoots 63 .

Sicily 31 .

Sidon, wine of $26,29$.

- , coins of 141 .

Siduri, sâbîtu 130, 131.

sign of wineshop 138, 149 .

sikkôr, the 139 .

ŠIM+KAŠs, goddess 132 .

ŠIM + KAŠ-gig, goddes: 132 .

Simminu, country of 43 .

șimûqîm 27.

Singara, vinestalks of 40 .

singing-girls, Hebrew $137,{ }_{1} 8$. singing-girls, Arabian 1 149, 15o,

152.

siphon $19,67,68,139$.

Siris, goddess 39.133 .

skirret 75 .

slough, linen $54,55,56$.

s'mh-beverage 74 .

"smoked" wine 27 .

Sohet, vineyard of 8 .

sokorkah 95 .

Somali Coast, wine import to the 23 .

South Arabia, wine import into 23.

Spain 31. 
spelt $76,79,86,89$.

spiced wines 18,30 .

srt 76.

storage, of wine 58 .

Sûhu, country of 43 .

Sulmî ibn Rabîah 147.

sumach 25.

Sûnâyâ, grapes of 39 .

superintendet,of the vineyard6o.

Susa 40.

sweet beer 73 .

sweet wine $15,26$.

Syria 16, 20, 22, 24, 26, 31, $32,36,37,153$.

\section{T}

tâabatu-wine 41 .

Tabuke-grapes 64 .

Taeniotic wine 3 .

Taiâ 43.

TTầif, grapes of aț- 34,35 .

Tamnuna, city of 41,42 .

Tanis 15 .

tavern $127,128,129,137,148$, 150,151 .

tax, for vineyards 60,61 .

Tbui, district of 14 .

Tell Defenneh 16.

Tell al-Kaāṣr 4.

Tell Roba 4.

Tenemet, goddess 114 .

Thasian grape 3,4 .

Thebaïs, wine of the 4 . th 9 .

"Three-leaf"-wine 27 .

Tiberias, sea of 65 .

Tilabnê 43 .

tinrekw 9.

Tmei al-Amdid 4. toast, Egyptian 102.

Trace, moutains of 1 .

transportation, of wine 17 .

tribute, wine- 22 .

Tripolis, wine of 32 .

Tu'immu, country of 43 .

Tûr-'Abdîn 44.

Turkestan 1.

Tylos, island of 34 .

Tyre $1,16,22,26,31$.

-, coins of $1+1$.

\section{U}

'Ukbarâ, grapes of 40 .

Upper Egypt, wine of 4 .

-, vineyards of 13,14 .

use of wine, in Palestine $133 \mathrm{ff}$.

\section{V}

vats 53,54 .

vine $1,6,14,22,23,24,25$, 26 etc.

"Vinebearing Region of Amon"

12.

vine-city 114 .

vinedresser 49, 62, 66 .

vinegar 5,30 .

vinegod 132 .

vine-goddess 131 .

vineyard $2,6,8,13,14,15,21$ etc.

vintage $50,52,53,64,65$.

vintage-festival 64,107 .

vintner 68 .

vinum conditum 28 .

vinum culpatum 30.

vitis labrusca, L. 28.

vitis Schimperi 5.

vitis viniferd 1. 


\section{W}

wâdi Dahr 33, 34 .

waiter, Arabian 149.

warning against drunkenness $105,108,137$.

wheat $79,82,86,94$.

wine-god, Hittite 141.

"White Wall", near Memphis 48.

white wine 7 .

wicker-baskets 51 .

wine, price of 139,151 .

-, mixed with rain-water 36 .

-, in mythology 111, 130, 131.

-, new 136.

wine-cellar $7,15,58,59,68$.

wine-wharf 127 .

wine-cups 119, 120 .

"Wine-district", the 14 .

wine-drinking, in Arabia 143.

wine-jars $16,32,47,58,68$.

wine-labels $57,58,69$.

wine-lees $54,56,57$.

wine-merchants, in Arabia, 144.

- Phoenician 16.

wine-must 9 .

wine-offering 19 .

$[62,66$.

wine-press $33,51,53,54,55,56$, wine-presser $53,66,68,71$.

wineshop 39, 69, 105, 127, 128, 148.

wine-skin $36,57,68$.

wine-tax 20, 21, 68 .

wnš $8 \mathrm{n} .1$.

\section{Y}

Yaa, in Syria 22.

Yahweh 133, 134, 140, 141.

Yaman, wine of al- 33 .

yayin 28.

yeast 75,79 .

yeast-wine 67 .

Yemet, wine of 11 .

yeqeb 66, 67.

Yisreel, plain of 62 .

Yusur 24.

\section{Z}

Zab 42.

Zaban, city of 42 .

Zanet, city of 15 .

Zeb-nuter, city of 4 .

Zembûr 42.

Zoan, city of 15 . 



\section{PLEASE DO NOT REMOVE} CARDS OR SLIPS FROM THIS POCKET

UNIVERSITY OF TORONTO LIBRARY 
